\title{
DE ONTWIKKELING VAN HET CHONDROCRANIUM VAN ALYTES OBSTETRICANS VOOR DE METAMORPHOSE
}

\section{$59.78 \cdot 14.71,4$}

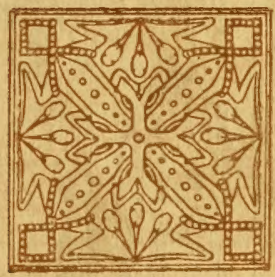

W. H. VAN SETERS 


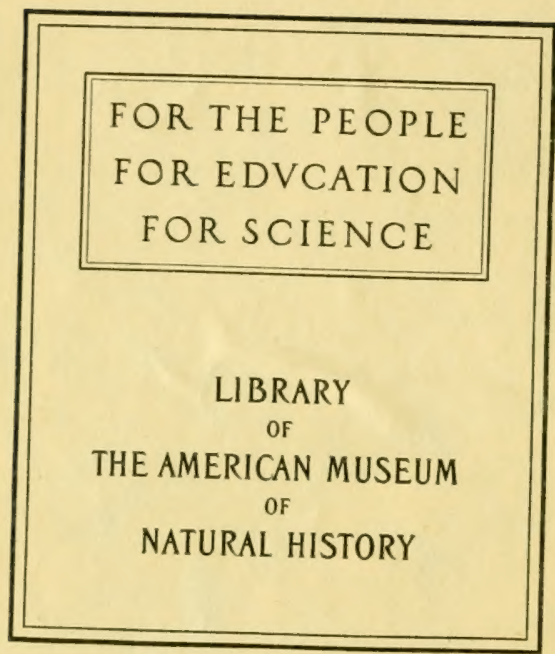





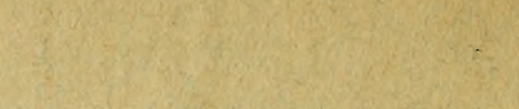


Deontwikkeling vanhet Chondrocraniumvan Alytes obstetricans voor de metamorphose 


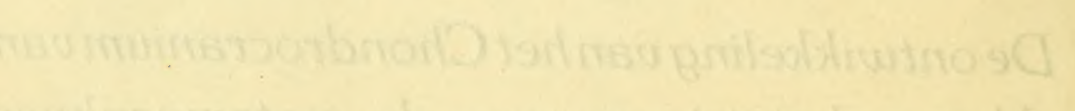

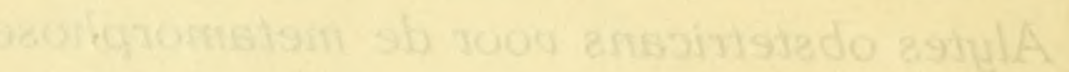




\section{DE ONTWIKKELING VAN HET CHONDRO.}

CRANIUM VAN ALYTES OBSTETRICANS VOOR DE METAMORPHOSE

$$
59.78: 14.71
$$

PROEFSCHRIFT TER VERKRIJGING VAN DEN GRAAD VAN DOCTOR IN DE PLANT - EN DIERKUNDE AAN DE RIJKS-UNIVERSITEIT TE LEIDEN, OP GEZAG VAN DEN RECTOR MAGNIFICUS R. P. VAN CALCAR, HOOGLEERAAR IN DE FACULTEIT DER GENEESKUNDE, VOOR DE FACULTEIT DER WIS- EN NATUURKUNDE TE VERDEDIGEN/OP VRIJ DAG 11 MAART DES NAMIDDAGS TE 3 UUIR,

\section{DOOR}

\section{WOUTER HENDRIK VAN SETERS}

GEBOREN TE 'S-GRAVENHAGE

DRUKKERIJ „HET KLAVERBLAD”, 'S-GRAVENHAGE 


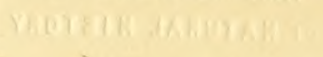


Aan mijne -Ouders 


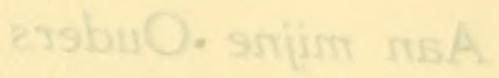


Het verschijnen van dit proefschrift biedt mij de welkome gelegenheid U, Hoogleeraren der Philosophische Faculteit, openlijk mijn hartelijken dank te betuigen voor het onderwijs, dat ik van $U$ mocht ontvangen.

Het is mij een aangename plicht in het bizonder U. Hooggeleerde Van Kampen, te danken voor de bereidwilligheid, waarmede Gij als mijn Promotor wildet optreden. De wijze, waarop $\mathrm{G}_{\mathrm{ij}}$ steeds bereid waart mij bij de bewerking van mijn onderwerp ter zijde te staan, de blijken van belangstelling, die ik zoo dikwijls van $U$ ondervond en bovenal $U w$ vriendschappelijke omgang mogen hier door mij met groote erkentelijkheid herdacht worden.

Uwe belangwekkende colleges, Hooggeleerde Janse en Martin, zullen evenals de tijd, waarin ik onder Uwe leiding practisch werkzaam was, steeds bij mij in aangmame herinnering blijven.

De vriendelijke voorkomenheid, warmede Gij, Zeergeleerde De Graaf, mij steeds tegemoet zijt getreden en de bereidwilligheid, waarmede Gij mij met $U_{w}$ groote technische ervaring hebt willen voorlichten en inwijden in de geheimen der zoötomische onderzoekingsmethoden, geven $\mathrm{mij}$ in het bizonder reden tot groote dankbaarheid.

Door Uw mikrotechnischen cursus, Zcergeleerde Droogleever Fortuyn, heb ik 'ook aan UI in dit opzicht zeer veel te danken.

Ten slotte ben ik allen, die nij op eenigerlei wijze bij de samenstelling van dit proefschrift van dienst waren, groote erkentelijkheid verschuldigd.

In het bizonder geldt dit U, Hooggeleerde De Jong, die mij op Uw laboratorium in de gelegenheid stelde de benocdigde mikrophotografiën te vervaardigen.

Mijn laatste woord zij aan de nagedachtenis van mijn hooggeachten Leermeester, wijlen Professor Vosmaer, gewijd, wiens uitnemend verzorgde colleges en practica ik steeds dankbaar herdenken zal. 



\section{Inleiding.}

Het vergelijkend onderzoek naar de ontwikkelingsgeschiedenis van het chondrocranium bij vertegenwoordigers van een bepaalde klasse der Vertebraten zal eerst dan tot zijn recht komen, wanneer het zich kan uitstrekken over zooveel mogelijk verschillende vormen.

Herhaaldelijk valt echter het verschijnsel te constateeren, dat men, om begrijpelijke redenen, zich bepaalt tot die species, waarvan men, door het veelvuldig voorkomen in een bepaald gebied, steeds over de noodige en gewenschte stadia beschikken kan. Een schaduwzijde van dit begrijpelijke streven is, dat de aandacht van verschillende onderzoekers zich onwillekeurig steeds weer op dezelfde vormen richt.

Het onderzoek omtrent het chondrocranium der Anuren geeft hiervan een duidelijk voorbeeld.

We komen in de literatuur steeds weer in aanraking met Rana, in het bijzonder met Rana fusca. Door de onderzoekingen van Parker (1871), Stöhr (1882), Gaupp (1893) en Peeters (1910) is de ontwikkelingsgeschiedenis van dit chondrocranium steeds beter bekend geworden. Hunne onderzoekingen hebben elkander op voortreffelijke wijze aangevuld. Stöhr onderzocht de allerjongste stadia van den eersten prochondralen aanleg af tot het begin van kraakbeenvorming; Parker en Gaupp gingen de ontwikkeling tot en met de metamorphose na. Ondanks de zorgvuldige en uitvoerige bewerking van laatstgenoemde bleven er nog tal van vragen over, die door Peeters, gebruik makend van de nieuwe methode der totaal preparaten, vervaardigd volgens de methode van Wijhe, voor het meerendeel tot oplossing konden worden gebracht.

Vergelijken we hetgeen van Rana in dit opzicht bekend is ge. worden met de onderzoekingen omtrent andere Anuren, dan blijkt, 
dat, hoewe! de literatuur vrij omvangrijk is, de publicatie's voor het meerendeel van vrij ouden datum zijn.

De oudere onderzoekers, Rathke (1832), Dugès (1834), Reichert (1838), Vogt (1842), waren aangewezen op de methoden van onderzoek in hun tijd gebruikelijk. Met bewondering ziet men, wat met eenvoudige kleur- en prepareermethoden tot stand kan worden gebracht, maar toch waren ze van dien aard, dat dwalingen niet uit te sluiten waren. Ook Parker (1871, '76, '82), die behalve Rana fusca de chondrocrania van talrijke Anurenspecies onderzocht, bepaalde zich tot de makroskopisch-anatomische methoden. V'aindaar dan ook, dat vele van zijn opgaven slechts onder voorbehoud kunnen aanvaard worden, icts waarop herhacldelijk (Gaupp, Peeters) gewezen is.

$\mathrm{Bij}$ de latere onderzoekers, als Goette (1875, Bombinator igncus), Born (1876, Rana esculenta, Pelobates fuscus), Stöhr (1882, Rara fusca, Hyla sp., Bufo cinereus), Schulze (1892, Pelobates fucus) Sewertzoff (1896, Pelobates friscus), Ridewood (1898, Pelodytes punctatus, Alytes obstetricans), Spemann (1898, Rana temporaria), Winslow (1898, Pipa americana), Kothe, (1910, Pelobates fuscus), Peeters (1910, Rana fusca en esculenta. Alytes obstetricans), vinit men gegevens omtrent bepaalde stadia of bepaalde gedeelten van het chondrocranium van de aangegeven vormen verspreid. Maar het meerendeel dezer onderzoekers behandelt den kraakbeenschedel slechts in het voorbijgaan in verband met hun eigenlijk onderwerp.

Een meer uitgebreid onderzoek naar de ontwikkeling van een Anurenchondrocranium heeft dus zeker recht van bestaan.

$\mathrm{Bij}$ de keuze van een bepaalde diersoort deden zich twee motieven gelden. Vooreerst was het noodig om door voldoend materiaal over de gewenschte stadia te kunnen beschikken en in de tweede plaats leek het gewenscht hiervoor een meer primitieven vorm dan Rana te kiezen.

Aan deze beide voorwaarden voldeed Alytes obstetricans. Omtrent deze soort is tot op heden betrekkelijk weinig bekend. Het onderzock van C. Vogt (1842) stond me niet ten dienste; in hoeverre het chondrocranium door hem behandeld wordt, kan ik derhalve niet uitmaken. Ridewood (1897) en Kallius (1901) beschreven de ontwikkeling van het hyobranchiaalskelet. Peeters 
(1910) had enkele larven van 25-43-50 53 m.M, tot zijn beschikking, welke hij in series en totopreparaten onderzocht. Zijn uitkomsten, waarbij de wenschelijkheid van het nagaan van jongere stadia tot juiste beoordeeling van sommige afwijkingen van Alytes ten opzichte van Rana werd uitgesproken, hebben mede de richting van het volgende onderzoek bepaald.

Mijn onderzoek strekt zich uit van den eersten voorkraakbeenigen aanleg van het chondrocranium tot aan een ontwikkelingsstadium (serie 19), dat niet ver van de metamorphose verwijderd is. De ontwikkeling tijdens en na de metamorphose tot volwassen schedel blijft voor later onderzoek en publicatie bewaard.

Tot een beter overzicht heb ik uit de geraadpleegde series een tweetal gekozen (stadium I en II), welke afzonderlijk en meer uitvoerig beschreven worden, terwijl daarna de veranderingen in tusschengelegen stadia in het kort worden samengevat.

Het eerst beschreven chondrocranium (stadium I) is dat van een larve van $7 \mathrm{~m}$.M., het eerste stadium, dat zich door voldoende kraakbeenontwikkeling er toe leende om volgens de wasplatenmethode van Born gemodelleerd te worden. Het laat zich vergelijken met de door Stöhr (1882, Taf. III fig. 18.), Gaupp (1893, Taf. XIII fig. 1) en Peeters (1910. P1. I fig. 4) algebeelde jonge stadia van Rana.

Het tweede beschreven ontwikkelingsstadium (stad. II) is hetgeen aangetroffen wordt bij een larve van $53 \mathrm{~m}$.M. lengte (staartl. 31 mM., achterp. 3 mM., voorpooten nog niet vrij). Hoewel er vergelijkingspunten zijn met het tweede door Gaupp afgebeelde en beschreven stadium van Rana fusca (larve van $29 \mathrm{mM}$.) maakt de lengtemaat het reeds waarschijnlijk, dat de ontwikkeling verder voort geschreden is. Het ligt dan ook ongeveer tusschen het tweede en derde stadium van Gaupp in.

Bij de onderscheiding van de onderdeelen van het cranium heb ik Gaupp (1893) gevolgd. Zijn nieuwe indeeling (1906), door Peeters (1910) nagevolgd, brengt de suprarostralia onder bij het splanchnocranium. Dit berust op den physiologischen samenhang van deze met de infrarostralia. Zoolang omtrent de zelfstandigheid der suprarostralia niets meer bekend is en voorloopig alleen nog de genetische eenheid met de trabeculae vaststaat, lijkt het me 
wenschelijker ze in aansluiting bij deze te behandelen. Palatoquadratum. Meckel's kraakbeen en infrarostralia, hoewel feitelijk tot het splanchnocranitum behoorend, worden om practische redenen hier tegelijk met het neurocranium behandeld.

De ontwikkeling van het hyobranchiaalskelet, dat door de onderzoekingen van Ridewood (1898), Kallius (1901) en Peeters (1910) grootendeels bekend geacht mag worden, is hier buiten beschouwing gebleven.

Ter vergelijking zullen ook nu en dan de chrondrocrania van Xenopus laevis en Pipa americana in de beschouwing betrokken worden. Door bemiddeling van Prof. Van Kampen ontving ik van Prof. M. Weber een Xenopuslarve (lengte 57,5 m.M., achterpootlengte $5 \mathrm{~m} . \mathrm{M}$.), en van Prof. W. Leche zes Pipalarven (lengte 14-15 m.M., staart verdwenen). Dr. H. W. de Graaf verschafte me enkele Pipalarven in de metamorphose (totale lengte $\pm 20 \mathrm{~m} . \mathrm{M}$., staartlengte $\pm 10 \mathrm{~m} . \mathrm{M}$.). Ondanks de vele moeite en inspanning, die de heer Reyne, entomoloog te Paramaribo, zich getroost heeft, mocht het hem niet gelukken mij jongere larvenstadia van Pipa te doen toekomen. Wel ontving ik van hem een uitstekend gefixeerde en geconserveerde rughuid met een groot aantal $( \pm 70)$ jongen, die gedeeltelijk reeds hun broedkamers verlaten hadden.

Aan alle bovengenoemde schenkers spreek ik hierbij mijn bizonderen dank uit.

Ten slotte moge er hier op gewezen worden, dat het literatuuroverzicht en meer algemeene beschouwingen na de behandeling van ieder onderdeel van het chondrocranium geplaatst zijn. 


\section{Materiaal en Techniek.}

Het materiaal van Alytes, dat mij in alc. $90 \%$ geconserveerd ten dienste stond, was, wat de jongere stadia betreft, gefixeerd in Flemming's vloeistof en pikrine-zwavelzuir; wat de oudere vanaf $71 / 2 \mathrm{~m} . \mathrm{M}$. aangaat, in Zencker's vloeistof, welk fixatiemiddel zich wederom voor Anurenlarven zeer bruikbaar bewees.

De jongere stadia tot $7 \frac{1}{2} \mathrm{~m} . \mathrm{M}$. werden gekleurd in Ehrlich's haematoxyline en eosine, hetgeen zeer goede differentiatie van het steeds zoo moeilijk te kleuren eerste kraakbeen geeft. Voor oudere stadia werden verschillende kleurmethoden toegepast.

Tot mijn verwondering bleek, dat victoriablatı, hetwelk na de Zencker-fixatie geen kleuring deed verwachten, op het objectglas het kraakbeen in coupes van niet te jonge stadia intensief blauw kleurde. De kleurstof liet zich uit het omliggende weefsel door alcohol $70 \%$ volledig uittrekken. De coupes van in boraxkarmijn in toto gekleurde larven, werden op het objectglas $5 \mathrm{~min}$. in $2 \%$ oplossing victoriablauw in alc. $64 \%$ gekleurd, in alc. $70 \%$ uitgetrokken, opgevoerd en even nagekleurd in eosine in alc. $96 \%$. De beelden zijn verrassend: kraakbeen helder blauw, kernen donkerrood, spier- en ander weefsel licht rose. Eigenaardig was het op te merken, dat jong kraalkbeen zich niet liet kleuren en bij larven in de metamorphose het kraakbeen slechts gedeeltelijk de kleurstof wilde aannemen, zoodat de kleuring alleen geschikt bleek voor larven van $14 \mathrm{~m} . \mathrm{M}$. lengte tot larven juist vóór de metamorphose.

Thioninkleuring in navolging van Fuchs (1907), die speciaal voor jong kraakbeen werd aanbevolen, gaf wel een uitstekende kernkleuring, maar het kraakbeen zelf kleurde zich uiterst weinig violet, zoodat deze methode niet de gewenschte resultaten gaf. 
Sommige in boraxkamijn in toto gekleurde series werden met Bleu de Lyon nagekleurd. Deze kleuring '), welke oorspronke lijk als plasmakleuring na het boraxkamijn bedoeld was, brachteen tot nu toe niet bekend gedrag tegenover elastine in 'talgemezn aan 't licht. Het bleek, dat elastische vezels in bloedvaten en longen zeer helder blauw gekleurd worden en men dit weefsel op andere plaatsen in den kraakbeenschedel kan terug vinden. Met name geldt dit voor de aanhechting van den proc. basalis aan den schedel in serie 22 en voor de bevestiging van het operculum in de fenestra ovalis: het fenestrale weefsel kleurt zich intensief.

Doch bovenal van belang was het te constateeren (serie 19), hoe de intercellulaire schotten van het pars reuniens weefsel der hyoieden en 't weelsel, dat de infrarostoalia verbindt, eveneens sterk blauw gekleurd werden, in tegenstelling met het omliggende (zie infrarostralia).

Dat we hier van een elastinekleuring mogen spreken, wordt door het volgende waarschijnlijk gemaakt:

le Orceine $(1 \%$ in alc. $96 \%+1 \% \mathrm{H} \mathrm{Cl})$, kleurt ditzelfde weefsel donker bruin, het kraakbeen niet. ) Deze kleuring wordt door Unno voor elastine aanbevolen (v.g.l. Encyclopaecie der Mikr. Technik, 1903, pag. 193).

2e. De elastische vezels in bloedvaten en longen worden blauw gekleurd.

De nummering der series geschedle doorloopend naar het stadium van ontwikkeling. De geraadpleeghic series zijn hieronder onder verme!ding vin nummer, lengte, fixatie, kletring en snijrichting in een tabel vereenigd. De dikte der coines badroeg steeds 0,01 m.M., uitgezonderd serie $19,20 \mathrm{en} 22$, welke 0,15 m.M. dik gesneden werden.

1) De nakleuring met Bleu de Lyon geschicdt op dezelfde wijze als met cosine; de preparaten worden korten tijd in een oplossing v. Bleu de Lyon in alc. $96 \%$ gebracht, even uitgespoeld in alc. $96 \%$ cn opgevoerd. Concentratie naar verkiezing te regelen.

2) Weigert's elastinckleuring gaf geen sprek... ie iesul'iuten, daar het kraakben door de resorcine-fuchsine sterk violet werd gekl.urd. Het pars reuniers-weefsel was donkerder gekleurd dan het omliggende kraakbeen. 
Zooals uit onderstaande tabel blijkt werden ook series vau larven in en na de metarmorphose (serie 20, 21 en 22) ter vergelijking bestudeerd.

\begin{tabular}{|c|c|c|c|c|c|c|c|c|}
\hline \multirow{2}{*}{ Serie } & \multicolumn{4}{|c|}{ Afmetingen in m.M. } & \multirow{2}{*}{ Fixatie } & \multirow{2}{*}{ Kleuring } & \multirow{2}{*}{ Snijrichting } & \multirow{2}{*}{ Opm. } \\
\hline & Tot.L. & St. L. & A.L. & V.L. & & & & \\
\hline 1 & $+1 / 2$ & & & & Fl. & EH. $-\mathrm{E}$. & Sag. & a \\
\hline 2 & $41 / 2$. & & & & , & . & Hor. & $\mathrm{b}$ \\
\hline 3 & 5 & & & & $"$ & $" \quad$, & , & c \\
\hline 4 & 5 & & & & P.Z. & . " & , & 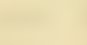 \\
\hline 5 & 6 & & & & $\ldots$ & " $\quad$ & , & \\
\hline 6 & 6 & & & & $"$, & $" \quad$ " & . & \\
\hline 7 & $61 / 2$ & & & & " " & $" \quad \quad "$ & $"$ & \\
\hline 8 & 7 & & & & . . & " & Dwars & \\
\hline 9 & 7 & & & & " " & . & " & $d$ \\
\hline 10 & $71 / 2$ & 4 & & & $\mathrm{Z}$. & BK-VB-BL & , & \\
\hline 11 & $81 / 2$ & 5 & & & $"$ & TB-E & Sag. & \\
\hline 12 & $81 / 2$ & 5 & & & , & BK-VB-BL & Hor. & \\
\hline 13 & $9 l_{1 / 2}$ & $51 / 2$ & & & , & EH-E & Dwars & \\
\hline 14 & $12 u_{2}$ & $71 / 2$ & & & " & BK-VB-E & " & e \\
\hline 15 & 16 & $81 / 2$ & & & $"$ & $" \quad " \quad$ & . & \\
\hline 16 & 22 & 12 & & & $"$ & $" \quad " \quad$ & " & \\
\hline 17 & 25 & 13 & & & $\therefore$ & BK-TB-E & $"$ & \\
\hline 18 & 29 & 16 & $11 / 2$ & & , & BK-VB-E & Hoi. & \\
\hline 19 & 53 & $311 / 2$ & 3 & & " & BK-BL & Dwars & $\mathrm{f}$ \\
\hline 20 & 62 & 37 & 18 & 7 & $"$ & $" \quad$, & " & g \\
\hline 21 & 55 & 31 & 30 & $|121 / 2|$ & , & BK-VB-E & . & $\mathrm{h}$ \\
\hline 22 & 29 & ontbr. & 43 & $|171 / 2|$ & . & BK-BL & " & i \\
\hline
\end{tabular}

\section{Afkortingen :}

A.L. Achierpootlengte; BK. Boraxkarmijn; BL. Bleu de Lyon; E. Eosine; EH. Ehrlich's Haematoxyline; F1. Flemming's vlosistof; P.Z. Pikrine-zwavelzuur; St.L. Staartengte: TB. Thionin úlaurv; Tot. L. Totale lengte; VB. Victoriablauw: V.L. Voorpootlengte; Z. Zencker's vloeistof.

Opmerkingen :
a. geen uitwendige kieuwen, oog nog niet gepigmenteerd;
b. id d. $\quad$ oog gepigmenteerd:
c. uitwendige kieuwen:
d. eerste stadium, wasmodel:
e. uitwendige kieuwen verdwenen:
f. tweede stadium:
g. linkervoorpoot nog niet doorgebroken;
h. staart in reductie:
i. spiraculum verdwenen. 
Behalve door series werd ook door het bestudeeren van totaalpreparaten getrachteen beeld van den ontwikkelingsgang te vormen.

Door Peeters (1910) werd de kleurmethode met methyleen- of victoriablauw volgens Van Wyhe nauwkeurig beschreven en terecht aan gespoord tot het vervaardigen van dergelijke instructieve mikroskeletten. Van de uitstekende resultaten, die daarmede verkregen worden, kon ik me enkele jaren geleden door toepassing der methode bij een aantal Rana fusca-larven overtuigen.

Bij de mij ter beschikking gestelde Alyteslarven bevond zich echter geen enkele, die op de door Peeters aanbevolen wijze in sublimaat-formol gefixeerd was (zie Tabel). Het meerendeel der larven was in Zencker's vloeistof gefixeerd, dat het voor het hechten der kleurstof, naar mondelinge en schriftelijke mededeeling van Dr. Peeters en Prof. Van Wyhe, schadelijke azijnzuur bevat. Mijn ervaring met de vroeger genoemde boraxkarmijn-victoriablauw-objectglas-kleuring deed me intusschen vermoeden, dat ook hier totokleuring niet uitgesloten zou zijn. Inderdaad gelukte het met victoriablauw een goede, zij het dan ook niet intensieve blauwkleuring te verkrijgen (larve $27 \mathrm{~m} . \mathrm{M}$.).

Daarmijn pogingen om metmethylcenblauw ophet objectglas tekleuren geen resulaat hadden gehad, meende ik, dat totokleuring evenmin zou gelukken. Intusschen werd mijn vermoeden niet geheel bewaarheid. Er vond wel degelijk kraakbeenkleuring plaats (larven 60 en 53 m.M.), doch op andere wijze dan normaliter geschiedt. De kleuring, die thans verkregen werd, herinnert sterk aan die door Peeters (1910) beschreven werd voor Siredon; daar kleurden zich n.l. kern en cytoplasma intensief blauw, de intercellulaire stof daarentegen niet. $\mathrm{Bij}$ een gewenschte en normale kleuring is juist het omgekeerde het geval. Bij Alytes waren behalve de kern ook de kraakbeenkapsels duidelijk yckleurd; op sommige plaatsen echter ook de intercellulaire stof.

Volgens Peeters is dit eigenaardig gectrag niet aan een bizondere eigenschap van het Siredon-kraakbeein toe te schrijven, maar vermoedelijk aan een ziekelijken toestan! der dieren. Een enkele maal kwam het ook wel voor bij een Triton-larve, en eens ook bij kleuring met victoriablauw na formol-fixatie bij een larve van 65 m.M. (Triton vulgaris), terwijl op gelijke wijze gefixeerde volwassen 
dieren het verschijnsel niet vertoonden. Zoolang er echter omtrent de chemische samenstelling van het kraakbeen der Amphibiën in de verschillende perioden van de ontwikkeling niets bekend en de verschillende werking van fixatiemiddelen en kleurstoffen niet nader bepaald is, is er voor de onderstelling van een ziekelijken toestand nog geen grond. Dat het kraakbeen in éénzelfde chondrocranium zeer verschillend in samenstelling kan zijn, leert serie 21 van een Alyteslarve in de metamorphose, gefixeerd in Zencker en met victoriablauw gekleurd. In de regio otica is de kleuring. speciaal der kraakbeenkapsels zeer intensief, daarentegen heeft een groot deel van het kraakbeen, vooral het juist gevormde en het verdwijnende zich volstrekt niet gekleurd. Aan dit laatste is het dan ook toe te schrijven, dat bovengenoemde kleuring mij bij zeer jonge larven en bij larven in de metamorphose in den steek liet. Sublimaat-formol-fixatie schijnt hiervoor bepaald noodzakelijk.

Een deel van het materiaal was echter in pikrine-zwavelzuur gefixeerd en behalve bij zeer jonge larven gelukte het in dit geval steeds met methyleenblauw ${ }^{1)}$ een diepe, bijna zwarte blauwkleuring te verkrijgen, die voor die der in sublimaat-formol gefixee:de larven in geen enkel opzicht onder behoeft te doen.

Het zijn dan ook deze larven, varieerend tusschen 9 en 32 m.M., die mede ter bestudeering gebruikt werden.

Tenslotte is hier een woord van zeer hartelijken dank op zijn plaats aan Dr. H. W. de Graaf, Conservator aan het Zoölogisch Laboratorium te Leiden, voor de welvillendheid en groote bereidwilligheid, waarmede hij het door hom reeds dertig jaren geleden verzamelde en uitmuntend gefixeerde materiaal geheel belangeloos en onbeperkt ter beschikking stelde.

1) In de bereiding der methyleenblauw-oplossing werd eenigszins, hoewel zonder bepaalde bedoeling van het door Peeters aangegeven recept afgeweken. 40 c.c.M. aangezuurde alc. methyleenbl.opl. ( $1 / 4 \%$ methyleenbl. in alc. $64 \%$ en $1 \%$ H.Cl.) werd met 40 c.c.M. alc. meth.bl.opl. (als boven zonder $\mathrm{H} . \mathrm{Cl}$.) tot droog ingedampt en opgelost in 15 c.c.M. zoutzuren alcohol (alc. $64 \%+1 / 4 \%$ H.Cl.). 


\section{De eerste ontwikkeling van het Chondro- cranium tot en met stadium I.}

\section{A. PLANUM BASALE, OCCIPITAALBOOG, CHORDA DORSALIS.}

Stadium I. (larve 7 m.M. serie 9, Pl. I, fig. 1 en 2).

Ter weerszijden van de chorda treffen we een kraakbeenstrook aan, die zich rostraal verbreedt en overgaat in het kraakbeen der trabekels, caudaal smaller wordt, zich van de chorda verwijdert en overgaat in een voor -kraakbeenig weefsel, dat dorso-lateraal ombuigt en zich tegen het oorkapsel aanlegt. Lateraal sluit de kraakbeenstrook zich aan bij het ventro-mediale oorkapselkraakbeen (zie Pl. I, ifig. I en 2, waar de grens tusschen beide door cen stippelijn is aangegeven). Daar het parachordale kraakbeen sagittaal over den geheelen afstand continu is en even hoog blijft, is een verdeeling in twee of drie gedeelten naar den vorm niet mogelijk.

De chordapunt is dorsaal omhoog gebogen; rostraal hiervan vereenigen zich beide parachordaalplaten in het ongepaard planum trabeculare.

Het kraakbeen dorsaal en ventraal van de chordapunt gaat caudaal over in een laagje voorkraakbeenig weefsel, dat de chorda ventraal slechis over een kleinen afstand bedekt, dorsaal daarentegen, in hoogte langzaam afnemend, nog ver caudaal te vervolgen is (lig. 1). Dit weefsel bestaat uit sterk afgeplatte cellen en sluit aan bij het parachordaal kraakbeen.

Caudaal wordt het parachordaal kraakbeen vrij plotseling smaller en verwijdert het zich van de chorda; hier ligt de overgang in den occipitaalboog, die nog slechts gedeeltelijk kraakbeenig is; het voorkraakbeenig weelsel buigt zich lateraal en tenslotte dorsaal 
om, zoodat het oorkapsel medio-caudaal bereikt wordt. Het gedeelte, dat het oorkapsel raakt, is over een korten afstand in kraakbeen overgegaan. Dit kraakbeenig gedeelte van den occipitaalboog is van het oorkapsel duidelijk afgegrensd. N.IX en X worden caudaal door den toekomstigen occipitaalboog omsloten en aldus wordt het foramen jugulare gevormd.

Lateraal sluit het parachordaal kraakbeen aan bij den reeds kraakbeenigen bodem van het oorkapsel. Tusschen deze beide kan men over den geheelen afstand een vergrociingsgrens aangeven, die zichtbaar is, doordat het kraakbeen zich daar niet of nauwelijks ontwikkeld heeft.

\section{Ontwikkeling.}

A) Basaalplaat.

1) Afgrenzing der basalplaat.

De kraakbeenige basaalplaat zien we voor het eerst optreden in larven van $6 \mathrm{~m} . \mathrm{M}$. (series 5 en 6). In deze stadia ziet men evenmin als in cen larve van $6 \%$ m.M. (serie 7) cen kraakbeenige verbinding met het oorkapsel; steeds blift er een strook tusschen basaalplaat en ventralen lraakbeenigen oorkapselwand, waarin we geen kraakbeen aantreffen. In een larve van 7 m.M. (serie 8) heeft het kraakbeenige planum basale reeds een aanzienlijke dikte bereikt en sluit het kraakbeen-proton van het oorkapsel hierbij aan, duidelijk afgegrensd door zijn geringe dikie (de helft van die van de basan!plaat); in dii proton vincien we een zelfstandig centrum van kraakbeenvorming, ventro-mediaal van den sacculus gelegen, van waruit de rerbinding tusschen basanlplat en oorkapselwand tot stand zal komen. Er is dus alle reden om het kraakbeen, dat vanuit dit centrum den ventro-medialen wand van het oorkapsel vormt, tot het oorkapsel te rekenen en niet tot de basaalplaat. Het verkraakbeenen van dit deel van den oorkapselwand gaat niet van de basaalplaat uit, maar sluit zich er bij aan. Een grens tusschen beide is ook in serie 9 nog duidelijk aan te geven.

Rostraal gaat de basaalplaat over in de trabeculax. Aanvankelijk is het weefsel vóór de chordapunt gelegen nog nief verkranlbeend 
(serie 2, 3, 4, 5): eerst in serie 6 wordt het kraakbeenig planum trabeculare gevormd (larve $6 \mathrm{mM}$.). Caudaal gaat de basaalplaat in de nog voorkraakbeenige weefselstrook van den occinitaalboog over.

\section{LITERATUUR.}

Wanneer men Gaunp's beschrijving van de basaalplaat voor zijn cerste stadium van Rana fusca nagaat (1893,1906), dan blijkt, dat hij het kraakbeen tusschen de commissura basicaps. ant. en post., ventraal van den $N$. VIII en het mediale deel van den sacculus, als een laterale voortzetting van de basaalplaat beschouwt. Zoo zegt hij (1893, pg. 373), dat bij een larve van $14 \mathrm{~m} . \mathrm{M}$. „schon jetzt ein Theil des häutigen Labyrınthes seine Stütze von Knorpel erhält, der sich von der Chorda aus gebildet hat, d.h. der den vorgeschobenen Theil der Basalplatte darstellt".

Peeters (1910) sluit zich bij deze opvatting van Gaupp, volgens welke dus het periotisch kraakbeen geen deel zou hebben aan de mediale begrenzing van de primaire fenestra ovalis aan. Hij ziet na de voltooing van het flanum trabeculare het eerste kraakbeen lateraal van de myotomen optreden en mediaal van het oorkapsel; dit dunne kraakbeenstukje, dit ter hoogte van het ganglion acusticum het dikste is, sluit zich craniaal aan bij het planum trabeculare. Daarna gaan de myotomen in kraakbeen over cn komt de basaalplaat door vergroziing van dit parachordaal kraakbeen met het eerste kraakbeenstrookje tot stand (dit laatste wordt door Peeters niet nader aangegeven, maar ligt voor de hand).

De opvatting van Stöhr (1882), die wel zegt, dat het oorkapsel zelfstandig verkraakbeent, maar op grond van het feit, dat hat mesotisch weefsel in het vliezig oorkapsel overgaat, het oorkapsel tot cen deel van het mesotisch kraakbeen rekent, blijft hier buiten beschouwing, daar hij over de wijze van verkraakbeening niets mededeelt.

Lijnrechi tegenover hize beide auteurs staat de meening van Götte (1875. pg. 365), die gelijktijdig met de ontwikkeling van het parachordaal kraakbeen om het gehoororgaan een kraakbeenkapsel ziet ontstaan, warvan de binnenrand met de schedelbasis versmelt 
door mediaal uit te groeien. Wel, zegt hij, kan daardoor „leicht der Eindruck hervorgerufen werden, als sei wenigstens die horizontale, die Gehörorgane tragende, Platte jener Knorpelkapsel als unmittelbare Fortsetzung der knorpeligen Schädelbasis aus dieser hervorgewachsen."

Voor Alytes kan ik me het beste bij de opvatting van Götte aansluiten. Het vroegtijdig optredende kraakbeenstrookje door Peeters beschreven, behoort m.i. tot het periotisch kraakbeen, wat uit het zelfstandig optreden lateraal van de myotomen ook blijkt.

Doordat bij Alytes het parachordaal kraakbeen zich zoo vroeg ontwikkelt en het aangrenzend deel van den oorkapselwand eerst later verkraakbeent, is de grens van de basaalplaat hier duidelijker dan bij Rana. Gaupp's eerste stadium is reeds te oud om nog een oordeel over de herkomst der deelen te kunnen uitspreken.

Het verdient dus aanbeveling de term basaalplaat te beperken tot de kraakbeenplaten, die ter weerszijten van de chorda gelegen zijn en niet uit te breiden tot het ventromediaal van de primaire fenestra ovalis gelegen kraakbeen, dat er eerst later mee versmelt.

2) Componenten der basalplaat.

Daar, zooals boven reeds gezegd werd, de parachordaalplaat in een larve van $7 \mathrm{~m} . \mathrm{M}$. noch door verschillen in dikte, noch in haar structuur een samenstelling uit meerdere gedeelten verraadt, is het van belang na te gaan of de ontwikkelingsgeschiedenis hieromtrent iets aan het licht brengt.

Reeds terstond dient medegedeeld te worden, dat we steeds, zoowel in kraakbeenige als in voorkraakbeenige stadia één continue weefselstrook ter weerszijden van de chorda aantreffen.

In de series $5,6,7,8$ vinden we een kraakbeenige parachordaalplaat, in 3 en 4 is de aanleg door de dichtopeengelegen mesenchymkernen zichtbaar. De kraakbeenontwikkeling neemt ter weerszijden van de chordapunt een aanvang, hetgeen den eersten aanleg van het planum trabeculare vertegenwoordigt. Een afzonderlijke kraakbeenkern tusschen oorkapsels en chorda gelegen, hetgeen op den aanleg van het "mesotisch" kraakbeen zou wijzen, werd niet gevonden, daar reeds in serie 5 de parachordaalplaat geheel in kraakbeen is overgegaan. 
Hocwal dus langs directen weg de samenstelling van de parachordactplaat hier niet nagegaan kon worden, is ze toch op grond van audere gegevens met vrij groote zekerheid te bepalen.

Immers hiermede is de vraag, hoeveel postotische segmenten aan de kopvorming deeinemen en waar de ligging van den occipitaalboog ten opzichte van deze segmenten te zoeken is, zeer nauw verbonden.

Wanneer we aunuemen, zooais gemeenlijk geschiedt (Gaupp, 1905, Peeters, 1910), dat er drie postotische segmenten zijn en de occipitaalboog tusschen het laatste postotische myotoom en het cerste rompmyotoom gevonden wordt, dan volgt hieruit, dat men ook een drieledige samensielling van de basaalplaat mag verwachten, n. 1.:

le het planum trabeculare, $2 e$ het "mesotisch" kraakbeen, ontstaand terplaatse van het tweede postotische myotoom en $3 e$ de occipitaalplaat, die de plaats van het derde postotische myotoom inneemt (Peeters, 1910: Rana).

Mocht echter blijken, dat er slechts twee postotische segmenten aan de kopvorming deelnemen en de occipitaalboog tusschen het tweede kopsegment en het eerste rompsegment valt, dan is een tweeledige samenstelling der basaalplaat waarschijnlijk gemaakt.

Aan de hand der series 2, 3, 4, 7, 12, 18 mogen de veranderingen, die in dit gedeclte van den kop plaats vinden, in het kort beschreven worden. In schema 1, Pl. II, zijn de resultaten overzichtelijk samengevat.

Serie 2 (Schema 1a, Pl. II).

Ter weerszijden van de chorda liggen de myotomen, begin'ıend vanaf het punt, waar de N. X uit de hersenen ontspringt (fig. 5. Pl. II). Ze vertoonen reeds een begin van spiervezelontwikkeling; de myosepta, ganglia, cutisplaten en intersegmentaalarteriën zijn duidelijk waanneembaar. Vóor het eerste craniale myotoom (R.S.1) I) zien we resten van een onvolledig ontwikkeld myotoom (K. S. II), hetgeen zichtbaar is aan de rangschikking der mesen-

') In het vervolg zal rompsegment 1, 2, etc. afgekort worden tot R.S. 1, R.S. 2 , etc. evenzoo kopsegment I en II tot K.S. I en K.S. II. 
chymkernen ter plaatse, waaraan in sommige doorsneden caudaal de myotoomvorm nog te herkennen is en aan den spiervezelaanleg in het deel, dat grenst aan R.S. 1 (fig. 5 en 6, Pl II) en door het eerste myoseptum hiervan gescheiden wordt.

Mediaal van dit eerste myoseptum ligt ter weerszijden van de chorda een bloedvat, dat dorsaal uit den radix aortae ontspringt. De arterie, die op dit stadium niet verder te vervolgen is, blijkt later te zijn de arteria occipito-vertcbralis. Wegens haar ligging ten opzichte der myotomen kau ze ter orienteering dienen; daarom wordt ze hier genoemd.

Bij alle myotomen is de aanleg van het bijbehoorend ganglion duidelijk, behalve bij het eerste (R.S. 1), dat zwakker ontwikkeld is dan de overige.

Het kopmesenchym vóór de myotomen en de chorda, die zich slechts tot bijna halverwege de gehoorblaasjes uitstrekt en het infundibulum niet bereikt, vertoont nog geenerlei differentiatie, die op toekomstige kraakbeenvorming wijst.

Serie 3 (Schema $1 b$, Pl. II).

Van de myotomen, die zich tot den oorsprong van den N.X uitstrekken, zijn de eerste twee dorsaal vergroeid.

Voor het eerst valt in het verlengde der myotomenreeks naar voren een eigenaardige rangschikking der kernen van het kopmesenchym waar te nemen, als eerste aanduiding van het ontstaan der parachordalia.

Deze beide mesenchymstrooken buigen ter hoogte van de chordapunt buitenwaarts en gaan zonder scherpe grens in het kopmesenchym over. Vóór de chordapunt zijn beide strooken door een dwarsbrug van donker gekleurd mesenchym vereenigd; de donkere kleur van dit weefsel wordt, evenals dat van de mesenchymstrooken in 't verlengde der myotoomreeksen, veroorzaakt door de dichte groepecring der kernen en het groot aantal dooierkorrels.

Van den spiervezelaanleg in K.S. II is slechts zeer weinig overgebleven. De myotoomvorm is caudaal aan de rangschikking der kernen nog goed waarneembaar (fig. 7 en fig. 8, Pl. II).

De ganglionaanleg bij het myotoom R.S. I is nauwelijks waarneembaar, die der overige zeer duidelijk. 
De arteria occipito-vertebralis is een weinig caudaal van he myoseptum tusschen K.S. II en R.S I. gelegen (fig. 8).

Serie 4 (Schema 1 c, Pl. II).

In het verlengde der rompmyotomen ligt een strook parachordaal weefsel, dat zich door zijn donkere kleur en structuur duidelijk van het overige mesenchym onderscheidt en als kraakbeen-proton beschouwd mag worden (fig. 10, Pl. II).

De myotomen R.S. 1 en 2 liggen evenals in voorgaande series een eindweegs achter het gehoorblaasje. Het dorsale deel van K.S. II is nog herkenbaar aan de rangschikking der mesenchym kernen tusschen de gehoorblaasjes en R.S. 1. Van de dorsale vergroeiing van R.S. 1 en 2 is in deze en volgende series niets met zekerheid waar te nemen.

Het eerste rompmyotoom (R.S. 1), waarvan het ganglion niet meer met zekerheid is aan te toonen, is ventromediaal in reductie (fig. 10); ventraal leggen de myotomen zich dichter tegen de chorda; de arteria occipito-vertebralis, nu halverwege R.S. 1 gelegen, neemt door het mesenchymatische spiervezelvrije deel van dit myotoom haar weg (fig. 10). De craniale grens van dit myotoom is ventraal nog duidelijk te zien door het ervoor liggende donkere parachordaalweefsel (fig. 10).

Deze weefselstrook versmalt zich naar de chorda toe, verbreedt zich weer (zandloopervorm) en gaat over in de basis van de U-vormige weefselverdichting, die de hersenen ventrolateraal omgeeft. Ook vóór de chorda ligt dit prochondrale weefsel.

Het parachordaal kraakbeen-proton zet zich caudaal voort in het voorkraakbeenige weefsel van den occipitaalboog, die zich zwak dorsolateraal ombuigt en zich spoedig in het mesenchym achter het gehoorblaasje verliest.

Het occipitaalboog-proton ligt tegen het myoseptum K.S. IIR.S. 1 aan. (fig. 9).

\section{Serie 7 (Schema 1d, Pl. II).}

Het parachordale voorkraakbeenige weefsel is nu over de geheele lengte in kraakbeen overgegaan en zet zich caudaal voort in den nog voorkrakbeenigen occipitaalboog, die spoedig inge- 
sloten wordt tusschen ganglion N.X en R.S. 2, daar R.S. 1 hier ter plaatse bijna geheel gereduceerd is. De occipitaalboog buigt zich caudaal van den N.X naar het gehoorblaasje toe en legt zich tegen het oorkapselproton aan. Ook vóó de chordapunt heeft zich kraakbeen ontwikkeld (fig. 12, Pl. II). Het middengedeelte van R.S. 1 is sterker gereduceerd dan in serie 4. Alleen ventro-lateraal (fig. 12) vinden we nog spiervezelontwikkeling en ook dorsaal als aanhechting aan den toekomstigen oorkapselwand (f,ig. 11).

De art. occipito-vertebralis ligt ongeveer tegenover het midden van het ventrale deel van R.S. 1 (fig. 12).

De ganglia zijn alle even sterk ontwikkeld en vangen aan bij R.S. 2 .

Serie 12 (Schema 1e, Pl. II).

R.S. 2 hecht zich direct aan het kraakbeenige oorkapsel, daar de dorsale spiervezels van R. S. 1 te dezer plaatse bijna geheel gereduceerd zijn. Alleen ter hoogte van de aanhechting van den occ.-boog aan het oorkapsel zijn nog enkele spiervezelresten van R.S. 1 te vinden (fig. 13, Pl. II) en ook ventraal vindt men nog een enkel overblijfsel van een spiervezel terug. R.S. 1 is derhalve bijna volkomen verdwenen en zijn plaats gedeeltelijk ingenomen door de parachordaalplaat, die zich in caudale richting heeft uitgebreid. De occ.-boog is links op een klein middengedeelte na geheel kraakbeenig, rechts nog niet.

Het ganglion bij R.S. 2 is zwak ontwikkeld; dat bij R.S. 3 beter, hoewel minder dan de volgende.

De art. occipito-vertebralis ligt in de mesenchymatische weefselstrook tusschen R.S. 2 en de parachordaalplaat.

\section{Serie 18 (Schema $1 f$, Pl. II).}

Het parachordale kraakbeen is caudaal scherp begrensd; doordat het achterwaarts uitgegroeid is, hebben deocc.-bogen, die nu geheel kraakbeenig zijn, een verticalen stand ingenomen, in tegenstelling met den toestand in vorige stadiën waar zij een min of meer scherpen hoek met het horizontaal vlak maken (zie fig. 1 en 2, Pl. I).

De wervels zijn in dit stadium kraakbeenig en door vergelijking met voorafgaande stadiën is nu te bepalen, waar de eerste en tweede 
wervel ten aanzien der myotomen komen te liggen. Uit fig. 14 , Pl. III en in verband met voorafgaande series is het duidelijk, dat de tweede wervelboog ligt in het myoseptum van R.S. 2 en R.S. 3.

Hieruit volgt (zie vorige schema's), dat de eerste wervel gedacht moet worden tusschen R.S. 1. en R.S. 2. en de occ.boog tusschen K.S. II en R.S. 1. Inderdaad vindt men ook in serie $t$ het kraakbeenproton van den occipitaalboog tegen het myoseptum van K.S. II en R.S. 1 aanliggend.

Door het ontbreken van series, waarin het eerste optreden van den eersten wervel nagegaan kon worden, kon omtrent diens ligging geen directe waarneming geschieden, maar in verband met Schema $1 f$ blijft slechts de genocmde mogelijkheid over.

Het myotoom R.S. 1 is nu geheel gereduceerd.

Op de grens van parachordaalplaat en ecrste wervellichaam treffen we de art. occipito-vertebralis aan, dorsaal opstijgend tusschen occipitaalboog en eersten wervelloog (fig. 14) en zich nauw aansluitend aan den medio-caudalen oorkapselwand. De oorsprong der arterie is caudaal verschoven en ligt ter hoogte van R.S. 2.

Alle spinale zenuwen hebben cen dorsalen en ventralen wortel, uitgezonderd de eerste, behoorend bij R.S. 2, welke alleen een ventralen wortel ontwikkelt (fig. 14).

\section{Samenvatting.}

Overziet men, hetgeen uit de besproken series volgt, dan komt men tot deze opvatting.

In den loop der ontwikkeling ziet men twee segmenten ver dwijnen. Hiervan vertoont het meest craniale (K.S. II) alleen caudaal nog spiervezelaanleg; het tweede (R.S. 1) ontwikkelt zich tot een volledig myotoom met bijbehoorend zwak ganglion. Dit myotoom wordt evenals het ganglion geheel gereduceerd ${ }^{1}$ ).

De occipitaalboog ligt tusschen K.S. II en R.S. 1; de eerste wervel tusschen R.S. 1. en R.S. 2 ; binnen het segment R.S. 1 valt de craniovertebrale grens. Het myotoom R.S. 2 hecht zich direct aan het

1) De mogelijkheid moet blijkens serie 3 gesteld worden, dat enkele dorsale splervezels van R.S. 1 zich bij die van R.S. 2 voegen en deze zich gezamenlijk aan het oorkapsel hechten. 
oorkapsel; het bijbehoorend ganglion wordit gereduceerd en er ontwikkelt zich alleen een ventrale spinale zenuwwortel. De overige myotomen hebben overeenkomstige dorsale en ventrale zenuwwortels met goed ontwikkelde ganglia.

De ligging van K.S. II in de onmiddelijke nabijheid van het ganglion N.X op het jongste onderzochte stadium (serie 2) wijst er reeds op, dat dit segment bij genoemde zenuw behooren moet ${ }^{1}$ ).

Uit Schema $1 f$ volgt eveneens, dat dit met recht verondersteld mag worden. Immers, caudaal beginnend vindt men voor R.S. 3 een dorsalen en ventralen wortel, voor R.S. 2 een ventralen wortel, de eerste vrije spinale zenuw (hypoglossus), voor R.S. 1 een verdwijnenden ganglionaanleg, in ligging overeenkomend met de occipitaalzenuw der Urodelen. K.S. II is derhalve het vagussegment. Tevens volgt hier uit, dat er, hoewel niet waargenomen, vóór dit segment nog een ander, behoorend bij N. IX, gelegen moet hebben $\left.{ }^{1}\right)$.

We mogen hieruit dus besluiten, dat de occ.boog valt achter het tweede post-otische kopsegment en dus niet gelijkwaardig is met den occ.boog der Urodelen, welke achter het derde kopsegment ligt (Miss Platt, 1897: Necturus; Goodrich, 1911, Amblystoma).

De kop der Anuren bevat dus één segment minder dan die der Urodelen. De basaalplaat der Anuren is dan ook niet gelijkwaardig met de basaalplaat der Urodelen; is deze laatste ongetwijfeld wit drie deelen same.rgesteld (het planum trabeculare, het "mesotisch" kraakbeen en de occ.plaat), die der Anuren omvat slechts twee componenten (trabekelplaat en occipitaalplaat).

\section{LITERATUULR.}

Aangaande het aantal postotische segmenten, dat bij de Anuren aan de kopvorming deelneemt, vindt men in de litteratuur slechts weinige opgaven.

Bij Götte treffen we omtrent Bombinator enkele gegevens aan, die eenige nadere toelichting behoeven. Volgens zijn op-

1) Het materiaal van jongere stadia bleek niet voldoende geconserveerd voor een nader onderzoek, waaruit dit daadwerkelijk zou blijken.

2) Zooals later blijken zal, is dit voor andere vormen, zooals Bombinator en Pelobates, ook inderdaad bij jonge stadia gevonden. 
vatting behooren tot het kopgebied vier segmenten, waarvan het eerste tot den zgn. "Vorderkopf", de laatste drie tot den "Hinterkopf" gerekend moeten worden. Het gehoorblaasje schuift zich tusschen het tweede en derde "äussere Segment" van den kop d.w.z. tusschen den aanleg van ganglion VII en IX. Hieruit volgt dus, dat slechts twee postotische segmenten, die van IX en $X$, aan de kopvorming deelnemen. Van deze twee vormt alleen het laatste nog caudaal spiervezels (Taf. VII, fig. 122), wat dus overeenkomt met hetgeen bij Alytes gevonden werd (zie schema 1).

Daarentegen zegt Götte in de beschrijving op pg. 663, sprekende over de drie laatste ,innere Segmente” van den kop: „In ihrem Innern entsteht jederseits neben der Wirbelsaite ein Muskelstrang, an den man die Abteilung für das dritte und vierte Segment längere Zeit deutlich, diejenige für das zweite Segment dagegen nur unsicher oder gar nicht erkennt" (Taf. VI, fig. 303, 304, 314-16). Hieruit zou dus volgen, dat segment IX ook spiervezels kon vormen. De verwijzing naar bovengenoemde figuren, waarin helaas de segmenten niet met letters aangegeven staan, doet vermoeden, dat Götte zich hier vergist en abusievelijk het eerste rompsegment tot den kop rekent. Nooit, ook niet bij Úrodelen, zooals later blijken zal, werden in segment IX spiervezels aangetroffen en toch zeker niet op dit vergevorderde stadium. Men zou het eventueel kunnen verwachten in het stadium van fig. 121, maar hier is uit de nummering der segmenten het tegendeel op te maken. ${ }^{1}$ )

Het mocht mij niet gelukken, bij Götte een opgave te vinden betreffende de ligging van den eersten en tweeden wervel ten aanzien der segmenten. Wel blijkt uit fig. 326. Taf. XVIII, dat tusschen den eersten en tweeden wervel een ventrale spinale zenuw te voorschijn treedt, evenals bij Alytes. Deze ventrale wortel, door Götte hypoglossus genoemd, behoort tot het tweede rompsegment; in het eerste rompsegment komt volgens hem geen zenuw tot ontwikkeling. Daar bij Alytes deze aanleg slechts voorbijgaand is, is het mogelijk, dat ze bij Bombinator niet meer

1) Tot bevestiging van mijn meening zag ik later, dat ook Sewertzoff (1895) deze tegenstrijdigheid heeft opgemerkt cn op dergelijke wijze tracht te verklaren. Zie ook noot 2 blz. 29. 
tot uiting komt of door Götte over het hoold weri gizien. In ieder geval laat deze opgave zich in overeenstemming brengen met wat bij Alytes werd gevonden en mogen we wel concludeeren, dat ook bij Bombinator slechts twee postotische kopsegmenten gevonden worden, waarvan alleen het laatste spiervezels ontwikkelt, en dat het eenige verschil waarschijnlijk hierin bestaat, dat het segment R.S. 1 geen spinaalganglion ontwikkelt ${ }^{1}$ ).

De uitkomsten, waartoe Chiarugi (1891) geraakt bij zijn onderzoek van Bufo vulgaris, vertoonen merkwaardige overeenkomst met hetgeen Alytes te zien gaf. Chiarugi ging nauwkeurig den zenuw- en ganglionaanleg, speciaal van N.X, na ten opzichte van kop en rompmyotomen en concludeert, dat er bij Bufo slechts één kopsegment voorkomt, dat spiervezels vormt (over eenkomend met K.S. II van Alytes ${ }^{2}$ ).

Chiarugi vond, dat oorspronkelijk N.X, met dit kopmyotoom correspondeert, dat het volgend rompmyotoom een weer verdwijnend ganglion ontwikkelt, dat het laatste kopmyotoon en

1) Tevergeefs zal men in Götte's figuren zoeken naar de ligging van de art. occ.-vertebralis. Het schijnt, dat op jonge stadia bij Bombinator eerst een dorsaal bloedvat uit den aortawortel ontspringt, lateraal van de myotomen, in ligging overeenkomende met de intersegmentaalarterien. Later wordt dit bloedvat vervangen door de art. occ.-vertebralis terzelfder plaatse, maar mediaal van de myotomen ontspringend (zie fig. 371 en 377, Taf. XXI). Bij Alytes komt de primitieve art. vertebralis in de jongste stadia ook voor, maar tegelijk met de art. occ.-vertebralis.

2) Chiarugi (1891, pg. 229, 230) schrijft over hetgeen Götte bij Bombinator vond, het volgende: "Chez ce dernier (Bombinator) il s' enformerait trois (plaques musculaires), une plus antérieure avec des éléments musculaires peu évidents et €n arrière deux autres bien constituées; chez le crapaud une seule plaque musculaire est évidente. La différence de nombre observée ne dépend pas de la formation d'une plaque musculaire en moins, mais de la détermination de la limite, qui divise la série continue des plaques musculaires en plaques, qui correspondent à la tête et en plaques, qui correspondent au tronc. La première des plaques musculaires céphaliques bien constituées du Bombinator correspondrait à la plaque musculaire céphalique bien constituće du crapaud, mais la deuxième céphalique du Bombinator ne serait de fait, que la première du tronc, aussi bien chez Eombinator que chez le crapaud." Dit wijst eveneens op Göttes verkeerde opvattiag van het aantal postot. segm., dat aan de vorming van den kop deelneemt en toont nogmaals aan, dat zijn eerste opgave ( 2 postot. segm.) de juiste zijn moet. 
het eerste rompmyotoom in den loop der ontwikkeling atrophieeren en de tweede wervel tusschen het eerste en tweede blijvende rompmyotoom ligt.

Het bovenstaande kan men geheel op Alytes toepassen, slechts vindt men een geringe afwijking in de ligging der myotomen, die bij Bufo tot voorbij de caudale grens van het gehoorblaasje schijnen te reiken $\left.{ }^{1}\right)$. En ook schijnt het laatste kopmyotoom meer spiervezel-ontwikkeling (.,plaque musculaire bien constituée”) te ver toonen dan bij Alytes.

Wanneer dus volgens Chiarugi het laatste kopsegment correspondeert met N.X, mogen we aan deze conclusie de uitbreiding geven, dat er bij Bufo slechts twee postotische kopsegmenten zijn, n.l. die van N.IX en X.

Sewertzoff (1895) onderzocht zeer jonge embryo's van Pelobates fuscus, waarbij de ligging der kopsomieten ten aanzien der ganglia VII, IX en $\mathrm{X}$ nog duidelijk te zien was. Zijn bevindingen stemmen met de eerste opvatting van Götte overeen, n.l. de twee achterste inwendige segmenten (Kopfhöhlen) komen overeen met gl. IX en X. De ligging van het segment overeenkomend met gl. VII ten opzichte van het gehoorblaasje was moeilijk vast te stellen, daar het eerste verdwijnt als het laatste zichtbaar wordt; waarschijnlijk ligt het tegenover het gehoorblaasje. Het derde, door Sewertzoff waargenomen kopsomiet, dat van N.X (dus het tweede postotische) gaat volgens hem over in een myotoom, dat vergelijkbaar is met het kopmyotoom van Bufo. De somieten van VII en IX verdwijnen zonder spiervezels te geven. Het kopmyotoom N.X (= K.S. II van Alytes) verdwijnt weer in den loop der ontwikkeling, evenzoo rompmyotoom I (R.S. 1 Al.) Het verdwijnende kopmyotoom ligt vóór den occ.boog. Volgens Sewertzoff behooren dus tot den kop drie segmenten (Götte vond er bij Bombinator vier, n.l. ook nog dat van $V$ ) en van deze drie zijn de laatste twee volgens hem, mede in verband net Bombinator, met groote waarschijnlijkheid tot de regio metotica te rekenen (zie noot Sewertzoff, 1895, pg. 268) 2) "3).

1) Volgens Chiarugi zou dit karakteristiek zijn voor Amphibia.

2) Dat Sewertzoff geen absolute zekerheid weet le geven, vind zijn oorzaak hierin, dat hij, zoo als boven gezegd werd, niet met zckerheid de ligging van 
Tusschen de uitkomsten van Chiarugi, Sewerizoff en ook Götte (na correctie) bestaat groote overeenkomst en het moet daarom opvallen, wanneer men bij Peeters (1910) voor Rana fusca cn esculenta een andere opgave aantreft.

Peeters vindt bij Rana fusca-larven van $8 \mathrm{~m}$.M. en Rana esculenta-larven van $6 \mathrm{~m} . \mathrm{M}$. een tweetal myotomen, die zich tusschen de oorkapsels langs de chorda tot de trabekelplaat uitstrekken. De caudale grens van het tweede myotoom komt overeen met de caudale grens van het oorkapsel. Beide myotomen hebben een kortstondig bestaan. Het eerste verdwijnt bij een larve van $91 \%$ m.M. (Rana fusca), het tweede is bij een larve van 11 m.M. zoo goed als verdwenen. De plaats van beide myotomen wordt door het planum basale ingenomen. Het tweede myotoom schijnt zelfs onmiddelijk in kraakbeen omgezet te worden. Een dergelijke ontwikkelingsgeschiedenis brengt volgens Peeters een drieledige samenstelling der basaalplaat mede: het planum trabeculare, het mesotisch krakbeen ter plaatse van myotoom 1 en de occ. plaat ter plaatse van of ontwikkeld uit myotoom 2 .

Het komt me voor, dat Peeters' opgaven niet geheel met de werkelijkheid overeenstemmen.

Ik heb den toestand in enkele horizontaal gesneden series van Rana fusca kunnen nagaan. Bij een larve van $6^{1}{ }_{2}^{\prime} \mathrm{m} . \mathrm{M}$. trof ik tcr weerszijden van de chorda de myotomen aan. Het eerste myotoom lag ter hoogte van gl. X, ver caudaal van het gehoorblaasje en op zeer grooten afstand van de chordapunt, die zich tot het infundibulum uitstrekte. Vóór deze myotomen liggen de mesenchymkernen zonder bepaalde rangschikking verspreid. Bij een larve van $71 / 2 \mathrm{~m} . \mathrm{M}$. ligt het eerste myotoom ter hoogte van g!. X, maar nu reikt zijn craniale rand tot even voorbij den caudalen rand van het gehoorblaasje. De kernen van het mesen-

somiet VII ten aanzien van het gehoorblaasje bepalen kon. De vergelijking met de $a\lfloor b$. van Götte voor Bombinator doet hem besluiten tot twee postot. kopsomieten.

3: Te:ı onrechte noemt Delsman (1917) Sewertzoff onder degenen, die drie somieten tusschen gehoorkapsel en occ.boog vinden. De onjuistheid hiervan springt in het oog, wanrieer men bedenkt, dat Sewertsoff zijn uitkomsten bij Siredon, waar hij, hoewel ten onrechte, twee postot. somieten vond, volkomen in overeenstemming acht met hetgeen Pelobates te zien gaf. 
chym vóór de myotomen zịn nu gerangschikt en sluiten aan bij het proton der trabekelplaat, dat zich duidelijk afteekent.

In een larve van $9 \mathrm{~m} . \mathrm{M}$. vindt men het eerste myotoom liggend tusschen de oorkapsels; zijn caudale rand komt overeen met den caudalen rand van het oorkapsel. Gl. X ligt ter hoogte van het myoseptum van myot. 1 en myot. 2. Het planum trabeculare is kraakbeenig. Tusschen myotoom 1 en de trabekelplaat bevindt zich een weefselstrook, waarin de mesenchymkernen dicht opeen gelegen zijn. In het planum trabeculare en dit kraakbeen proton ziet men den toekomstigen vorm van het planum basale. De aanwezigheid der ganglia was voor alle myotomen niet met zekerheid na te gaan; het eerste myotoom bezit in dit stadium naar alle waarschijnlijkheid geen bijbehoorend ganglion.

Wanneer we dit vergelijken met hetgeen Alytes te zien gaf, dan kunnen we een zekere overeenstemming niet ontkennen.

Het eerste myotoom bij Rana komt overeen met R.S. 1 van Alytes; het daarvoor liggende mesenchym doet door zijn rangschikking de aanwezigheid vermoeden van K.S. II, waarvan de spiervezels in een larve van $6_{12}^{1} \mathrm{~m}$.M. reeds verdwenen moeten zijn. De veranderde ligging van het eerste myotoom ten aanzien van het gehoorblaasje houdt verband met het verschijnsel, dat ik evenzoo bij Alytes vond en ook door Sewertzoff (1895) werd opgemerkt, n.l. het zgn. "Einriicken der Myotome in die occipitale Region". Dit myotoom R.S. 1 is ook bestemd om evenals bij Alytes te atrophieeren.

Hoe dus Peeters bij R. fusca-larven van $8 \mathrm{~m} . \mathrm{M}$. van een myotomenreeks kan spreken, die zich tot de trabekelplaat uitstrekt, is mij niet duidelijk. Reeds op een jonger stalium $(6 \mathrm{~m} . \mathrm{M}$.), als er nog van een trabekelplaat gecni sprake is, is er een groote ruimte zelfs tusschen oorkapse! en myotomen, die door het binnendringen der myotomen in cie occ.streek wel verkleint, maar nooit verdwijnt (larve $91 / 2 \mathrm{~m} . \mathrm{M}$.).

Evenzeer is me onbegrijpelijk, hoe het bij Alytes gevonden myotoom R.S. 1 (waarschijnlijk het tweede van Peeters) in kraakbeen zou overgaan. Hoewel de series me ontbraken om dit na te gaan, lijkt het me waarschijnlijk, dat dit myotoom, evenals bij Alytes en Bufo, atrophicert en zijn plaats gedeeltelijk door de 
caudaal uitgroeiende basaalplaat of door een zich meer zelfstandig ontwikkelende occipitaalplaat wordt ingenomen.

Waar de occ.boog ten aanzien der myotomen ligt, geeft Peeters niet aan; een nader onderzoek bij Rana aangaande deze punten is dus wel aan te bevelen.

Op grond van hetgeen bij Bombinator, Bufo, Pelobates en Alytes gevonden werd meen ik de opvatting te kunnen handhaven, dat bij Anuren slecht twee postotische somieten aan de kopvorming deelnemen.

Wenden we ons nu tot de Urodelen. Hier treffen we in tegenst lling met de Anuren drie postotische somieten tusschen oorkapsel en occ.boog aan. Wanneer we het onderzoek van Sewertzoff (1895) aangaande Siredon stilzwijgend voorbijgaan, daar het latere onderzoek van Goodrich (1911) m.i. meer vertrouwen verdient, kunnen wezeggen, dat dit thans algemeen aangenomen wordt (Delsman 1917).

Miss Platt (1897) onderzocht Necturus, Goodrich (1911) Ambly stoma en beiden vinden drie postotische somieten, n.l. die behoorend bij de N.IX,X en $\mathrm{X}_{1}$ of occ. zenuw.

Bij Nectures verdwijnt het eerste postot. somiet spoedig en geeft het tweede het aanzijn aan spiervezels, waarvan de ventrale spoedig atrophieeren; de dorsale blijven en treden in verbinding met de spiervezels van het volgende myotooin. In het septum tusschen het tweede en derde postotische myotoom ligt de praeoccipitaalboog, terwijl tusschen het derde en viexdepostotische myotoom de occ.boog gelegen is ${ }^{1}$ ). Met het tweede postot. segment komt het ganglion N.X overeen, met het derde de N.X ; met segment 4 en 5 twee ventrale wortels, die den hypoglossus vormen.

Voor Amblystoma komt Goodrich (1911) tot een overeenkomstig resultaat, slechts in details ervan afwijkend; zoo vindt hij in bepaalde ontwikkelingsstadia een ventralen wortel in het derde postotische Segment en in het vijfde ook nog een dorsalen wortel; het dorsale deel van het tweede postotische myotoom blijft bestaan, evenzoo het dorsale deel van het derde. Evenals bij Necturus ontstaat de praeoccipitaalboog tusschen het tweede en derde postotische segment, de occ.boog tusschen het derde en vierde; tusschen

1) Peeters (1910) ontkent het voorkomen van een kraakbeenigen pracocc.boog bij Necturus, daar hij dien in zijn preparaten niet waarnam. 
occ.boog en eersten wervel treedt een ventrale zenuwwortel uit, die met een volgenden ventralen wortel, tusschen den eersten en tweeden wervel ontspringend, den $\mathrm{N}$. hypoglossus vormt.

Peeters (1910) nam bij Triton ook twee postotische myotomen waar (van het tweede en derde postotische somiet afkomstig); het eerste myotoom verdwijnt weer; even vóór het tweede myotoom treedt een zelfstandige kraakbeenkern op, mediaal van het oorkapsel, die de chorda spoedig bereikt. Vóór het septum tusschen het tweede en derde postotische myotoom ${ }^{1}$ ) ontstaat de occ.boog, die langs de chorda naar beneden uitgroeit en zich vergroot tot occipitaalplaat. We zien hier dus duidelijk de basaalplaat uit drie onafhankelijke stukken ontstaan: de trabekelplaat, de kraakbeenkern (de cartilago mediotica) en de occ.plaat.

Brengt men nu den toestand, zooals die bij Urodelen gevonden wordt, in een schema (zie schema 2, PI. II) ') en vergelijkt men het resultaat met hetgeen Alytes, als voorbeeld van een Anuur, te zien gaf, dan blijkt het volgende.

Segment 1 (N.IX) verdwijnt bij beiden op een zeer vroeg stadium; segment 2 (N.X) vormt bij Urodelen dorsaal en ventraal spiervezels, waarvan de dorsale blijven bestaan; bij Anuren is de spiervezelontwikkeling hier voorbijgaand; segment 3 (N.X.) (K.S. III. Urodelen = R.S., 1 Anuren) vormt bij Urodelen spiervezels, die geheel (Necturus) of alleen dorsaal (Amblystoma) blijven bestaan; bij Anuren verdwijnt ook dit myotoom in den loop der ontwikkeling; de overige segmenten komen met elkander overeen.

Segment 1 behoort bij N.IX, segment 2 bij N.X. segment 3 bij N.X. $X_{1}$, die zich bij Urodelen bij den N.X voegt (Necturus) of in de ontwikkeling verdwijnt (Amblystoma) en bij Anuren atrophieert ; bij segm. 4 behoort bij beide groepen een ventrale hypoglossuswortel; het vijfde segment vertoont bij Necturus alleen een ventralen wortel, bij Amblystoma een dorsalen en ventralen wortel, die met den voorafgaanden ventralen wortel den hypoglossus vormen. Bij Alytes vinden we hier een dorsalen en ventralen wortel ; een deelnemen hiervan aan den hypoglossus kon voor Alytes

1) Dit is het derde en vierde postot. somiet.

2. Dit schema geelt den eindtoestand voor Urodelen en Anuren weer: voor de veranderingen in den loop der ontwikkeling zie de beschrijving. 
niet nagegaan worden; bij Bombinator geschiedt dit zeker niet; bij Rana neemt een tak van de eerste spiraalzenuw met de tweede en derde aan de vorming van den plexus brachialis deel.

Tusschen segment 2 en 3 ontstaat bij Urodelen de praeocc.boog, bij Anuren de occ.boog; tusschen segment 3 en 4 bij Urodelen de occ.boog, bij Anuren de eerste wervel.

Het is dus zeer wa arschijnlijk, dat de praeocc. boogder Urodelen homoloog is met den occ.boog der Anuren; de atlas der Urodelen is niet homoloogmet dien der Anuren. De basalplat der Urodelen bestaat uit drie componenten, die der Anuren doet slechts twee componenten verwachten.

Tot nu toe bleven de Gymnophionen buiten bespreking. Dank zij de onderzoekingen van Marcus (1910b) over Hypogeophis is hieromtrent een en ander bekend geworden, hoewel zijn opgaven nog alleen staan en op sommige punten bevestiging behoeven. Om deze reden hebik de Gymnophionen in schema 2 nietopgenomen.

Marcus vindt vier postotische en twee proötische somieten, die tot den kop behooren (zie Marcus, reconstructies 1 tot 8 Taf. 25). Van deze postotische somieten vertoont het voorlaatste een voorbijgaand myotoomkarakter, maar het lost zich weer in mesenchym op; het laatste daarentegen blijft als myotoom bewaard. Vóór de eerste vrije spinaalzenuw ligt een ganglion, dat zich nauw bij den vagus aansluit; er wordt in dit segment een ventrale wortel gevonden, die in Fürbringer's nomenclatuur met $z$ is aan te duiden; vóór deze occ.zenuw $z$, vinden we nog een zenuw y en waarschijnlijk daarvoor nog twee (iv en $\mathrm{x}$ ). De occ.boog valt tusschen het myotoom behoorend bij z en dat behoorend bij N. sp. 1

Zonder nu op het verband tusschen neuromerie en mesomerie in te gaan, hetgeen de onzekerheid omtrent de zenuwen $w$ en $x$ moeilijk maakt, is het wel eigenaardig op te merken, dat we bij Gymnophionen één postotisch segment in den kop meer aantreffen dan bij Urodelen. Dit makkt het feif, dat we bij Ānuren een segment minder dan bij Urodelen aantreffen, meer aannemelijk en we kunnen dus niet zooals Gaupp (1906, pg. 721) a priori zeggen : „dass die Ausdehnung des Anuren-craniums in kaudaler Richtung die gleiche ist, wie die des Urodelencraniums ist fraglos". 
Gaan we nu na, wat ind e $\mathrm{rda}$ a d omtrent de samenstelling van de basaalplaat bij Anuren bekend is en in hoeverre dit het aannemen van twee componenten rechtvaardigt.

De term "mesotisch kraakbeen" is het eerst door Stöhr (1882) voor Anuren gebruikt. Volgens hem ziet men bij Rana temporaria achter den gepaarden aanleg van het planum trabeculare een weefselstrook, die direct zonder voorkraakbeenig stadium te door loopen in kraakbeen overgaat. Dit kraakbeen onderscheidt zich den eersten tijd van dat van het planum trabeculare, daar zijn opbouwende elementen geringer van afmeting zijn en er meer intercellulaire substantie aanwezig is. Beide kraakbeenvormingen raken elkander ter weerszijden van de chorda; het "mesotisch" kraakbeen legt zich zijdelings tegen den caudalen smallen kraakbeenigen uitlooper van de trabekelplaat. Op deze plaats zijn beide strooken zeer smal (zandloopervorm). Nooit vond Stöhr beide kraakbeenplaten afzonderlijk ; toch meent hij een zeifstandigen oorsprong voor het mesotisch kraakbeen te mogen aannemen in verband ook met het feit, dat de sterkste kraakbeenvorming te vinden is op een punt, achter de overgangsplaats van beide gelegen.

$\mathrm{Nu}$ legt zich, volgens Stöhr, achter het mesotisch kraakbeen de occ.boog zelfstandig aan, die, langzaam in kraakbeen overgaand, in verbinding treedt met het mesotisch kraakbeen.

We kunnen dus drie deelen aan de schedelbasis onderscheiden, waarvan de eerste twee op geen stadium van elkaar te scheiden zijn, n.l. a. het planum trabeculare, $b$. het mesotisch kraakbeen en c. den daarachter gelegen aanleg van den occ.boog. De laatste ontstaat als a en $b$ reeds geheel kraakbeenig zijn. Terstond mag er hier opgewezen worden, dat Stöhr bij Anuren niet spreekt van den zelfstandigen aanleg van de basis van den occ.boog, zooals bij Urodelen (1880). Hier ontstaat volgens hem eerst het planum trabeculare, dan de occ.boog, waarvan de "Basaltheile" zich naar voren verlengen tot ze elkander bereiken, terwijl het mesotisch kraakbeen (toen nog perifeer kraakbeen genoemd) ter zijde ontstaat en de chorda niet raakt.

De vergelijking van beide toestanden is niet zoo eenvoudig als Stöhr (1882) doet voorkomen, waar hij meent, dat het slechts een quaestie zou zijn van het vroeger of later optreden der com- 
ponenten (bij Anuren a.b.c., bij Urodelen a.c.b., vandaar dat b. hier geisoleerd optreedt).

Reeds Gaupp (1893, pg. 356) en later ook Peeters (1910, pg. 116 seq.) hebben daarop gewezen; moeilijkheid levert volgens hen de regio occipitalis; inderdaad heeft Stöhr, zooals gezegd, slechts van den occ.boog gesproken en niet van de occ.plaat en de vraag rijst nu, waar bij Anuren het homologeon van de occ.plaat der Urodelen te zoeken is.

Het alternatief wordt door Gaupp (1893, pg. 357) als volgt geformuleerd :

„1e dieser Abschnitt ist schon in der völlig ausgebildeten Basalplatte, wie sie bei Larven von $15 \mathrm{~m} . \mathrm{M}$. besteht, vorhanden; diese repräsentiere also bereits: Balkenplatte + mesotischen Knorpel + "Occipitalplatte", oder

$2 e$ die Basalplatte dieses Stadiums sei nur: Balkenplatte mesotischen Knorpel, und die Anlagen der erst später verknorpelnden Occipitalbogen hätten mit ihren basalen Theilen die Chorda gar nicht erst erreicht, oder seien doch schon frühzeitig von der Chorda abgedrängt und daher nur mit den seitlichen Theilen der Basalplatte ides mesotischen Knorpels) verbunden."

In het eerste geval zou men moeten aannemen, dat de basis van den occ.boog vóór den boog zelve in kraakbeen zou zijn overgegaan, iets wat met den toestand bij Urodelen en met den aanleg van wervels in het algemeen een tegenstelling zou vormen, daar hier boog en basis gelijktijdig verschijnen.

Meer voelt Gaupp daarom voor de tweede mogelijkheid en hij stelt zich voor, dat bij Anuren door het vooruit schuiven van den eersten wervelaanleg de aanleg van den occ.boog van de chorda wordt opzijde gedrongen en zich verbinden moet met meer zijdelings gelegen deelen van de basaalplaat.

Deze beide opvattingen lijken me niet geheel juist tor.

De eerste niet, omdat, zooals Gaupp zelf mededeelt, ook de basis van den eersten wervel vóór den wervelboog verkraakbeent en we onder invloed van het oorkapsel hier wel afwijkingen in de volgorde van ontwikkeling kunnen verwachten.

De tweede bewering lijkt me een gezochte verklaring, omdat ze a priori een drieledigheid van de basaalplaat wil handhaven, die in de ontogenie niet is aan te toonen. 
Gaupp kan, evenmin als Stöhr, een juiste begrenzing van de occ. plaat aangeven. Wel heeft hij (1893) in de basaalplaat dikteverschillen opgemerkt: het middelste deel van de plaat is lager en ligt meer ventro-lateraal van de chorda dan de beide overige deelen. Maar met evenveel recht zou men, zooals Stöhr feitelijk gedaan heeft en uit zijn afbeelding blijkt (1882, Taf. III, fig. 18), kunnen aannemen, dat dit de overgangsplaats tusschen de twee deelen van de basaalplaat is.

De mededeelingen van Stöhr en Gaupp geven dus geen recht te besluiten tot een drieledige samenstelling van de basaalplaat, zooals bij Urodelen het geval is.

Ook Peeters 1910 houdt op grond van de ligging der myotomen vast aan een basaalplaat uit drie componenten bestaande. Er zijn volgens hem twee myotomen, wier plaats door kraakbeen wordt ingenomen. Het eerste geeft het aanzijn aan het mesotisch kraakbeen; het tweede aan de occ. plaat. Deze occ.plaat, die zich als een wig tusschen chorda en mesotisch kraakbeen inschuift, is af te grenzen van het daarvóór liggende kraakbeen. Caudaal stijgt van de occ.plaat een niet kraakbeenige weefselstrook omhoog naar het oorkapsel.

Dat Peeters een afzonderlijken aanleg van de basis van den occ.boog gezien heeft, is niet verwonderlijk, daar dit theoretisch te verwachten is; de moeilijkheid schuilt in de mededeeling, dat het "eerste" myotoom in kraakbeen overgaat. Daar Peeters de ligging van de myotomen niet door afbeeldingen duidelijk maakt, noch de ontwikkelingsgeschiedenis ervan nagaat, is het moeilijk zich van den gang van zaken een duidelijke voorstelling te maken. Waarschijnlijk moet men het zich zoo voorstellen. Peeters nam waar, wat ik bij Alytes genoemd heb K.S.II en R.S.I; dat hij K.S.I waargenomen zou hebben is uitgesloten ; K.S.II als myotoom is in verband met den toestand bij Bufo niet onwaarschijnlijk. K.S. II wordt evenals bij Alytes door kraakbeen vervangen. Wanneer men nu niet precies de ligging van den occ.boog nagaat ten opzichte van K.S.II en R.S. 1, waaromtrent Peeters niets vermeldt, kan men door de reductie van R.S.1 en door de achterwaartsche uitbreiding der basaalplaat meenen, dat ook R.S.1 in kraakbeen is veranderd en de occ.boog tusschen R.S.1 en R.S.2 gelegen is. 
Deze veronderstelling wint aan waarschijnlijkheid, wanneer men Rana fusca en Alytes in dit opzicht met elkaar vergelijkt.

De occ.boog bij Alytes is van den beginne af goed aangeduid en reeds bij een larve van $5 \mathrm{~m} . \mathrm{M}$. serie 4) in aanleg aanwezig (fig. 9, Pl. II). Bij een larve van $7 \mathrm{~m}$.M. (model) is de ligging zóó duidelijk, dat de niet kraakbeenige boog mee gemodelleerd kon worden. Bij een larve van $91 \%$ m.M. (serie 13 ) is de occ.boog reeds geheel kraakbeenig; in dit stadium is nog geen planum internasale aanwezig. Bij een Rana-larve van $12 \mathrm{~m} . \mathrm{M}$. met goed ontwikkeld planum internasale vond ik het myotoom R.S.1 onder pigmentvorming in reductie en de occ.boog nog slechts aangeduid; bij een larve van $14 \mathrm{~m} . \mathrm{M}$. is van kraakbeenvorming nog geen sprake.

Het is natuurlijk moeilijk vergelijkingen te treffen door af te gaan op de afmetingen der larven, maar dit is wel zeker, dat bij Alytes de kraakbeenvorming in de occ.streek veel sneller en vroeger plaats vindt dan bij Rana !vgl. b.v. ook het model Alytes 7 m.M., waar het oorkapsel even ver ontwikkeld is als bij het model Rana $14 \mathrm{~m} . \mathrm{M}$. van Gaupp, terwijl bij deze reeds het planum internasale gevormd isi. Dit vroege verkraakbeenen van het caudale schedeldeel van Alytes brengt met zich mede, dat de occ.boog reeds zeer vioeg in aanleg te zien is en zijn verhouding tot de myotomen beter bepaald kan worden dan bij Rana. Wanneer bij Rana de voorkraakbeenige occ.boog zichtbaar wordt, is R.S.1 reeds zoover in reductie, dat het den schijn heeft, alsof de occ.boog bij het caudale deel van dit myotoom behoort, terwijl het inderdaad met het voorgaand K.S.II verband houdt.

Voor Rana is dus een hernieuwd onderzoek met nauwkeurige inachtneming van de ligging en atrophie der myotomen en bijbehoorende ganglia en de ontwikkeling van den occ.boog zeer zeker gewenscht.

Het zal wit het bovenstaande duidelijk zijn, dat het voor Anuren niet mogelijk is den term .,mesotisch" kraakbeen te definieeren. Door aan te nemen, dat dit bij Anuren ontbreekt en de basaalplaat uit twee comonenten is samengesteld, de trabekelplaat en de occipitaalplaat, wordt een ongedwongen verklaring gegeven voor hetgeen door Stöhr en Peeters gevonden werd. Beide oncler- 
stellingen van Gaupp blijken niet juist te zijn. Hetgeen door hem en anderen met den naam mesotisch kraakbeen bestempeld wordt, is inderdaad de occipitaalplaat.

De tweeledige samenstelling der basaalplaat bij Anuren, waarop het ontbreken van het derde postotische kopsegment reeds wees, wint ook door hetgeen de ontwikkeling er van leert aan waarschijnlijkheid.

Bij Urodelen is de ontwikkeling der basaalplaat uit drie deelen duicielijk waargenomen. Reeds Stöhr (1880) vermeldt het afzonderlijk optreden van de "occipitalia" bij Triton en Siredon, welke ontstaan na de ontwikkeling van het planum trabeculare, doch vóór de oorkapselvorming (fig. 12, 13, Taf. XXIX). Er zijn spoedig twee deelen te onderscheiden, n.l. het boogdeel en het basale deel, dat terecht occ.plaat genoemd wordt. De occ.plaat ligt achter het oorkapsel en groeit het planum trabeculare tegemoet. De basaalplaat bestaat dus uit twee afzonderlijke gepaarde stukken, waarbij zich later nog laterale deelen voegen, door Stöhr perifeer kraakbeen genoemd. Stöhr geeft een afbeelding, waar dit perifeer kraakbeen ongeveer in het midden tusschen planum trabeculare en occ. plaat op doorsnede bijna het geheele axiale deel der basaalplaat vormt, maar zag in een bepaald stadium niet den afzonderlijken aanleg van dit kraakbeen.

Peeters (1910) meent deze zelfstandige kraakbeenkern gevonden te hebben in een kraakbeenstukje, dat mediaal van het oorkapsel op gelijken afstand van den rostralen rand van den occ.boog en van de trabekelplaat optreedt; het ligt vóor het myoseptum van myotoom 1 en 2 en bereikt spcedig de chorda. Terecht gelooft, Peeters de drieledige samenstelling van de basaalplaat hiermede bewezen te hebben; alleen is het noodzakelijk de beteekenis van dit kraakbeenstukje na te gaan. Met het perifeer kraakbeen van het oorkapsel heeft het volgens Peeters nicts uit te staan $\mathrm{H}_{\mathrm{ij}}$ noemt het dan ook niet perifeer of mesotisch kraakbeen, maar cartilago mediotica. Het ligt ook te ver lateraal van de chorda om het als homologon van de basis van den occ.boog te beschouwen. Toch wijst m.i. de ligging ten opzichte der myotomen (in schema 2 vóór het myoseptum van segm. 2 en 3 1 er op, dat dit kraakbeenstukje verband zou kunnen houden met 
een dergelijken wervelaanleg als die van den occipitaalboog.

Bij Necturus en Amblystoma vindt men ter zelfder plaatse, maar-meer dorsaal, een rest van een wervelboog. Deze praeoccipitaal boog vond Miss Platt (1897. pg. 448) bij Necturus ,in the plane, separating the second postotic somite from the third", als een "rudimentary neural arch, wich is taken into the median wall of the auditory capsule". Bij Amblystoma wordt tusschen het tweede en het derde somiet aangelegd een ,rudimentary praeoccipital arch, which is taken into the auditory capsule" (Goodrich, 1911, pg. 104).

De cartilago mediotica van Triton en de præoccipitaalboog van Amblystoma en Necturus zijn zeer waarschijnlijk resten van een zich onder invloed van het oorkapsel onvolledig ontwikkelenden præoccipitalen wervel.

De drieledige samenstelling van de basaalplaat, die bij Triton volgens Peeters zoo duidelijk aan het licht treedt, schijnt bij Necturus en Amblystoma in de ontwikkeling niet waarneembaar te zijn, maar laat zich theoretisch zeer goed onderstellen.

Voor Ichthyophis onder de Gymnophionen is de samenstelling der basaalplaat door Peter (1898) niet vastgesteld.

Vergelijken- we tenslotte in verband met het bovenstaande nogmaals Urodelen met Anuren, dan is het duidelijk Ivgl. Schema 2), dat de occipitaalboog der Anuren gelijkwaardig is met den praeoccipitaalboog der Urodelen, hetgeen uit de ligging ten aanzien van de postotische segmenten volgt. De praeocc.-boog veronderstelt een praeocc.plaat als wervelbasis en als zoodanig kan bij Urodelen de middelste component der basaalplaat, het mesotisch kraakbeen, beschouwd worden.

De drieledige bouw der basaalplaat voor Urodelen bij Triton aangetoond, is bij Anuren ontogenetisch niet bewezen; theoretisch laten zich hier slechts twee componenten verwachten.

Bij Urodelen vindt men dus een basaalplaat, bestaande uit trabekelplaat, mesotisch kraakbeen (præoccipitaalplaat) en occipitaalplaat.

Bij Anuren wordt de basaalplaat gevormd door trabekelplaat en occipitaalplaat.

In ligging komt laatstgenoemde overeen met het mesotisch kraak- 
been der Urodelen. Toch dient deze term, om verwarring met de oude opratting der uit drie deelen samengestelde basaalplaat te voorkomen, voor Anuren te vervallen.

Dat we Ajij Aruren een schedelaanleg aantreffen, die een segment minder zou bevatten dan die der Urodelen, vindt nog in de volgende overwegingen steun:

1e. Bii Anucen valt steeds of te merken, dat bij den aanleg van den occiplatabogg dicns nerreluature ved minder duidelijk aan den dag treedt dan bif Urodelen. We zien bij de eerte tusschen deoorkapsels een doratal petilgende wedselsireng, die z wh aan het oorkapsel hecht en vertrabbeent; bij Urodclen =ien we den occipitaalboog met hasis duidelith algegrenod en vrij gelegen achter hot oorkapsel (vgl. b.v. Peeters, 1910, Pl. 1, fig. 3 voor Necturus en fig. 2 voor Triton met min model van Alytes 7 m.M., Pl. 1, fig. 1 en 2). 2e. Bij Änuren werd nooit cen precccipitalboog aangetroffen. 3e. Bij Anuren wordt nooit een doorboring van den eersten wervel gevonden 1): dit staat hiermede in verband, dat de eerste ventraie spinale zenuw vrij tusschen wervel $l$ en 2 kan uittreden en niet zooals bij Urodelen op het articulatiepunt van schedel en atlas komt te liggen; larvaal ligt ze bij Urodelen hier nog vrij, maar in den loop der ontwikkeling wordt ze op deze gevaarlijke plaats door kraakbeen omsloten, waardoor de eerste wervel zijn doorboring verkrijgt (De Gaay Fortman, 1918).

te. Men vindt bij vele Anuren een voorbijgaande epichordale continuiteit 'van schedelbasis en eersten wervel (vgl. bij Götte, 1875, fig. 164, 165, 166); zelf nam ik het waar bij Pipa americana (evenzoo Ridewood 1897). Dit zou op een vroegere samenhoorigheid van schedel en eersten wervel kunnen wijzen.

1) Pipa americana maakt een schijabare uitzondering, doch men mag om verschillende redenen iannemen, dat deze wervel een clubbelivervel is: de toestanu is in den grond dezelfde als bij de Anur aphaneroglossa. Howes 11893) nam bij enkele Anuren als abnormaliteit een doorboorden eersten wervel waar; bewezen moet worden of men ook hier niet met een dubbelwervel te maken heeft. Daar hij alleen over skeletten beschikte, kon hij omtrent het zenuwverloop niets naders aangeven. Dat dit van veel belang kan zijn, bewijst Pipa americana (vgl. v. Ihering 1880). 


\section{B. Occipitaalboog.}

Het eerste begin van ontwikkeling van den occipitaalboog vindt men bij een larve van $5 \mathrm{~m} . \mathrm{M}$. (serie 4) als voortzetting van het donker gekleurde parachordale weeisel, dai zich versmalt, lateraal van de chorda albuigt en zwaik dorsaal ombuigend nog slechts over een korten afstand te volgen is. De kernen komen verder uit elkander te liggen en zijn tenslotte van het omliggende mesenchym niet te onderscheiden. Het laatste duidelijke spoor van den toekomstigen occipitaalboog ligt juist vóór het cerste rompmyotoom (R. S. 1) caudaal van gangl. X en op ongeveer een dercie van de hoogte van den caudalen oorkapselwand (zie fig. 10). Er is dus noy geen verbinding met het oorkapsel zelf. Deze vinden we in een larve van 6 m.M. (serie 8), waar het samentreffen van oorkapsel- en occipitaalboog-blasteem caudaal van N.X. goed waar te nemen is. Het parachordale weefsel is hier, evenals in de voorgaande serie, reeds in kraakbeen overgegaan. De aanhechting van den dorso-lateraal ombuigenden boog geschiedt ter halver hoogte van het oorkapsel.

De kraakbeenvorming vindt, behalve in aansluiting bij de basaalplaat, plaats vanuit het raakpunt van boog en oorkapsel. In serie 9 (larve $7 \mathrm{~m}$. M.) ziet men hier kraakbeencellen, welke wel tegen het kraakbeen van den medialen oorkapselwand aanliggen, maar door kerngroepeering daarvan te onderscheiden zijn. Er is dus een grens tusschen beide zichtbaar. De boog zet zich dorsaal niet kraakbeenig in het vliezig hersenkapsel voort.

Bij een larve van $91 / 2 \mathrm{~m} . \mathrm{M}$. is de kraakbeenige verbinding van basaalplaat en oorkapsel tot stand gekomen en het foramen jugulare dus kraakbeenig omgrensd.

\section{LITERATUUR.}

De eerste aanleg van den occipitaalboog bij Rana fusca wordt door Stöhr (1882) niet zeer duidelijk beschreven. In zijn vierde stadium vindt hij „ein undeutlich abgegrenzter Haufen kleiner Zellen" liggen, ,am aüsseren oberen Umfang der Chorda, in dem Winkel, den die oben seitlich von der Chorda etwas abstehenden Muskeln freilassen" (pg. 88). In een later stadium 5 spreekt 
hij van een niet-kraakbeenigen, met cen breede basis lateraal op de chorda gelegen halfboog; hoe de verkraakbeening geschiedt zegt Stöhr nict zeer precies; zeer waarschijnlijk meent hij in aansluiting bij het "mesotisch" kraakbeen.

Gaupp (1893) geeft een beschrijving van den occipitaalboogaanleg bij Rana fusca, welke evenzeer op Alytes van toepassing is. Ook hij merkte op, dat eerst de basaalplaat kraakbeenig wordt, daarna de occipitaalboog. Vandaar dat deze in zijn model niet wordt aangegeven (1893, fig. 1. Taf. XIII; larve 14 m.M.).

Tot hetzelfde resultaat komt ook Peeters (1910).

Eigenaardig is het, dat deze laatstgenoemde bij larven van Rana fusca van 11 en $11 \%$ m.M., wat den occipitaalboogaanleg aangaat, gelijke toestanden aantreft als door mij bij Alytes-larven van 5 en 6 m.M. gevonden werden, hetgeen weer aantoont, hoe snel de ontwikkeling in het caudale schedeldeel bij Alytes verloopt.

Eveneens stemmen beiden overeen, waar ze constateeren, dat de kraakbeenige occipitaalboog versmelt met een kamvormige lijst van het oorkapsel, de crista occipitalis lateralis. De ontwikkeling van den boog geschiedt dus blijkbaar in dorsale richting in aansluiting bij de basaalplaat en wordt door Gaupp voor larven van $21 \mathrm{~m} . \mathrm{M}$. aangegeven. De eerste wervel begint reeds bij larven van $15 \mathrm{~m} . \mathrm{M}$. in kraakbeen over te gaan.

Alytes verschilt in dit opzicht aanmerkelijk van Rana. Reeds bij larven van $9^{1}$ m.M. is de occipitaalboog kraakbeenig, terwijl de eerste wervel eerst bij larven tusschen 16 en 22 m.M. lang optreedt. Voor zoover een vergelijking tusschen larven van verschillende soorten in verband met haar lengte geoorloofd is, zou men hieruit een argument kunnen putten voor de vroegtijdige ontwikkeling van de regio occipitalis bij Alytes ten opzichte van Rana fusca.

Bij Rana geschiedt de ontwikkeling van de occipitaalstreek gelijktijdig met die van den eersten wervel, bij Alytes valt de ontwikkeling van den occipitaalboog geruimen tijd ervoor.

Een zelfstandig kraakbeencentrum, tegen het oorkapsel gelegen, schijnt bij Rana niet voor te komen. Dat het bij Alytes voorkomt, is van belang in verband met de homologisatie met den 
praeoccipitaalboog der Urodelen, die als een dorsaal wervelboogrudiment tegen den medialen oorkapselwand gelegen is.

Een crista occipitalis lateralis komt bij Alytes en deze jonge stadia niet voor. Later treft men haar evenzeer als bij Rana aan.

\section{Chorda dorsalis.}

Wanneer we de ligging der chorda in zeer jonge stadia nagaan ten aanzien van infundibulum en gehoorblaasjes, is het opmerkelijk, dat deze zich aanvankelijk niet zoover rostraal uitstrekt als men verwachten zou.

In een larve van $4 \frac{1}{2}$ m.M. (serie 2) ligt de chordapunt tusschen de gehoorblaasjes, maar bereikt de lijn, die hun midden verbindt, niet (fig. 6, Pl. II). Er blijft een groote afstand tusschen infundibulum en chordapunt.

Een voor dat doel vervaardigde sagittale doorsnede van ecn nog jonger stadium (serie 1 , larve $41 \%$ m.M.) deed dit eveneens duidelijk uitkomen.

In oudere stadia ziet men de chorda zich steeds verder rostraal uitstrekken. Bij een larve van 5 m.M. (serie 3) wordt de middellijn der gehoorblaasjes bereikt, bij een larve van 5 m.M. (serie 4) overschreden (fig. 10, Pl. II) en is eveneens de afstand tot het infundibulum verkort. Bij een larve van $6 \mathrm{~m} . \mathrm{M}$. (serie 5) treedt het eerste kraakbeen in het parachordale weefsel op. De punt van de chorda reikt nu tot even voorbij het oorkapsel en tot dicht bij het infundubilum. Er ligt nog geen kraakbeen vóor de chordapunt. Deze is halfbolvormig evenals in de twee volgende stadia, larven van 6 en $6 \%$ m.M. (serie 6 en 7), waar nu ook kraakbeen vóór de chordapunt wordt aangetroffen (fig. 12, Pl. II). De primaire chordascheede is volkomen intact. De kraakbeencellen rondom de punt zijn gerangschikt als de cellen van een wortelmutsje om den worteltop.

In serie 9 (7 m.M.) blijkt uit dwarse doorsneden, dat de chordapunt flauw dorsaal is omgebogen; vandaar dat de uiterste top op 1/:; van de hoogte van de basaalplaat eindigt. Vóór de chorda ligt kraakbeen, dorsaal en ventraal nog niet. Wel treffen we dorsaal een in caudale richting steeds dunner wordend, uit ge- 
rekte cellen hestaand, donker gekleurd prochondraal weefsel aan, dat arm liit hij en overgaat in het parachordale kraakbeen; ventraal ligt de chorda vrij, behoudens het meest craniale deel, waar de punt omhoog buigt. Hier vereenigen zich beide parachordaalplaten door voorkraakbeenig weefsel, hetgeen in een volgend stadium in kraakbeen is overgegaan.

In een larve van $7 \mathrm{~m} . \mathrm{M}$. (serie 9) is de chordapunt nog normaal. Reductieverschijnselen treden eerst op in larven van $81 \%$ m.M. (serie 11 en 12).

\section{LITERATUUR.}

Als regel strekt de chorda der Anuren zich aanvankelijk tot het infundibulum uit (vgl. voor Bombinator Götte, 1875, Taf. XVI, fig. 292, 293.294 en Taf. XVII, fig. 304; voor Hyla Stöhr, 1882, fig. 14, Taf. II).

Waar dit bij Alytes niet het geval is, moet dit als een uitzondering worden beschouwd en aan zeer vroegtijdige reductie worden tocgeschreven. Volgens Bergfeldt (1897) liggen bij Alytes in een stadium ( 14 myomeren), waarin de chorda nog niet gevacuoliseerd is, tusschen de chordapunt, die zich uitstrekt tot dicht achter het gehoorblaasje en de basis van den ,,mittleren Schäcielbalken" (--Mittelhirnpolster, Gaupp, 1906) celcomplexen, die afkomstig zijn van de vroeger tot dit punt reikende chorda.

Onder de Amphibia heb ik in de literatumr slechts één parallel geval angetrollen, nl. voor N'ecturus bij Buchs (1901), waar volgen: lig. 19, Taf. XXVII, in een sagittale doorsnede, naar de beschrijvirig ongeveer door het midken gevoerd, een overeenkometige ligging der chorda in een iong stadium $(13 \mathrm{~m}$. M.). te zien is. Bevestigd werd dit dror hetyeen Evcleshymer and Wilson (1910) omtrent de chorda van Necturus mededmelen, waaruit blijkt, dat hier de ligging van de chordapunt ten opzichte van de hypophyse varieert.

T: nslotte ligt bij Alytes de chordapunt slechts weinigy caudaal van de plaats, waar zij te verwachten is. Dit wordt door het ongelijh uitgroe:en der weefsels en organen in het kop-en rompgedeelte veroorzaalit en zooals bijna vanzelf spreckt niet door een secundair actief uitgroeien van de chorda zelf, 
De ligging der trabekelplaat ten aanzien van de chorda varicert. Stöhr (1882) vindt, dat deze bij Rana niet tegen de chordapunt maar meer caudaal gelegen is (fig. 13, Taf. II). Bij de vorming van het ongepaard planum trabeculare wordt de chordapunt van boven en onderen omgroeid en degenereert. Hetzelfde vindt hij ook voor Pelobates. Bij Bufo cinereus treedt de vereeniging het eerst onder de chorda op door een dikke commissuur en dan eerst ervoor; de bovenzijde blijft vrij. Bij Hyla geschiedt dit juist andersom: eerst vereeniging boven de chordapunt en dan ervoor.

De wijze van omgroeiing varieert dus bij verschillende genera, maar ook bij dezelfde species is deze niet constant: Gaupp (1893), die de chorda bij Rana dorsaal het eerst zag overgroeien, vond bij verschillende larven ook wel ventrale overgroeiing en de chorda dorsaal onbedekt. Rana esculenta schijnt volgens Peetẹrs (1910) een uitzondering te maken, daar hier de chordapunt in kraakbeen verandert en niet verdrongen wordt.

Hoe dit allereerste verdringen van de chordapunt bij Rana plaats vindt, wordt door geen der auteurs beschreven. Uit enkele series van Rana fusca-larven van $7 \%$ en $12-14$ m.M., in verschillende richting gesneden, bleck mij, dat de chordapunt dorsaal overgroeid wordt door het kraakbeen van het planum trabeculare. De oorspronkelijk stompe chordapunt wordi door het gelijktijdig van de zijden opdringende kraakbeen saamgedrukt tot een gerekt? scherpe punt, waarin pigment en dooierkorrels aanwezig zijn. Er blijft tenslotte niets dan een dun, verticaal saamgevouwen blad over, dat in het kraakbeen opgenomen wordt.

Al deze veranderingen ziet men bij Alytes niet, daar hier van den aanvang tusschen het infundibulum en de chordapunt ruimte overblijtt, waardoor het mogelijk is, dat de trabekelplaten zich vóór de chordapunt kunnen vereenigen (zie fig. 10 en 12, P1. II', zonder dat de chorda op eenige wijze verdrongen behoeit te worden. Het is dus niet te verwonderen, dat de chordapunt in larven van $7 \mathrm{~m} . \mathrm{M}$. nog geen reductieverschijnselen vertoont.

Onder de tot heden in dit opzicht onderzochte Anuren neemt Alytes dus een bijzondere plaats in. 


\section{B. CAPSULA AUDITIVA.}

\section{Stadium I.}

De ontwikkeling van het vliezige labyrint komt in dit stadium overeen met hetgeen Gaupp 11893) beschrijft voor een larve van Rana fusca van 14 m.M. De drie canales semicirculares hebben zich reeds afgezonderd van den thans nog één ruimte vormenden utriculus eu sacculus (cavum utriculo-sacculare). Het is dan ook niêt te verwonderen, dat, waar er een zekere relatie bestaat tusschen de mate van ontwikkeling van het vliezige labyrint en het kraakbeenige oorkapsel, dat het omkleeden zal, ook het oorkapsel zelf in dit stadium groote overeenkomst vertoont met het eerste model van Gaupp (1893, fig. 1, Taf. XIII).

Het oorkapsel is nog slechts gedeeltelijk verkraakbeend; de mediale wand ontbreekt geheel, de dorso-laterale afsluiting gedeeltelijk en ook het primaire ovale venster is zeer ruim.

De canalis semicircularis lateralis is lateraal geheel met kraakbeen bekleed, dat aldus een verbinding tot stand brengt tusschen de cupula anterior en posterior. De canalis semicircularis anterior en posterior zijn dorsaal nog maar over een kleinen afstand met kraakbeen bedekt, dat eveneens aansluit bij de cupula anterior resp. posterior.

Een commissura basicapsularis anterior als verbinding tusschen periotisch kraakbeen en basaalplaat is nog slechts uiterst zwak ontwikkeld en door weinige, min of meer verspreid liggende kraakbeencellen vertegenwoordigd; de commissura basicapsularis post. daarentegen is goed ontwikkeld. Ter plaatse van het ganglion acusticum vertoont de ventrale oorkapselwand een dorsale verdikking, die het genoemde ganglion draagt (fig. 1, Pl. II).

De mediale wand van het primaire ovale venster, die niet door de basalplatt, maar door het oorkapsel zelf gevormd wordt, is niet scherp begrensd, dooriat de kraakbeenvorming daar in vollen gang is; vandaar ook de eenigszins grilige vorm. Dit zelfde geldt ook voor den rostralen, caudalen en lateralen rand.

\section{Ontwikkeling.}

In een larve van $6 \mathrm{~m} . \mathrm{M}$. (serie 6) wordt het eerste kraakbeen rostraal en caudaal in de ventrale helft van het toekomstige 
oorkapsel aangetroffen. De cupula ant. en post. verkraakbeenen het eerst, terwijl in dit stadium nog geen kraakbeen om den canalis semicircularis lateralis gevonden wordt, behalve in het rostrale deel om de ampulla lateralis. Dit kraakbeen sluit bij dat van de cupula ant. aan. De cupula post. is in ontwikkeling bij de cupula ant. ten achter.

In een larve van $6 \frac{1}{2} \mathrm{~m} . \mathrm{M}$. (serie 7) is de toestand in het rostrale deel van het oorkapsel dezelfde gebleven, maar caudaal heeft de cupula post. zich medio-ventraal uitgebreid, zonder evenwel de basaalplaat te bereiken.

Het kraakbeen om den canalis semicircularis lateralis is in een larve van $7 \mathrm{~m} . \mathrm{M}$. (serie 8) vanuit het ampullaire gedeelte caudaal uitgegroeid; ongeveer halverwege; ter hoogte van den saccus endolymphaticus, verliezen de kraakbeencellen haar duidelijkheid. De medio-ventrale voortzetting van de cupula post. hecft zich onder de macula sacculi uitgebreid en is te vervolgen tot even voorbij de caudale begrenzing van ganglion VIII. Er is nog geen verbinding met de basaalplaat tot stand gekomen. De commissura basicapsularis ant. is nog niet kraakbeenig, de commissura basicapsularis post. daarentegen wel.

We zien in het oorkapsel dus twee punten, van waaruit de kraakbeenvorming plaats vindt:

1e. De cupula anterior, die waarschijnlijk het eerst in kraakbeen overgaat en van waaruit in caudale richting de laterale kraakbeenstrook om den canalis semicircularis lateralis gevormd wordt, die de cupula post. bereikt en er mee versmeit (serie 9). 2e. De cupula posterior, van waaruit in rostrale richting het oorkapsel medio-ventraal begrensd wordt, welk kraakbren zich aanlegt tegen dat van de basaalplaat en er mede vergroeit, zoodat in latere stadia (serie 11 en 12 , larven $8^{1}$., en $91 \%$ m.M.) een grens tusschen beide niet meer valt aan te geven.

De commissura basicapsularis posterior ontwikkelt zich vóór de commissura basicapsularis anterior.

\section{LITERATUUUR.}

Over de eerste kraakbeenvorming in den oorkapselwand vindt men in de literatuur slechts weinig vermeld. 
Götte (1875) zag bij Bombinator lateraal reeds kraakbeen in het oorkapsel optreden, roordat nog het middengedeelte van de schedelbasis was aangelegd. Door het merlial uirgroeicn van dit laterale deel komt de verbinding met de hesaalplaat tot stand. Vandaar zijn opvatting, dat het oorkapsel cen afzoncierlijk zintuigkapsel is.

Stöhr (1882) trof bij Rana het eerste kraakbeen in het laterale deel van het kapsel om den canalis semicircularis lat. aan; dit kraakbeen is oorspronkelijk geisoleerd van het planum trabeculare en het mesotisch kraakbeen, maar later komt een verbinding tusschen beide tot stand. In verband met den vliezigen (niet kraakbeenigen!) samenhang van dit laterale kraakbeen met het mesotische, meent hij, hoewel hij toegeven moet, dat de oorkapsels bij Anuren zelfstandig verkraakbeenen, het oorkapsel tot het mesotisch weefsel te mogen rekenen.

Gaupp (1893) neemt voor Rana fusca twee punten van kraakbeenvorming aan:

1e. Vanuit het parachordale kraakbeen wordt het medio-ventrale deel omsloten en 2e. van uit de periferic van den canalis semicircularis lat. wordt door craniale en caudale uitbreiding het kraakbeen om cupula ant. en post. gevormd en in aans!uting daarmede komt ook de verbinding door beide commissuren met de basaalplaat tot stand.

In hoeverre nu het periotisch gevormde kraakbeen aan de mediale begrenzing van het ovale venster deelneemt en waar de grens tusschen het mesotische, van uit de chorka ontstane en het periotische kraakbeen precies valt, kon Gaupp niet met zekerheid aangeven.

Peeters (1910) had jongere stadia dan Gaupl) tot zijn beschikking. Op grond van zijn preparaten van Rana fusca en esculenta sluit hij zich bij de veronderstelling van Gaupp aan, dat he: periotisch kraakbeen geen deel heeft aan de mediale begrenzing van het primaire ovale venster, maar dat het hier gelegen kraakbeen zich in caudate riching vanuit het parachordale kraakbeen zou ontwikkeld hebben. Een kraakbeenstrookje lateraal van de myotomen en mediaal van het onrkansel ontstaat het eerst en strekt zich uit tot onder de proximale grens van den rand der cupula 
post., rostraal tot het planum trabeculare. In den dorso-lateralen rand van den canalis semicircularis lat. ontstaat in het corkapsel zelf het ecrste kraakheen, dat zich langs het kanaal caudaad voortzet en vóór de cupula post. zich ventraal met genoemd strookje verbindt; aldus ontstaat de commissura basicapstilaris post., eerder dan de commissura basicapsularis ant.

Vergelijk men nu het bovenstaande met het bij Alytes gevondene, dan vindt men een voornaam punt van onderscheid in het feit, dat bij Alytes het eerste kraakbeen niet zooals bij Rana, Bombinator e.a. in het oorkapsel rondom den canalis semicircularis lat. ontstaat. Deze afwijking treft te meer, daar ook voor Urodelen wordt opgegeven, dat rondom het laterale boogkanaal het eerste kraakbeen gevonden wordt (Stöhr, 1880, 1882; Gaupp, 1906).

Belangrijker is de vraag naar de herkomst van hei kraakbeen, mediaal van het primaire ovale venster gelegen.

De ontwikkeling bij Alytes wijst op een secundair verband met het kraakbeen van de basaalplaat en liet een vooruitschuiving in craniale richting vanuit de cupula post. zien. Deze opvatting komt met die van Götte tot op zekere hoogte overeen, mar is in tegenspraak met de meening van Stöhr, Gaupp en Peeters. Alleen de laatste dient in dit verband nader besproken te worden, daar Stöhr's argument van de vliezige verbinding tusschen mesotisch en periotisch kraakbeen van weinig waarde is, en Gaupp slechts een veronderstelling waagt, zonder uit directe waarneming iets te kunnen bewijzen.

Tenslotte komt de kwestie hierop neer: moet het kraakbeenstrookje, door Peeters mediaal van het oorkapsel waargenomen, gerekend worden tot de basalplaat of niet. Het eersie wordt door hem niet aangetoond en m.i. is de veronderstelling even zeer gerechtvaardigd, dat wij hier een vroe; tijd g verkraakbenend deel van den oorkapselwand roor ons hebben, dat cerst secundair met het kraakbeen, dat op de plaats van zijn myot. 1 en 2 komt te liggen en de eigenlijke basaalplaat vormt, versmelt.

Wanneer dit krakbeenstrookje werkelijk tot hei oorkapsel mag gerekend worden, is ook bij Rana de mediale rand van het ovale venster hiervan afkomstig en liggen de verschillen tusschen 
Rana en Alytes in den tijd wanneer en de plaats waar het eerste kraakbeen zich vertoont.

Voor Alytes zou men de vraag of het gehoorkapsel een zelfstandig zintuigkapsel is. dat eerst secundair met het axiale schedelkraakbeen vergroeit, bevestigend moeten beantwoorden. Immers de oorkapselwand wordt hier niet door een lateraal en een van de basaalplaat afkomstig deel gevormd, maar beide kraakbeencentra behooren tot het oorkapsel zelf. Bij het rostrale cupulaire deel sluit zich het kraakbeen om het lateraa!-kanaal aan ; bij het caudale het secundair met de basaalplaat versmeltende medio-ventrale kraakbeen.

\section{REGIO ORBITALIS.}

\section{Stadium I.}

De kraakbeenige trabeculae, die caudaal in het ongepaard planum trabeculare overgaan. omgrenzen de hersenen ventro-lateraal Uvormig, doch hebben zich rostraal nog niet door het planum internasale vereenigd. We kunnen dus in dit stadium nog niet van een fenestra basicranialis anterior spreken.

Met het palatoquadratum is caudaal en craniaal door middel van den processus ascendens. resp. commissura quadrato-cranalis anterior een kraakbeenige verbinding tot stand gekomen. De proc. ascendens bereikt de trabekel onder een hioek van $=70$.

Hier ter plaatse is de reeds gedeeltelijk kraakbeenige zijwand door een zeer dun kraakbeenstrookje met de sterk verhoogde trabekel verbonden (flg. 1, Pl. II).

De schedelwand en het dak verkeeren nog in het .,vliezige" staditm, uitgezonderd het genoemde gedeelte, waarin zich kraakbeen tot voor den N.II laat aantoonen. In den deels vliezigen, deels kraakbeenigen zijwand zij. twee openingen voor den N.III en II uitgespaard, die beide door een nog viezigy deel van den zijwand gescheiden zijn. De N.III verlaat de hersenholte door den caudalen bovenhoek van het foramen oculomotorii; in den ventro-caudalen hoek treedt de arteria ophthaimica. een zijtak van de arteria carotis interna, naar buiten. Het foramen oculomotorii is in verhouting tot den zeer dunnen N.Iil ruim te noemen. De opening wordt groutendeels door de hier samenkomende oug- 
spieren gevuld, die zich aan het verhoogde trabekeldeel, waarmede de processus ascendens samenhangt, hechten.

Ook het foramen opticum, dat caudaal juist den N.II omgrenst, laat dorsaal en craniaal nog ruimte over. De ventrale trabekelbegrenzing is kraakbeenig; dorsaal is de zijwand nog maar voor een deel in kraakbeen overgegaan, de overige grenzen zijn nog vliezig.

De trabeculae krijgen craniaal van den N.II een meer driehoekige doorsnede: de dorsale en ventrale scherpe hoeken zetten zich voort in het vliezige oorkapsel, terwijl de laterale stompe hoek weldra in de commissura quadrato-cranialis ant. overgaat. Rostraal van deze commissuur gaan de trabeculae meer en meer het ventro-laterale deel der hersenen tegrenzen. De diameter wordt steeds kleiner en de vorm meer in de leıgte gerekt, echter zonder dat beiderzijds de trabeculae nog met elkander in verbinding treden door de vorming van het planum internasale.

De ventrale afsluiting der hersenhclte wordt door een vliezige verbinding der trabeculae gevormd, waarin beiderzijds de opening voor de intredende arteria carotis, het foramen caroticum primarium, ter hoogte van den proccessus ascendens juist tegen de ventro-mediale zijde van de trabekel ligt. Het foramen craniopalatinum is nog niet scherp begrensd. Ter hoogte van den N.II verlaat de ramus palatinus van de arteria carotis interna door dit foramen de schedelholte. Een for. N. IV is in den schecielzijwand nog niet aan te toonen.

Tusschen corkapsel en zijwand ligt het ganglion proöticum, dat gedeeltelijk op den processus ascendens steunt. Dorsaal wordt het ganglion omsloten door het vliezig hersendak, dat zich met het oorkapsel verbindt.

\section{Ontwikkeling.}

De U-vorm van planum trabeculare en trabeculae is reeds in de niet kraakbeenige stadia door dekernophooping in het voorkraakbeenige weefsel tegenover het losse omliggende mesenchym scherp afgeteekend. Op horizontale doorsneden ziet men, hoe de beenen van de $U$ craniaal smaller worden en ter hoogte van het reukorgaan nog maar enkele cellen dik zijn. Dezen aanleg der trabeculae nam 
ik bij cen larve van $5 \mathrm{~m} . \mathrm{M}$. (serie 4) voor het eerst waar in samenhang met is nog vónkraakbeenige parachordaalplaat. De kraakbeenvorming der trabekels schrijdt in craniale richting voort, beginnend bij de trabekelplaat. Bij een larve van 6 m.M. (serie 5 en 6) vindt men kraakbeen tot op de plaats, waar de N. opticus de trabekel kruist, terwijl men bij een larve van $61 / 2$ m.MI. (serie 7) dit tot dicht bij het reukorgaan kan aantreffen.

In deze dric leatotgencemde tadia is de trabelelaanleg tot vóor het reukorgaan te vervolgen, waar de aanleg der cornua zichtbaar is. In serie 4 is het distale deel van den cornua-aanleg min of meer iffums. De groot dichtheid der opecnliggende chondrobla-tumcell. $n$ an de trabekeis vindr men in deze serie caudaal: craniat neent :a y leidelijk al. Hieruit en ut de richting, waarin de Wrakhernvorminy plaats vindt. meen ik te mogen afleiden, dat de trabekelaanleg van achteren naar voren zichtbaar wordt in aansluiting bij den aanleg van de parachordaalplaat. Parachordaalplaat en trabekel zijn naar alle waarschijnlijkheid noch in a anleg. noch kraakbeenig gescheiden.

Gelijktijdig met het kraakbeenig worden van de parachordaalplat en trabekels (serie 5 en 6) ziet men ook de trabekelverhooging, warruede de nog niet kraakbeenige processus ascendens samenhangt, chondrificeeren. In opvolgende horizontale doorsnedizn neemit de aanvankelijk ronde doorsnede van dit uitsteeksel. dat tot aanhechting der oogspieren dient ivgl. fig. 12, Pl. II), in diameter af, om over te gaan in den voorkraakbeenigen aanleg van den zijwandpijler, die het caudaal verdikte deel van den nog .vliezigen" zijwand uitmaakt.

De kraakbeenvorming der trabekelverhevenheid gaat in dorsale richting voort, zoodat in serie 7 (larve $6 \%$ m.M.) reeds een deel van den zijwandpijler kraakbeenig is; de zijwandaanleg sluit zich bij dezen pijler, die slechts dat deel van den zijwand representeert, dat het eerst kraakbeenig wordt, aan en neemt rostraal in dikte en duidelijkheid af (fig. 12. Pl. II. Dit komt wederom overeen met de richting. waarin de kraakbeenvorming in den zijwand geschiedt, daar deze rostraal verloopt, als voortzetting van den zijwandpijler. Dit eerste zijwandkraakbeen vindt men bij een larve 


\section{STELLINGEN.}

I.

De clavicula der Zoogdieren bevat geen procoracoidelementen.

II.

Het sternum van Vogels en Zoogdieren onstaat onafhankelik van de schoudergordel en van de ribben.

III.

Onder de Europeese Joden dient men, uit anthropologies gezichtspunt, twee verschillende typen te onderscheiden.

IV.

Agonale thrombi komen tot stand door stolling en thrombose. 

$\operatorname{van} 7 \mathrm{~m} . \mathrm{M}$. (serie 8). Op dwarse doorsnede is de zijwandaanleg in het middengedeelte het dikst: dit is ook de plats waar de eerste kraakbencellen zichtbaar worden. De kraakbeenige zijwand zet zich voort in het vliczige hulsel, dat de hersenen omgeelt en zich caudaal over teet ganglion proöticum met het oorkapsel verbindt.

\section{LITERATUUR.}

De aanleg der trabeculae wordt bij Rana volgens Stöhr '1882, en Spemann (1898) van voren natr achteren duidelijt. In overeenstemming hicmede zict Spomann den antey van de commissura quadrato-cranialis anterior vroeger dan die van den processus ascendens optreden tiy. 17. 1al. 29. Mij I'riton cristatus vond Stöhr 1880 en 1882 cen trabelielemeng ils bij Rana, die in caudale riching voortschrijdt en onsprontelitk niet in verbinding staat met de trahekelplact, geliik dit ook voor sommige Selachii Ganoiden, Teleostei en Vogels (Gatpp, 1906) wordt opgegeven. Voor Alytes kon ik den allereerston aanleg der trabekels niet nagaan, daar deze in een stacium tusschen dat van serie 3 en 4 gelegen, moet aangetroffen worden. Te oordeelen naar de sterke ontwikkeling van het caudale deel van den trabekelaanleg in serie 4, komt het me voor, gelijk reeds op pg. 54 werd gezegd, dat bij Alytes de aanleg in rostrale richting duidelijk zal worden, te beginnen bij het voorkraakbeen vain het planum trabeculare. Hiervoor spreekt ook de wijze van kraakbeenvorming, die in overeenkomstige richting plaats vindt. Hoe dit bij Rana geschiedt wordt door geen der auteurs nacer aangegeren, waarschijnlijk zal de trabekel in caudale richting kraakbeenig worden, in overeenstemming met den eersten aanleg. Voor Triton vulgaris meent Peeters (1910) uit het kleurverschil, dat het kraakbeen der trabekels na methyleenblauwkleuring vertoonde, te mogen besluiten, dat dit het eerst in het midden der trabekels optreedt en zich naar beide zijden ontwikkelt.

De zijwandpijler door Gaupp (1893) in zijn chondrocranit:mmodel van een Rana-larve van $14 \mathrm{~m}$.M. zoo duidelijk aangegeven als een kraakbeenige verheffing op de vereenigingsplaats van trabekel en processus ascendens, vindt men bij Alytes als een caudale verdikking van den nog niet kraakbeenigen schedelzijwand terug 
(fig. 2, Pl. II). Het is ook bij Alytes een voortzetting van het verhoogde deel van de trabekel, waarmede de processus ascendens samenhangt. Uit de opgaven van Stöhr (1882) blijkt, dat deze trabekelverhevenheid bij Rana het hoogste, bij Pelobates minder hoog, bij Bufo en Hyla niet of bijna niet aanwezig is (vgl. Taf. III, resp. fig. 21, 20 en 19!. Wanneer men aan de opvatting van Gatipp (1893, pg. 409, vasthoudt, dat "die Seitenwandpartie nichts weiter sei als der nach oben erhöhte Trabekel selbst", is het duidelijk, waarom de processus ascendens nu eens direct met de trabekel Bufo, Hyla), dan weer met den zijwand (Rana, Alytes! schijnt samen te hangen en de zijwandpijler juist vanaf het verhoogde trabekeldeel bij Rana en Alytes zijn oorsprong neemt. In sommige doorsneden van Alytes (serie 8, fig. 15, Pl. IV) is het inderdaad alsof de processus ascendens zich tegen den zijwand aanlegt. Het is dan ook de meening van Stöhr en Gaupp. dat we tusschen trabekel en zijwand geen scherpe tegenstelling moeten zoeken. Bizonder duidelijk komt dit uit in het op doorsnede gerekte deel van de trabekel ter hoogte van de commissura quadrato-cranialis ant. gelegen, dat ook bij Alytes ventrolateraal de herscnholte begrenst. Het oorspronkelijk verschil in grootte van trabekel- en zijwandkraakbeencellen, dat later in de ontwikkeling verdwijnt, wordt voldoende door den vroegtijdigen aanleg der trabekels verklaard en kan niet als argument gelden om in zijwand en trabekel verschillende vormingen te zien. Ook de invloed der foramina voor den N. II en III als vertragende factor voor de kraakbecnvorming moet niet onderschat worden 1). Het kraakbeen in den zijwand is bij Alytes reeds aan te toonen vóórdat de kraakbeenige verbinding van palatoquadratum en trabekel door den processus ascendens plaats vindt, hetgeen bij Rana volgens Peeters (1910) eerst daaina geschiedt.

Bij Rana zet zich volgens Gaupp (1893) en Peeters (1910) de zijwandpijler in een smal kraakbeenbandje, de "dorsale Randspange"

1. Het s rvegtijdig kraakbeenig worden van de trabekelverhevenheid (het zijwandgedeelte', waarmede de processus ascendens verbonden is, vindt naar alle waarschijnlijkheid zijne verklaring in het feit, dat hier ter plaatse oogspieren aangehecht zijn. De deelen van het kraakbeenig hersenomhulsel, die het eerst voor stevigheid of bevestiging in functie moeten treden, worden het snelst aangelegd en kraakbeenig. 
voort, na door een rostrale verbreeding eerst den $N$. III nauw omsloten te hebben. Dit smalle kraakbeenbandje ontmoet een dergelijke kraakbeenspang, die zich vanuit de verhevenheid tegenover de commissura quadrato-cranialis ant. ontwikkelt (Peeters). Deze ontwikkeling valt bij Rana in larven tusschen 23 en $30 \mathrm{~m}$. M. (Gaupp).

Bij Alytes ziet men reeds vroegtijdig (larve van $7 \mathrm{~m} . \mathrm{M}$.) lateraal een vrij breeden kraakbeenband optreden, die zich in rostrale richting ontwikkelt. Van een smalle "dorsale Randspange" kan men hier moeilijk spreken. De kraakbeenige rostrale begrenzing van het ruime for. oculomotorii heeft eerst op een later stadium plaats.

\section{REGIO ETHMOIDALIS, SUPRAROSTRALIA.}

\section{Stadium I.}

De gerekte vorm, dien de dwarse doorsnede der trabecula ter hoogte van de commissura quadrato-cranialis anterior bezit, blijft over den afstand, waarover de trabekel tusschen hersenen en reukorgaan besloten ligt, bewaard; de trabekels buigen zich hier dichter naar elkander toe en begrenzen de hersenen meer ventraal. Tenslotte hernemen de trabekels op dwarse doorsnede weer den rond-ovalen vorm, wanneer ze niet langer op de zooeven aangegeven wijze ingesloten worden en nu ventraal van de hersenen en mediaal van het reukorgaan vrij komen te liggen. Deze terminale trabekeldeelen, de cornua trabeculae, naderen elkander en buigen eindelijk vrij plotseling, nog caudaal van den voorrand der hersenen, verticaal naar beneden. In het distale deel der cornua wordt het kraakbeen steeds moeilijker te herkennen en vindt men den overgang naar de voorkraakbeenige suprarostralia. Deze sluiten zich ongemerkt bij de cornua aan, buigen caudaal om tot de mondrand bereikt wordt en zetten zich lateraal hier langs voort als een zeer dunne weefselstrook, die weldra weer breeder wordt en in een caudalen, driehoekigen vleugel overgaat, welke zich tot aan den mondhoek uitstrekt. Ook dit deel is nog in voorkraakbeenigen toestand. De vorm der suprarostralia teekent zich duidelijk af tegen het omringende weefsel; vandaar dat deze in het model aangegeven konden worden (fig. 1 en 2, Pl. I). 
Of de suprarostralia zich rostraal voor den mondrand in het midden vereenigen, valt bij deze serie niet met zekerheid uit te maken.

Een ligamentum intertrabeculare superius en inferius ontbreekt.

\section{Ontwikkeling.}

Den eersten aanleg der cornua trabeculae vindt men bij een larve van $5 \mathrm{~m} . \mathrm{M}$. serie 4 , terwijl de suprarostralia hier nog niet aan te toonen zijn. Bij een larve van $6 \mathrm{~m} . \mathrm{M}$. serie 6) zijn de cornua reeds scherp afgeteekend en buigen ze zich ventraal om, overgaand in het weefsel der toekomstige suprarostralia, dat zich over den mondrand als een donker gekleurde weefselstrook tot in de mondhoeken uitbreidt. De mondrand wordt omgrensd door een continue kernverdichting, hetgeen vooral duidelijk is bij larven van $6 \frac{1}{2}$ en $7 \mathrm{~m} . \mathrm{M}$. (serie 7 en 8). De beide suprarostralia zijn derhalve in aanleg vereenigd. Bij de kraakbecnvorming (larve $12^{1} / 2$ m.M.) blijft het middengedeelte der suprarostralia het langst in voorkraakbeenigen toestand.

De aanleg der cornua trabeculae gaat ongemerkt over in dien der suprarostralia. Eerst later bij de kraakbeenvorming, die in de laterale vleugels der suprarostralia begint, worden beide door een niet-kraakbeenige weefselstrook, waarin de kernen dicht opeen liggen, gescheiden.

We zien derhalve, dat bij Alytes de aanleg der trabekelhoorns vooraf gaat aan dien der suprarostralia. Hetzelfde geldt ook voor de kraakbeenvorming. De suprarostralia hebben een eigen lateraal gelegen kraakbeencentrum.

\section{LITERATUUR.}

Wanneer men de afbeeldingen van de jonge stadien van Bom binator (Götte, 1875, Taf. XVIII, fig. 423) en Rana IStöhr, 1882. Taf. III, fig. 18; Gaupp, 1893, Taf. XIII, fig. 1), vergelijkt met het schedelmodel van een larve van Alytes van 7 m.M., dan treft het, dat bij deze eerstgenoemde reeds vóór of gelijktijdig met het tot stand komen van het ongepaarde planum trabeculare ook het planum internasale gevormd wordt. Bij Alytes zien we eerst later llarvenstadia tusschen $91 / 2$ en $12 \frac{1}{2}$ m.M.) het planum internasale optreden, wanneer de basaalplaat reeds geruimen tijd ontwikkeld is. 
De genetische samenhang van trabekelhoorns en suprarostralia werd door Stöhr (1882, en Spemann (1898) ook voor Rana gevonden, zoodat eerstgenoemde tot de opvatting komt, dat de suprarostralia afgesnoerd zouden zijn van de trabekelhoorns en het bewijs geleverd acht, dat ze als een gewijzigd voorste deel der hoorns zijn op te vatten.

Spemann gaat met deze conclusie niet accoord. Terecht zegt hij, dat de homocontinuiteit van een voorkraakbeenigen aanleg nog niet mag doen besluiten tot werkelijke genetische eenheid. Ook het hyoid bv. is oorspronkelijk bij Rana met het quadratum één.

Voor de opvatting, dat de suprarostralia een zekere zelfstandigheid niet ontzegd mag worden, pleit hetgeen Spemann bij Rana vond, dat $\mathrm{nl}$. de aanleg der suprarostralia reeds als een hoopje dicht opeen gelegen cellen zichtbaar wordt, voor er nog iets van de trabeculae te zien is. Ook het zelfstandige laterale centrum, van waaruit het kraakbeen zich ontwikkelt naar de cornua trabeculae toe, geeft aan zijne opvatting steun. Een zelfstandig lateraal kraakbeencentrum wordt bij Alytes eveneens gevonden.

Er zijn echter twee verschilpunten met Rana. Ten eerste wordt de aanleg der trabekelhoorns zichtbaar vóór dien der suprarostralia en ontwikkelen deze zich in aansluiting bij eerstgenoemde; de trabekels verkraakbeenen het eerst. En ten tweede zijn de suprarostralia in aanleg in het midden vereenigd; door de chondroficatie in caudolaterale-rostromediale richting blijft het middenstuk het langst voorkraakbeenig.

Het eerstgenoemde zou als een argument kunnen gelden voor de genetische eenheid van suprarostralia en cornua trabeculae, wanneer men bij de larven van Alytes de voor een Anuur abnormale beginperiode der ontwikkeling niet in het oog moest houden 1). We zien in tegenstelling met Rana het rostrale schedeldeel in ontwikkeling achterblijven bij het caudale. Bij Rana is dit rostrale deel in ontwikkeling vooruit en schijnt deze vroegtijdige aanleg verband te houden met het vroegtijdig functioneeren

1) Door Vogt (1842, volgens opgave van Héron-Royer en van Bambeke, 1889) wordt de late aanleg der hoornkaken bij Alytes op overeenkomstige wijze verklaard. 
der hoornkaken. Of dus de ontwikkelingsgang der suprarostralia bij Alytes voor primitiver gehouden moet worden dan die van Rana, valt niet met zekerheid te zeggen. De waarschijnlijkheid spreekt ervoor, dat de suprarostralia in verband met het larvenleven en de ontwikkeling der hoornkaken gewijzigde deelen der trabekelhoorns zijn.

Het tweede verschilpunt ligt niet alleen in de suprarostralia zelf, maar ook in de hocrnkaken. De suprarostralia van Rana worden gescheiden aangelegd (Stöhr 1882). Ook de hoornkaken zijn hier aanvankelijk gescheiden (Héron Royer, 1889; Gaupp. 1893, 1906), hoewel Peeters (1910) dit niet bevestigen kon. De aanleg der hoornkaken bij Alytes evenwel (larve $91 / 2$ m.M., serie 13) is ongepaard.

De vertraagde aanleg der suprarostralia verklaart, waarom hun scheiding in de ontwikkeling niet meer tot uiting komt.

\section{E. PALATOQUADRATUM, CARTILAGO MECKELI, INFRAROSTRALIA.}

\section{Stadium 1.}

Het palatoquadratum is door den processus ascendens en de commissura quadrato-cranialis anterior met de trabekel kraakbeenig verbonden.

De basis der beide processus zijn breed, zoodat de vorm van een bijna gelijkbeenigen driehoek verkregen wordt, met meer of minder scherpen tophoek. Een goed ontwikkelde processus muscularis, welke zich ter hoogte van de aanhechtingsplaats der commissura quadrato-cranialis anterior verheft, is als derde uitsteeksel van het palatoquadratum te noemen.

De fenestra subocularis heeft door het nog weinig craniaal uitgegroeide palatoquadratum en de hierdoor nog dicht bijeen gelegen verbindingen met de trabekel ongeveer den vorm van een rechthoekigen driehoek aangenomen, waarvan de rechthoekszijden door trabekel en processus ascendens worden gevormd. Een membrana subocularis ontbreekt.

Er is geen verbinding van het palatoquadratum met het oorkapsel; de caudale rand valt in één vlak met den voorrand van het oorkapsel. 
Juist ventraal van de brug, die de processus ascendens en de trabekel vormen, begeeft zich de uit het ganglion proöticum ontspringende $\mathrm{R}$. ophtalmicus $\mathrm{V}$ (R.orbito-nasalis) naar de oogholte en kruist den N.II dorsaal. Mediaal van den R. opht. V loopt de R. palatinus VII. Dorsaal tegen den processus ligt het deel van het ganglion proöticum, waaruit de $\mathrm{R}$, maxillo-mandibularis $\mathrm{V}$ ontspringt. De $\mathrm{R}$. hyomandibularis VII loopt ventraal van het palatoquadratum en wijkt ter hoogte van de aanhechtingsplaats van het hyoid meer lateraal uit. Deze verbinding van palatoquadratum en hyoid is in het vlakke deel van eerstgenoemde gelegen ter hoogte van den cranialen rand van het foramen oculomotorii, derhalve op ongeveer een derde van de lengte van het quadratum, gerekend vanaf diens caudalen rand. Er is nog geen gewrichts spleet aanwezig; de verbinding geschiedt door donker gekleurd, dichtkernig weefsel.

De pars articularis quadrati is nog zeer kort. Even rostraal van den voorrand van de commissura quadrato-cranialis anterior treft men daar de gewrichtskom voor het Meckel's kraakbeen aan.

Het transversaal gelegen Meckel's kraakbeen heeft caudo-lateraal een uitsteeksel, dat om de pars articularis heen grijpt. Het kraakbeen is nog zeer jong. De R. mandibularis internus VII (chorda tympani) loopt mediaal, de R. mandibularis externus $\mathrm{V}$ lateraal van het Meckel's kraakbeen.

Ongeveer tegenover het midden van den voorrand van het Meckel's kraakbeen vindt men ter weerszijden den aanleg van twee kraakbeenstukjes, die door Peeters (1910) "paramandibularia” genoemd zijn. Ze zijn door continu weefsel met het Meckel's kraakbeen verbonden.

De infrarostralia zijn op hetzelfde jonge ontwikkelingsstadium als het Meckel's kraakbeen en zijn door een dichtkernig weefsel er mee vereenigd; zij hebben een eigen centrum van kraakbeen vorming en zijn daardoor duidelijk af te grenzen van het Meckel's kraakbeen, hoewel er nog geen gewrichtsspleet aanwezig is. In de mediaanlijn zijn beide infrarostralia caudaal door een donker gekleurd weefselstrookje verbonden, dat zich nog over enkele coupes achterwaarts voortzet. Hierin is de aanleg van een eigen- 
aardig soort verbindingsweefsel te zien, waarin later cen kraakbeenige copula zal optreden (zie stadium II).

\section{Ontwikkeling.}

Series, waarin het allereerste optreden van palatoquadratum, Meckels' kraakbeen en infrarostralia met zekerheid kon nagegaan worden, stonden me niet ten dienste. In serie 3 (larve $5 \mathrm{~m} . \mathrm{M}$.) teekent het palatoquadratum zich evenals het overige visceraalskelet onduidelijk als kernverdichting af. Duidelijk wordt de aanleg van het palatoquadratum in serie 4 (larve $5 \mathrm{~m} . \mathrm{M}$.), maar hier kan men beide verbindingen met den trabekelaanleg reeds waarnemen. Het kraakbeen van Meckel en de infrarostralia zijn hier eveneens aangelegd. Scherp teekenen zich deze en het palatoquadratum af in serie 5 (larve van 6 m.M.) als één continue, donker gekleurde weefselstrook, waaraan op horizontale doorsnede de vorm der componenten door insnoeringen zichtbaar is. In de mediaanlijn is de aanleg der infrarostralia door een eivormig toegespitst weefselstrookje verbonden, waarvan de breede basis caudaal gericht is. Een gewrichtsspleet tusschen Meckel's kraakbeen en palatoquadratum is in serie 7 (larve $6 \%$ m.M.) flauw waar te nemen. "Paramandibularia" zijn nog niet met zekerheid in aanleg aan te toonen; deze werd voor het eerst bijeen larve van 7 m.M. (serie 9) geconstateerd.

De kraakbeenvorming in het palatoquadratum geschiedt in rostrale richting. Processus ascendens en commissura quadrato-cranialis anterior, bij een larve van $7 \mathrm{~m}$.M. (serie 8) nog niet kraakbeenig, schijnen ongeveer gelijktijdig in kraakbeen over te gaan (serie 9). Het kraakbeen van Meckel en de infrarostralia hebben ieder hun eigen centrum van kraakbeenvorming.

\section{LITERATUUR.}

Stöhr (1882) vond, dat de aanleg van het Meckel's kraakbeen en de infrarostralia zich bij Rana vroeger differentieert dan die van het palatoquadratum. In zijn eerste en tweede stadium is het palatoquadratum nauwelijks te zien. Wanneer dit verschijnt, komen bijna gelijktijdig de verbindingen met de trabeculae tot stand: de commissura quadrato-cranialis ant. schijnt iets eerder aangelegd 
te worden dan de processus ascendens (Spemann, 1898). Door het ontbreken van stadia tusschen serie 3 en 4 was het eerste optreden van het palatoquadratum voor Alytes niet met zekerheid vast te stellen; toch meen ik in serie 3 reeds den eersten aanleg van het palatoquadratum waargenomen te hebben, terwijl het Meckel's kraakbeen en de infrarostralia zich nog niet afteekenen. Is deze waarneming juist, dan zou deze vertraagde aanleg wederom met het late functioneeren van den larvalen mond in verband gebracht kunnen worden.

Dat in jongsten aanleg palatoquadratum, Meckel's kraakbeen en infrarostralia één geheel vormen, werd door Stöhr (1882) en Spemann (1898) voor Rana aangetoond; evenzoo dat in den vorm hun latere afsnoering is aangegeven en er zelfstandige kraakbeencentra gevonden worden. Götte(1875) vond hetzelfde voor Bombinator.

De infrarostralia zijn bij Alytes door een donkergekleurd, kernrijk weefsel verbonden, waarin we eerst veel later een kraakbeenige copula aantreffen (zie stadium 2). Bij Rana esculenta $(6,5$ m.M.) nam Peeters (1910) reeds vroegtijdig een kraakbeenige verbinding waar; in geen enkel stadium zag hij beide helften onafhankelijk. De beteekenis van het verbindingsweefsel der infrarostralia zal bij stadium 2 nader uiteengezet worden.

De twee merkwaardige kraakbeenstukjes, die Peeters bij Alyteslarven van $43 \mathrm{~m} . \mathrm{M}$. aantrof ter weerszijden van de infrarostralia vóór het Meckel's kraakbeen, werden door hem paramandibularia genoemd (1910). Dit geschiedde in navolging van Fürbringer (1904), die bij Protopterus evenals bij Lepidosiren twee paar kraakbeenstukjes vond, die onafhankelijk van het Meckel's kraakbeen ontstaan, maar waarvan het craniale paar in den loop der ontwikkeling ermede versmelt, terwijl het caudale zijn zelfstandigheid bewaart. De blijvende isolatie der kraakbeenstukjes bij Alytes ten aanzien van het Meckel's kraakbeen doet Peeters ze met het achterste der beide paramandibularia der Dipnoi vergelijken.

Voor het eerst nam ik de paramandibularia bij Alytes met zekerheid in stadium 1 (larve $7 \mathrm{~m} . \mathrm{M}$.) waar. In tegenstelling met het Meckel's kraakbeen zijn ze nog niet kraakbeenig en slechts als kernverdichting zichtbaar. Het was niet mogelijk den al of niet zelfstandigen aanleg na te gaan, maar wel kon ik in genoemd 
stadium constateeren, dat Meckel's kraakbeen en paramandibularia reeds met elkander in aanraking zijn. Intusschen maakt de aanleg dezer kraakbeenstukjes niet den indruk van het Meckel's kraakbeen afkomstig te zijn en wijst het later kraakbeenig worden (larve $12-16^{1} / 2 \mathrm{~m}$. M.) op een zekere zelfstandigheid. In oudere series vindt men de betrekking tusschen Meckel's kraakbeen en paramandibularia steeds terug en zijn ze door een soort perichondrium verbonden Izie stadium 2). Op grond van deze betrekking tusschen beide en hun ligging zouden de paramandibularia m.i. eerder met de craniale kraakbeenstukjes van genoemde Dipnoi vergeleken kunnen worden, hoewel er van vergroeiing bij Alytes geen sprake is.

In ieder geval lijkt het mij niet aanbevelenswaardig deze kraakbeenstukjes bij Alytes paramandibularia te noemen, daar Fürbringer zelf dezen naam nog slechts onder voorbehoud aan de bewuste kraakbeentjes der genoemde Dipnoï geven wil 1 .

Een vergelijking met de onderlipkraakbeentjes der Selachii, gelijk ook Peeters aangeeft, is evengoed mogelijk. Want terecht zegt Gaupp (1906, pg. 588): „Genetische Kriterien zur Charakteristik der praekranialen Skelettheile fehlen bisher, und die diesbezüglichen Vergleiche sind noch unsicher". Wanneer men dit in het oog houdt, komt het mij niet gewenscht voor door den naam paramandibularia den indruk te wekken, alsof de homologisatie met de gelijknamige kraakbeenstukjes der Dipnoï vaststaat en schijnt het me beter voor Alytes den naam admandibularia in de plaats te stellen, waardoor tevens hun betrekking tot het kraakbeen van Meckel wordt uitgedrukt.

1) Fürbringer (1904, pag. 481) zegt hicrvan: „Sollte die Untersuchung an jüngeren Stadien eine getrennte Entsteliung (van Meckel's kraakbeen en paramandibularia), an der ich noch Zweifel hege, zeigen, so wäre dann ein besonderer Name, wie etwa Paramandibularia, zu empfehlen". 


\section{De verdere ontwikkeling van het Chondro- cranium vóór de metamorphose tor en met stadium II.}

\section{A. PLANUM BASALE, OCCIPITAALBOOG, CHORDA DORSALIS.}

Stadium II. (lengte 53 m.M., staartlengte $31.5 \mathrm{~m}$. M., achterpootlengte $3 \mathrm{~m}$. M., serie 19).

Kon in het eerste stadium van een scherpe craniale begrenzing van de basaalplaat gesproken worden, thans is dit door het sluiten van de fenestra basicranialis anterior niet meer het geval. Evenmin is dit mogelijk voor de laterale begrenzing ten aanzien van het oorkapsel. En ook caudaal is de afgrenzing niet zóó scherp, als men verwachten zou. Ter plaatse waar de occipitaalbogen zijwaarts omhoog stijgen ligt dorsaa! van de chorda een weefsel, dat craniaal aansluit bij het kraakbeen van de basaal plaat, terwijl het zich caudaal epichordaal in de wervelkolom voortzet. Het onderscheidt zich van het kraakbeen van de basaalplaat door zijn rijkdom aan dichtopeenliggende kernen met weinig intercellulaire substantie en maakt den indruk van bindweefsel, dat in kraakbeen overgaat en een product is van de skeletogenelaag om de secundaire chordascheede.

Tegenover methyleenblauw gedraagt dit weefsel, dat in oudere stadia duidelijk zijn kraakbeennatuur vertoont, zich anders dan het kraakbeen van basaalplaat of wervelbogen, daar het na Zencker fixatie en kleuring in toto geen blauwe kleur aanneemt. Om de zelfde reden en ook, omdat het in brekingsindex zeer weinig van canada-balsem verschilt, neemt men het in totalpreparaten niet waar en ziet men de caudale schedelgrens als in jongere stadia. Uit sagittale coupes blijkt, dat dit epichordaal kraakbeenachtig 
weefsel zich in de geheele wervelkolom voortzet en aan de vorming der wervellichamen deelneemt.

De basalplaat vertooní over de geheele lengte een aanzien lijke dikte. Caudaal is het bovenvlak gewelfd; ter hoogte van het for. acusticum wordt het vlakker om meer naar voren in verband met de dorso-rostraal gelegen hypophyse uitgehold te worden, waardoor een geleidelijke overgang naar den nog zeer dunnen, kraakbeenigen schedelbodem tot stand komt.

De occipitaalbogen verheffen zich ongeveer in een transversaal vlak, terwijl het proximale deel eenigszins caudaal uitgebogen is. Met dit deel van den boog articuleert later de eerste wervelboog. Distaal treedt de arcus occipitalis door de crista occipitalis lateralis met het oorkapsel in verbinding en begrenst het foramen jugulare caudaal.

De chorda is binnen den kraakbeenschedel dorsaal en ventraal door kraakbeen omgeven; alleen het deel, caudaal van het foramen jugulare gelegen, heeft ventraal geen kraakbeenbedekking. De dwarse doorsnede van de chorda, die ter hoogte van de occipitaalbogen ongeveer cirkelvormig is 1), wordt spoedig zuiver rond. Ter hoogte van het foramen perilymphaticum ext. gaat deze vorm in een verticaal-gestrekt ovaal over. Meer rostraal neemt de diameter snel af, zoodat in het vlak van het foramen perilymphaticum int. de afplatting in die mate toeneemt, dat de aanvankelijk perifeer geplaatste chordakernen nu over de geheele doorsnede dicht opeenliggen; tenslotte blijft er ook voor deze geen plaats over en is de verticale samendrukking zóó volkomen, dat de sccundaire chordascheede slechts een nauwe spleet begrenst. Even rostraal van den cranialen rand van het foramen perilymphaticum int. is de chorda verdwenen. Dorsaal gezien neemt men in totalpreparaten een vrij plotselinge toespitsing van de volumineuse chorda waar (vgl. lig. 3 en 4, Pl. II, voor een jonger stadium).

\section{Ontwikkeling.}

In stadium I vormde de rostral: rand van de basaalplaat de caudale begrenzing van de lenestra basicranialis anterior. Deze

1) Basaal is de chorda cenigszins afgeplat. 
grens gaat in den loop der ontwikkeling door de sluiting dezer fenestra, evenais de laterale grenzen ten aanzien der oorkapsels, verloren. De caudale rand is scherp begrensd en wordt door het occipitovertebraal weefsel gescheiden van den aanleg van het basale deel van den eersten wervelboog, dien men bij larven van 15 à 16 m.M. aantreft.

De occipitaalboog, die eerst in caudo-laterale richting opstijgt, krijgt door het uitgroeien der basaalplaat meer een zuiver transversalen stand.

Een crista occipitalis lateralis ontbreekt aanvankelijk en men ziet bij larven van $91 / 2$ en $12 \mathrm{~m} . \mathrm{M}$. den occipitaalboog zich direct tegen het oorkapsel aanleggen. De crista-ontwikkeling is het eerst bij larven van $16 \mathrm{~m} . \mathrm{M}$. waar te nemen en geeft op doorsnede beelden, die met overeenkomstige coupes van Rana overeenstemmen.

Een incisura occipitalis, waarin zich de basis van den eersten wervelboog schuift, is bij Alytes niet of nauwelijks ontwikkeld.

De chorda wordt dorsaa! in caudale richting overgroeid. Slechts het deel tusschen de occipitaalbogen blijft aanvankelijk onbedekt. In de uiterste chordapunt, die dorsaal is omgebogen en bijna het oppervlak van de basaalplaat ter hoogte van den cauda!en rand van het foramen acusticum bereikt, treft men nu en dan een groot aantal dooierkorrels aan, die de perifeer gelegen chordakernen van de uiterste punt afgedrukt houden. Op dwarse doorsnede vertoont deze chordapunt den cirkelvorm, terwijl de primaire chordascheede slechts met moeite of niet meer te herkennen en het lumen met dooierkorrels gevuld is. Bij een larve van $12 \% \mathrm{~m} . \mathrm{M}$. is deze uiterste punt verdwenen. De chorda eindigt ter hoogte van of even vóór den caudalen rand van het foramen acusticutin en strekt zich terminaal ongeveer even ver uit als in voorgaande stadia. Ventraal is ze hier nog niet met kraakbeen bedekt; dorsaal wel. De hoogte van de chorda neemt caudaal snel in diameter toe, tengevolge waarvan ze spoedig het oppervlak van de basaalplaat bereikt. Bij een larve van $22 \mathrm{~m} . \mathrm{M}$. strekt de chorda zich nog evenzoover uit, maar de doorsnede der punt neemt een meer driehoekigen vorm aan, wat aan een begin van samendukking mag toegeschreven worden. Deze driehoekige vorm wordt in 
oudere stadia meer en meer een verticaal gerekte ellips, terwijl het kraakbeen zich dorsaal verder naar achter over de chorda schuift. Tenslotte ontbreken in de saamgedrukte chordapunt de kernen geheel en ziet men ook ventraal ervan kraakbren optreden.

$\mathrm{Om}$ zich een volledig beeld te vormen van de wijze van reductie van de chorda, zou men de beschikking moeten hebben over een groot aantal series, daar variaties hier niet uitgesioten schijnen te zijn. Hetgeen ik bij Alytes waarnam, kan als volgt samengevat worden. De uiterste omgebogen chordapunt wordt het eerst in het kraakbeen der basaalplaat opgenomen. Hierna volgt de zijdelingsche samendrukking der punt door het uitgroeien van het lateraal gelegen kraakbeen der basaalplaat, terwijl tegelijkertijd ook de dorsale overgroeiing plaatsvindt. Ventraal geschiedt de kraakbeenontwikkeling veel langzamer. Tengevolge van de samendrukking van de chordapunt verdwijnen de levende elementen hieruit en worden tenslotte de secundaire en primaire chordascheeden in het kraakbeen der basaalplaat opgenomen. Aldus vindt een "terugdringen" der chordapunt plaats.

\section{LITERATUULR.}

Belangrijke verschillen treft men in het caudale schedeldeel vóór de metamorphose bij Rana, Bombinator en Alytes niet aan.

De crista occipitalis lateralis ontwikkelt zich bij Alytes tenslotte evenzeer als bij Rana; door de vroegtijdige versmelting van occipitaalboog en oorkapselwand is niet meer na te gaan of deze crista van het oorkapsel of van den boog zelf afkomstig is.

Naar de beschrijving van Gaupp (1893) te oordeelen, ontwikkelt de crista occipitalis lateralis zich bij Rana fusca-larven tusschen 14 en 29 m.M. als een kraakbeenlijst, die ter halver hoogte van het oorkapsel ontspringt en de ruimte tusschen occipitaalboog en oorkapsel overbrugt. Bij Rana legt zich dus de occipitaalboog aanvankelijk niet zooals bij Alytes direct tegen het oorkapsel aan. Dit verschil wordt door de vroegtijdige ontwikkeling van den occipitaalboog bij laatstgenoemde voldoende verklaard (vgl. pag. 44). Ook bij Alytes krijgt men in doorsneden den indruk, dat de cristavorming op een verdikking van den oorkapselwand berust. 
Op het nagenoeg ontbreken van een incisura occipitalis bij Alytes werd reeds door Peeters (1910) gewezen.

De reductie van de chorda vindt op overeenkomstige wijze plaats als bij Bombinator en Rana. Door Goette (1875) en Gaupp (1893) werd een reductie in drie gedeelten beschreven: le het voorste deel, dat zijdelings gecomprimeerd wordt, 2e een middendeel, dat verkraakbeent, $3 e$ een dee!, dat ventraal buiten de basaalplaat verdrongen wordt; deze beide laatste reductieprocessen vallen tijdens en na de metamorphose en kunnen dus hier buiten beschouwing blijven ${ }^{1}$. De beschrijving van de reductie $\in$ n samenvouwing van het eerste chordadeel door genoemde auteurs geldt ook voor Alytes.

Omtrent de kraakbeenige overgroeiing van de chorda geeft Peeters (1910) voor een Älytes-larve van $45 \mathrm{~m} . \mathrm{M}$. een variatie aan, daar de chorda hier ventraal met kraakbeen bedekt wordt. Ook bij enkele Rana fusca-larven vond Peeters hetzelfde. In mijn series kwam een dergelijke overgroeiingswijze niet voor.

\section{B. CAPSULA AUDITIVA, TECTUM POSTERIUS.}

\section{Stadium II.}

Bij de beschrijving van het oorkapsel c. a. mogen alleen die punten naar voren gebracht worden, waarin Alytes verschillen vertoont met Rana fusca. Het ontbrekende vindt zijn aanvulling in de schildering, die Gaupp (1893. pag 307 seq.) van Rana in het tweede stadium geeft.

Het gehoororgaan is thans geheel door een solide kraakbeenhulsel omgeven en door een medialen wand van het cavum cranii afgęgrensd. De canales semicirculares zijn rondom in kraakbeen ingesloten. Het ovale venster heeft zijn laterale ligging en elliptischen vorm aangenomen; het operculum dekt het caudale deel van de opening; de pars interna plectri vertoont reeds kraakbeenvorming.

Van de verschillende door Gaupp genoemde foramina ontbreekt het foramen perilymphaticum accessorium "). De foramina perilym-

1) Reeds hier kan gezegd worden, dat Alytes ook in dit opzicht met Rana overeenstemt.

2) Ook in andere series trof ik dit bij Alytes niet aan. 
phatica superius en inferius (internum en externum, Peeters) zijn op overeeni mstige wijze als bij Rana georiënteerd. Het foramen acusticum heeft zich in een for. acusticum anterius en posterius gedeeld.

De nervus facialis treedt met de gehoorzenuw het oorkapsel binnen en wordt hier in een kanaal ingesloten. Daar dit intracapsulaire verloop van den nervus facialis voor Anuren tot op heden onvoldoende bekend is 1), moge een meer uitvoerige beschrijving aan de hand van de half schematische figuur 16, Pl. III hieronder volgen.

De nervus octavus heeft bij Alytes als gewoonlijk een ramus posterior en anterior. Tegelijk met den N. VIII ontspringen een clorsale en ventrale wortel van den N. VII, die, nadat de caudale tak van den $N$. VIII zich afgesplitst heeft, gezamenlijk met den R. anterior VIII rostraal verloopen (fig. 16 a, b en c).

Ter hoogte vari den oorsprong van den $\mathrm{N}$. V wordt de dorsale wortel van den N. VII zelfstandig en vervolgt zijn weg binnen de schedelholte (fig. 16 c en d). De ramus anterior VIII blijft met den ventralen wortel van den N. VII vereenigd, terwijl de mediale ligging van laatstgenoemde zenuw door kerngroepeering duidelijk aan het licht komt. Beide betreden door het for. acusticum anterius, dat juist voor en ventraal van het for. pro ductu endolymphatico gelegen is, de oorkapselruimte (fig. $16 \mathrm{~d}$ ).

Het wandje, dat het for. acusticum post. en ant. scheidt, ligt niet in het zelfde vlak als de mediale oorkapselwand, maar rijst uit een meer naar binnen gelegen deel van den oorkapselbodem op. In een doorsnede ter hoogte van het for. acusticum post. ziet men het punt $x$, waar zich de rostrale rand van het for. acusticum ant., de oorspronkelijke mediale oorkapselwand, wederom zal verheffen en het punt $y$, het raakpunt van den nieuw gevormden scheidingswand tusschen for. acusticum post. en ant. en den oorkapselbodem (fig. 16 b, c en e).

De dorsale rand van het for. acusticum ant. is sterk verbreed, daar zij niet zuiver verticaal geplaatst is, maar binnenwaarts in de holte van het oorkapsel is omgebogen, waardoor een grooter

1) Gaupp (1911) spreekt terloops over een facialiskanaal bij Bombinator en Alytes. 
begrenzingsvlak wordt verkregen (fig. $16 \mathrm{~d}$ ). Na de rostrale sluiting van het for. acusticum ant. zet zich deze breede rand binnen het kapsel in orale richting als een lijst voort, ventraal waarvan de ramus ant. VIII met den ventralen wortel van den N. VII verloopen (fig. 16 c). Eerstgenoemde zenuw splitst zich spoedig af en begeeft zich naar de inwendige deelen van het gehoororgaan.

De $N$. facialis wordt nu in een kanaal ingesloten, doordat genoemde lijst zich in het veriengde van het punt y met den oorkapselbodem verbindt (fig. 16 f). De wand van dit kanaal is derhalve uit volgende elementen opgebouwd: le een horizontaal deel, afkomstig van den ventralen oorkapselwand en de basaalplaat, 2 e cen verticaal deel, afkomstig van den medialen oorkapselwand, 3e een schuinsch wandje, in ligging overeenkomend met den scheidingswand van het foramen acusticum post. en ant. Dit schuinsche wandje neemt naar voren in dikte toe, terwijl de zenuw meer ventraal ombuigt en gaat in den oorkapselwand zelf over. De horizontale wand daarentegen verdwijnt langzamerhand, waardoor de zenuw buiten het oorkapsel vrij komt te liggen en gelegenheid verkrijgt om zich, nadat de cupula ant. zich van de basaalplaat verwijderd heeft, met het ganglion $V$ te vereenigen (fig. $16 \mathrm{~g}$ en $\mathrm{h}$ ).

Men moet derhalve onderscheid maken tusschen den verticalen, medialen oorkapselwand, die ook het foramen perilymphaticum sup. (int.) en het primaire ongedeelde foramen acusticum omgrenst, en het wandje, dat laatstgenoemde in twee foramina deelt en zich voortzet in den wand, die den N. VII van den $N$. VIII en het cavum capsulae auditivae scheidt.

Ten aanzien van den verticalen wand loopt de N. VII (ventrale wortel) lateraal, in tegenstelling met Rana, waar deze zenuw mediaal ligt. Schijnbaar betreedt de N. VII in dit stadium de oorkapselruimten niet, maar bij de ontwikkelingsgeschiedenis zal blijken, dat dit wel degelijk het geval is.

Het tectum posterius verbindt beide oorkapsels en bezit geen taenia tecti medialis, zooals bij Rana. In geen enkel stadium, ook niet in de metamorphose, wordt deze bij Alyies aangetroffen. Evenmin kan men bij Alytes van zelfstandige taeniae tecti marginales spreken. Wel treft men medio-dorsaal aan de oorkapsels lijsten aan, dip een voortzetting zijn van het tectum posterius en 
als kraakbeenige onderlaag voor de parietalia, die in dit stadium reeds aanwezig zijn, dienen. Men zou deze lijsten hier beter cristae marginales kunnen noemen, daar uit de ontwikkelinsgeschiedenis blijken zal, dat ze bij Alytes nooit zelfstandigheid bezitten.

De crista parotica is aan de linkerzijde als een rostro-laterale verdikking van den oorkapselwand zichtbaar; rechts is dit minder duikelijk. Een verbinding tusschen het oorkapsel, i.c. de crista parotica, en het palatoquadratum door een processus oticus ontbreekt (zie palatoquadratum).

\section{Ontwikkeling.}

Het oorkapsel, dat in het eerste stadium (7 m.M.) nog slechts onvolkomen ontwikkeld was (fig. 1 en 2, Pl. I), wordt zeer snel aan alle zijden met kraakbeen omkleed. Reeds bij een larve van $12^{1}, 2 \mathrm{~m} . \mathrm{M}$. is het kapsel rondom gesloten en ook de mediale wand aangelegd. Op de wijze, waarop deze sluiting plaats vindt, kan hier slechts oppervlakkig ingegaan worden, daar de benoodigde series (tusschen $91 / 2$ en $12^{1 / 2}$ m.M.) ontbraken.

Het kraakbeen van de cupula ant. en post. groeit tot vorming van het dorsale dak beiderzijds naar elkander toe, spoedig aansluitend bij het kraakbeen, dat zich van den canalis semicircularis lat. af dorso-mediaal uitbreidt.

Van den medialen wand gaat het deel, tusschen het for. N. VIII en het for. perilymphaticum int. gelegen, het eerst in kraakbeen over, weldra gevolgd door de deelen, die aan de cupula ant. en post. grenzen. Er blijft aanvankelijk één groote opening, die het for. acusticum en het for. pro ductu endolymphatico omvat.

Van de canales semicirculares wordt de canalis semicircularis lat. het eerst, beginnend bij de cupula ant., in caudale richting omgroeid; hetzellde geldt voor den canalis semicircularis ant. terwijl de canalis semicircularis post. het laatst volgt.

De foramina perilymphatica superius (internum) en inferius (externum) zijn bij een larve van $22 \mathrm{~m} . \mathrm{M}$. voor het eerst kraakbeenig omgrensd.

De ontwikkeling der perilymphatische ruimten ${ }^{1}$ ) treft men bij

1) Voor de hieronder gebezigde terminologie vergelijke men Harrison (1902). 
een larve van 16 m.M. (serie 15) aan en tegelijk ook den aanleg van het wandje, dat het for. perilymphaticum sup. (int.) caudaal zal begrenzen. Men ziet hier in samenhang optreden: den recessuspartis neglectae, den ductus perilymphaticus en het spatium meningeale en afgescheiden van deze ruimten : den recessus partis basilaris met den saccus perilymphaticus. Tusschen spatium meningeale en saccus perilymphaticus is nog geen communicatie. De recessus partis basilaris binnen het oorkapsel gelegen en het spatium meningeale in de schedelholte raken elkander en het is in dit raakvlak, dat zich het nieuwe wandje vormen gaat (fig. 19 a, Pl. III). Dit wandje ligt in hetzelfde vlak als de mediale oorkapselwand en sluit bij het reeds vroeger ontwikkelde kraakbeen van laatstgenoemden wand, caudaal van het for. acusticum, aan. Wanneer het bij een larve van $22 \mathrm{~m}$.M. in kraakbeen is overgegaan (fig. 20 a, Pl. III), kan men dus voor het eerst van een foramen perilymphaticum sup. (int.) spreken. Dit is derhalve een opening in den medialen oorkapselwand, die eerst na den aanleg van den ductus perilymphaticus ook caudaal kraakbeenig begrensd wordt.

$\mathrm{Bij}$ de vroeger genoemde larve van $16 \mathrm{~m}$.M. ziet men ook hoe het for. perilymphaticum inf. (ext.) tot stand komt. Fig. 19 b, Pl. III, stelt een doorsnede dezer larve voor, meer caudaal dan die van fig. 19 a getroffen. Het oorkapsel heeft zich van de basaalplaat verwijderd en vertoont een medio-ventrale externe opening, waarin de saccus perilymphaticus nog voor een deel gelegen is. Dit is het for. perilymphaticum inf. (ext.), hetgeen als zoodanig bij een larve van 22 m.M. eerst recht duidelijk wordt. Het vroeger genoemde begrenzingswandje van het for. perilymphaticum sup. is hier in kraakbeen overgegaan (fig. $20 \mathrm{~b}, \mathrm{Pl}$. III) en heeft het oorkapsel caudaal over een grooteren afstand met de basaalplaat verbonden. Men kan dit wandje achterwaarts tot het punt, waar saccus perilymphaticus en spatium meningeale met elkander door den ductus reuniens samenhangen, d.w.z. tot het for. jugulare, vervolgen. Het for. perilymphaticum inf. (ext.) is dus een deel van den oorkapselwand, dat waarschijnlijk onder invloed van den sterk ontwikkelden recessus partis basilaris en den saccus perilymphaticus niet kraakbeenig wordt en van den aanvang extern gelegen is. 
Het foramen acusticum is aanvankelijk éen met het for. pro ductu endolymphatico. Bij een larve van $15 \mathrm{~m} . \mathrm{M}$. treft men dezen toestand nog aan; bij een larve van $22 \mathrm{~m}$.M. heeft de scheiding tusschen beide zich door een horizontalen kraakbeenwand voltrokken.

De vorming van het gedeeld for. acusticum voor den ramus post. en ant. N. VIII moet plaats vinden bij larven tusschen 29 en 53 m.M.

Het foramen N. VII vindt men reeds in den oorkapselwand bij een larve van $91 / 2 \mathrm{~m} . \mathrm{M}$. Het is hier zeer duidelijk waar te nemen, dat de facialis zich met den ramus ant. N. VIII binnen het oorkapsel begeeft en lateraal gelegen is van den medialen wand, die in dit stadium nog vliezig is en de zenuw van den oorsprong van den N. V. scheidt. De medio-ventrale vliezige oorkapselwand wordt door den N. VII doorboord, hetgeen ook in een larve van $12 \frac{1}{2}$ m.M. kan waargenomen worden, waar het foramen juist ter plaatse, waar basaalplaat en oorkapsel elkander raken, aangetroffen wordt. Bij een larve van 16 m.M. is de toestand eenigszins veranderd, doordat de ontwikkeling van den medialen wand zooveel verder is voortgeschreden en nu het for. acusticum ook rostraal kraakbeenig begrensd wordt. Deze kraakbeenwand scheidt den oorsprong van den N. V van den N. VII. Aanvankelijk loopt de N. facialis lateraal van dezen wand, doch op de plaats waar de cupula ant. zich van de basaalplaat verwijdert en de $\mathrm{N}$. facialis het oorkapsel door het foramen verlaten heeft, wordt deze zenuw door drie wanden omgrensd: de basaalplaat, den medialen en den ventralen oorkapselwand (fig. 18, Pl. III). Dit stadium vormt het uitgangspunt van de latere kanalvorming, waarvan liet begin bij een larve van $25 \mathrm{~m}$.M. te zien is. Het orale en kleinste deel van dit kanaal komt tot stand door de uityroeiing van de basaalplaat in rostrale en laterale richting, wardocr de zenuw over een korten afstand tusschen de basaalplaat en het oorkapsei doorloopt. Men verkrijgt dezen toestand door in fig. 20, Pl. III, de wanden volgens de stippellijnen verbonden te denken. De lengte van dit extracapsulaire kanaalgedeelte echter is en blijft ook later zeer kort. Het grootste aandeel aan de kanaalvorming wordt door 
het kraakbeenig omgroeien binnen het oorkapsel zelf teweeg gebracht. Hetgeen in fig. $16 \mathrm{f}$ is afgebeeld, is dan ook niet het moment, waarop de zenuw tusschen oorkapsel en basaalplaat gelegen is, maar geeft een beeld van de omgroeiing binnen het oor kapsel. Een vergelijking tusschen serie 17 en 19 kan dit duidelijk maken. Fig. 17a, P1. III, stelt een dwarse doorsnede uit serie 17 (larve 25 m.M.) voor, ongeveer terzelfder hoogte genomen als die van fig. $16 \mathrm{f}$. Bij deze larve van $25 \mathrm{~m}$.M. ligt de zenuw vrij binnen het oorkapsel en is van een omgroeiing nog geen sprake. In fig. $17 \mathrm{~b}$ (overeenkomend met fig. $16 \mathrm{f}$.), is de ligging van den oorspronkelijken oorkapselwand gestippeld geteekend en blijkt dus, dat de zenuw inderdaad nog binnen het oorkapsel ligt, hoe wel door den nieuw gevormden kraakbeenwand van de oorkapselruimte gescheiden. Naarmate het oorkapsel in grootte toeneemt, wordt het kanaal in caudale richting verlengd, zoodat in serie 21 (larve $55 \mathrm{~m} . \mathrm{M}$.) de N. VII bijna terstond in een eigen kanaal besloten wordt, waaraan door de kraakbeenstructuur zeer duidelijk het feit der dorsale overgroeiing te zien is.

Ulit het bovenstaande volgt, dat het punt $y$ in fig. 16 een punt is binnen het oorkapsel gelegen en derhalve het scheidingswandje tusschen de beide foramin acustica een bizonder karakter heeft en met recht van den medialen, zich eerst ontwikkelenden oorkapselwand onderscheiden werd.

Samenvattend kan men dus zeggen, dat de N. facialis den oorkapselwand primair doorboort, en secundair in een kanal gesloten wordt, waarvan een zeer klein rostraal deel door oorkapsel en basalplaat gevormd wordt, terwijl het grootste en voornamste deel door omgroeing binnen het oorkapsel ontstaat.

De sluiting van de fenestra ovalis, die in het eerste stadium nog zeer wijd en onregelmatig gevormd is, vindt in rostro-caudale en medio-laterale richting plaats.

Bij een larve van $12 \frac{1}{2} \mathrm{~m} . \mathrm{M}$. is de dorsale begrenzing scherp aangegeven door het kraakbeen, dat den canalis semicircularis lat. bekleedt. Het ovale venster strekt zich hier uit van de pars basilaris en lagena, welke eerst kort zijn aangelegd, tot terhoogte van den ductus endolymphaticus. De medio-ventrale begrenzing is 
nog niet scherp, daar het kraakbeen zich zonder duidelijken overgang in de kernrijke membraan, die de opening bedekt, voortzet. - Bij een larve van 16 m.M. heeft liet venster zijn ovalen vorm aangenomen en is het aan alle zijden kraakbeenig scherp begrensd. De grootte neemt bij het uitgroeien der larven in verhouding toe.

Men vindt het begin van ontwikkeling van het tectum posterius bij een larve van 12\%.2 m.M., waar de laterale deelen, grenzend aan het oorkapsel en juist caudaal van den ductus endolymphaticus gelegen, kraakbeenig zijn. Het middendeel is nog niet in kraakbeen overgegaan en bestaat uit prochondraal weefsel met langgerekte kernen. Het laterale kraakbeen zet zich voort in het kraakbeendak van den sinus superior.

Een larve van $16 \mathrm{~m} . \mathrm{M}$. vertoont de eigenaardigheid (wat meerdere malen geconstateerd kon worden), dat de eene zijde de andere op sommige punten in ontwikkeling vooruit is, $W_{i j}$ zien hier links het nu kraakbeenige middenstuk van het tectum posterius met het laterale kraakbeen samenhangen, terwijl rechts tusschen beide een vliezige zône aanwezig is. Dit wijst zeer waarschijnlijk op een zelfstandig optredend middengedeelte, dat secundair met de zijstukken versmelt. Direct waargenomen werd dit door het onbreken van een daarvoor geschikte serie niet. Bij cen larve van $22 \mathrm{~m} . \mathrm{M}$. is het tectum posterius geheel kraakbeenig.

Een taenia tecti medialis is in geen enkel stadium aan te treffen.

De cristae marginales ontwikkelen zich in aansluiting bij de laterale deelen van het tectum posterius in rostrale en mediale richting en zetten zich voort in den schedelzijward. In geen stadium zijn ze, als bij Rana, vrij van het corkapsel en men kan hen derhalve den naam van taeniae niet geven.

\section{LITERATUUR.}

Gaupp (1893) heeit ioc. Rand vitwe(1) de wijac, waarop het oorkapsel door lisakbeen omgeren wocit, bechreven. Recds vroeger werd er ep gewezcn, hait bij Alytes nict zcoals bij Rana als uitgangspunten het mesotisch kraakbeen on het kraakbeen om 
het lateraal kanaal, het periotische kraakbeen, genomen mag worden. De kraakbeenvorming bij Rana fusca gaat echter niet regelmatig vanaf deze beide punten voort, maar men ziet volgens Gaupp bepaalde centra optreden, zooals bijv. de lijst, die aan de medio-dorsale zijde van het labyrinth beide cupulae verbindt. Hieruit ontstaat het dak en een deel van den medialen wand. Peeters (1910) daarentegen zag het dak van den canalis ant., sinus superior en canalis post. het laatst kraakbeenig worden. Van het lateraal kanaal groeit het kraakbeen mediaalwaarts over het dak tot de laterale rand van den canalis ant. en post. bereikt wordt en vormt een lijst; evenzoo wordt ook aan de mediale zijde van den sinus superior en den canalis ant. en post. een lijst gevormd. Van uit deze lijsten gaan de sinus en later de boogkanalen in kraakbeen over. Deze beschrijving van Peeters voor Rana fusca geldt, vour zoover nagegaan kon worden, ook voor Alytes.

Bij Rana, Alytes en andere Anuren, ook Pipa en Xenopus, worden de drie boogkanalen door kraakbeen rondom omsloten. Bij Ürodelen daarentegen geschiedt dit met den canalis post. meestal niet en wordt er in dat geval geen septum posterius aangelegd (Okajima 1911 a) $\left.{ }^{1}\right)$.

Necturus (Peeters, 1910), Hynobius en Onychodactylus (Okajima, 1911a. vormen ii dit opzicht uitzonderingen, hoewel bij de t:ver laatstgrnoemden het vosikomen van een septum posterius schijnt te varieeren $\because$. Daar bij de ontwikkeling van het vliezig gehoororgaan de achterste booggang het laatst tot stand komt, is het begrijp:lijk. dat cleze ook het laatst kraakbeenig omsloten zal worden (Okajima, 1912). De toestand bij Anuren, waar het septum post. nà het septum ant. en lat. gevormd wordt, is hiermede in overeenstemning. Het septum post. is val de drie, mede in verband met hetgeen voor sommige Urodelen geldt, blijkbaar het phylogenetisch jongste. Onder de lagere Craniota vindt men bij Cyclostomen en Lophobranchii geen kraakbeen-

1) Peeters (1910) vond bij Triton slechts het septum anterius ontwikkeld. in tegenstelling met Gaupp (1906), die ook het septum laterale aantrof.

2) Ook Ichthyophis (Peter, 1898) onder de Gymnophionen bezit drie septa. 
kanalen, bij de Ganoiden slechts twee (geen can. ant.). Elasmobranchii en Dipnoi hebben evenals Sauropsida en Zoogdieren steeds drie kanalen.

Het voorkomen van één foramen perilymphaticum heeft langen tijd als typisch voor Utodelen gegolden. Intusschen is dit sedert het onderzoek van Okajima (1911 b en 1912) voor deze groep niet geheel juist gebleken. Bij Hynobius komt larvaal slechts één opening vóór in den medialen oorkapselwand; later echter treft men hier twee foramina aan, achter elkaar gelegen (for. perilymphaticum ant. en post.). Door de ontwikkeling van de pars basilaris wordt de recessus partis basilaris van den ductus perilymphaticus afgedrongen. Een bindweefselstreng tusschen dezen recessus en den ductus in het foramen uitgespannen deelt het secundair in de twee genoemde openingen. De bindweefselstreng gaat direct in been over. Deze vormingswijze van het for. perilymphaticum ant. en post. moet men scherp scheiden van de vorming der beide foramina perilymphatica der Anuren. Hier bij Hynobius heeft men met een secundair gedeeld foramen te doen, dat ongedeeld met het for. perilymphaticum sup. (int.) der Anuren vergeleken mag worden.

De vorming van het for. perilymphaticum inf. (ext.) der Anuren hangt ten nauwste samen met de sterke ontwikkeling van de pars basilaris en de lagena in deze groep en den hoogen ontwikkelingstrap, waarop het perilymphatische stelsel hier staat. Harrison (1902), die een speciale studie van de ontwikkeling van het perilymphatisch systeem bij Amphibia gemaakt heeft, meent, dat dit foramen bij Anuren voor het eerst gevormd en onder invloed van den recessus partis basilaris onafhankelijk van het for. perilymphaticum sup. (int.) ontstaan is.

De ontwikkelingsgeschiedenis bij Alytes deed zien, dat men beide openingen zeker niet als een gedeeld ",foramen rotundum" (Hasse, 1872) moet opvatten. Ook Peeters (1910) beschouwt beide foramina bij Rana als gepraeformeerd.

Ten gunste van de hypothese van Harrison kan ook het volgende dienen. De meening, dat bij alle Anuren tu'ce for. perilymphatica zouden voorkomen is mij niet juist gebleken. Wel geldt dit voor volwassen Anura Phaneroglossa (larvaal is er somtijds slechts éen 
opening: Bufo, volgens Harrison), maar niet voor Pipa americana'), waar men alleen het for. perilymphaticum int. vindt. Het perilymphatisch stelsel bij dezen vorm is zeer weinig gespecialiseerd, nog minder dan bij Urodelen. Een recessus partis basilaris, dien men bij Triton, Salamandra (Harrison) en Hynobius (Okajima) hoewel slechts als een kleine uitstulping van den ductus perilymphaticus steeds aantreft, ontbreekt hier ten eenemale \%). De pars basilaris legt zich direct tegen den ductus perilymphaticus aan. Door het for. perilymphaticum int., in den medialen oorkapselwand gelegen, betreedt de ductus perilymphaticus de schedelruimte, buigt caudaal om en eindigt blind in een spatium meningeale, dat ziet tot het foramen jugulare uitstrekt.

In 't algemeen kan men zeggen, dat wanneer de recessus partis basilaris niet (Pipa) of weinig (Urodelen; Hynobius, larvaal) ontwikkeld is, en binnen het oorkapsel ligt, men slechts één for. perilymphaticum vindt, gelegen in den medialen oorkapselwand. Dit is blijkbaar het phylogenetisch oudere foramen.

Bij de Anura Phaneroglossa met hun sterk ontwikkelden recessus partis basilaris treedt voor het eerst het for. perilymphaticum inf. (ext.) op. Na hetgeen omtrent de ontwikkeling en de ligging der beide for. perilymphatica gezegd is, zal het ook duidelijk zijn, dat de door Peeters (1910) voorgestelde benamingen: for. perilymphaticum internum en externum de voorkeur verdienen boven de door Gaupp gebruikte (superius, resp. inferius).

Of er bij Rana inderdaad een for. perilymphaticum accessorium wordt aangetroffen is niet geheel zeker. Behalve Gaupp maakt ook Harrison (1902) er melding van, doch Peeters (1910)' trof het in geen enkel stadium aan. Daar het kraakbeenwandje, dat bij Rana het for. perilymphaticum accessorium van het for. jugulare scheidt, slechts kortstondig bestaat, kan het zijn, dat het door deze oorzaak Peeters ontgaan is, terwijl het evenmin is uitgesloten,

1) De Xenopus-larve was, wat het gehoororgaan betreft niet voldoende geconserveerd om met zekerheid den bouw van het perilymphatisch systeem na te gaan.

2) Dit geldt voor larven in de metamorphose, lich. lengte 11,5 m.M., staartlengte 12,5 m.M. Het kan zijn, dat in het volwassen dier zich alsnog een kleine recessus ontwikkelt. 
dat de vorming even als die van het scheidingswandje tusschen for. acusticum ant. en post. somtijds achterwege kan blijven.

Dat er bij sommige Anuren, als Alytes en Bombinator ${ }^{1}$ ), een facialiskanaal aanwezig is, wordt door Gaupp (1911) terloops vermeld, zonder dat hij echter eenige aanwijzing omtrent de ontwikkeling geeft. Toen hij vroeger (1893) een verklaring trachtte te geven van het verschillend facialisverloop bij Urodelen en Anuren, was hem het bovenstaande blijkbaar nog niet bekend. Als gemeenschappelijk uitgangspunt nam Gaupp het facialisverloop bij Siredon, Necturus en Amphiuma aan, waarvan hij eenerzijds den toestand bij Triton, anderzijds dien van Rana afleidde. Bij Siredon e.a. betreedt volgens hem de facialis slechts in schijn de oorkapselruimte; inderdaad verloopt ze door een ventraal van de cupula anterior gelegen kraakbeenkanaal, waarvan het dak door deze cupula en de bodem door de basaalplaat gevormd wordt. Denkt men zich het dak weg, dan krijgt men den toestand, zooals die bij Triton voorkomt ${ }^{2}$ ); verdwijnt de bodem en dus de verbinding van basaalplaat en oorkapsel, dan heeft men het geval van Rana en andere Anuren.

De ontwikkeling van het kanaal bij Alytes doet aan deze opvatting twijfelen, daar hier gebleken is, dat het groote verschilpunt met Rana niet in de eerste plaats in de kanaalvorming gelegen is, maar in het feit, dat de N. facialis inderdaad de oorkapselruimte betreedt en lateraal van den medialen oorkapselwand loopt, terwijl bij laatstgenoemde en de meeste Anuren het mediale verloop het gewone is. Tevens geeft Alytes een voorbeeld, hoe men uit de latere isolatie van den N. VII in het kraakbeenkanaal van de oorkapselruimte de verkeerde gevolgtrekking zou kunnen maken, dat de N. VII het oorkapsel niet betreedt en tusschen oorkapsel en basaalplaat gelegen is.

Uit latere onderzoekingen van Peeters (1910) is gebleken, dat er bij Siredon en Necturus van een kanaalvorming geen sprake

1) Pipa en Xenopus hebben geen foramen N. VII of facialiskanaal.

2) Voor Necturus en Triton is door Miss Platt en Pceters in tegenstelling met de waarneming van Gaupp aangetoond, dat de $N$. facialis wel degelijk de oorkapselrulmte betreedt. 
is en bij Triton een kanaal tot stand komt door het uitgroeien van een naar binnen uitspringende lijst van den medialen oorkapselwand. „Deze (lijst) is door een dunne, niet kraakbeenige plaat (van been?) verbonden met den lateralen rand, welke hooger gelegen is dan de mediale, van de opening voor den ramus hyomandibularis" (pg. 41). De onhoudbaarheid der theorie van Gaupp is door Peeters voor Uirodelen afdoende aangetoond.

Het verloop van den N. VII bij Alytes binnen het corkapsel en lateraal van den medialen oorkapselwand en het secundair in een kanaal besloten worden, hetgeen tot op zekere hoogte met de kanaalvorming bij Triton overeenkomst vertoont, doet Alytes en waarschijnlijk ook Bombinator ${ }^{1)}$ een aparte plaats innemen onder de tot nu toe onderzochte Ānuren en mag in verband met den toestand bij Urodelen als primitief beschouwd worden. Onder Visschen, Reptielen, Vogels en Zoogdieren vindt men dikwijls speciale openingen voor den N. VII en in sommige gevallen lenkele Selachii, Vogels en Zoogdieren) een facialiskanaal (een overzicht geeft Gaupp, 1911), doch steeds heeft men hier met een extracapsulair verloop van den $\mathrm{N}$. facialis te doen.

Alleen bij Petromyzon betreedt de facialis met den acusticus het oorkapsel en verlaat eerstgenoemde dit door een foramen in den bodem (Ketel 1873; 2).

De sluiting van het primaire ovale venster tot het secundaire heeft bij Alytes op overeenkomstige wijze plaats als bij Rana (Gaupp, 1893). Ook hier vindt men een verkleining van de opening in cranio-caudalé richting. De caucale grens blijft nagenoeg constant. Eveneens wordt de opening door het lateraal uitgroeien van het kraakbeen in den ventralen oorkapselwand verkleind.

Omtrent den oorsprong van tectum posterius (synoticum) zijn de meeningen der auteurs verdeeld. Er zijn er, die aannemen, dat het tot den occipitaalboog gerekend moet worden, terwijl anderen

1) Götte (1875) vermeldt cen dergelijk facialis-verloop voor Bombinator niet: evenmin blijkt dit uit zijn afbeeldingen.

2) Gaupp (1906) nocmt onder degenen, die het binnentreden van den facialis in het ourkapsel voo: Cyclostomen beschrijven: Schneider (1879), Wiedersheim (1880), Hatschek (1892), doch nieł Ketel, die het reeds zes jaren vóór Schneider vermeldt. 
het een zekere zelfstandigheid toekennen of afleiden van het oorkapsel. Parker en Götte zijn de eerste meening toegedaan; Wiedersheim en Stöhr komen voor Urodelen tot de laatste con clusie. Ook in de nieuwere literatuur blijft deze tegenstelling bestaan.

Voor Anuren vindt men alleen opgaven omtrent Rana bij Gaupp en Peeters.

Gaupp (1893) zag den aanleg van het tectum posterius, dat bij een larve van $21 \mathrm{~m} . \mathrm{M}$. reeds geheel ontwikkeld was, bij een larve van $16 \mathrm{~m} . \mathrm{M}$. lengte en nam waar, dat cen onafhankelijk middenstuk, door fibreus bindweefsel met de randlijsten van het oorkapsel verbonden, het eerst gevormd werd. Volgens hem ontstaat het tectum posterius niet door het naar elkaar toegroeien dezer randlijsten met als gevolg haar mediane versmelting, maar door zelfstandige kraakbeenvorming in het schedeldak. Bij een Triton-larve van $12 \mathrm{~m} . \mathrm{M}$. vond hij een analoge vorming.

Peeters (1910) is het met deze opvatting niet eens. Nooit zag hij bij Rana een zelfstandigen aanleg van het tectum posterius. In verband met Triton rekent hij het dar ook tot den occipitaalboog, die eerst met het oorkapsel in verbinding treedt, als dit voor een deel in kraakbeen is overgegaan. Het kan dus bij Rana den indruk wekken, alsof het tectum posterius van uit het oorkapsel uitgroeit, terwijl het inderdaad tot den occipitaalboog behoort.

Bij Urodelen spreken de feiten over het algemeen tengunste van de opvatting, dat het tectum tot den occipitaalboog gerekend mag worden. Miss Platt (1897) zag bij Necturus twee kraakbeenstukjes onafhankelijk optreten 1), die door haar vergeleken werden met de kraakbeenstukjes, die de dorsale uiteinden der neuraalbogen verbinden. De occipitaalboog verbindt zich eerst met het oorkapsel, daarna met let tectum interoccipitale ").

1) Door Winslow (1898) werd dit niet gevonden en door Peeters (1910) betwijfeld.

2) Op voorstel van Gaupp werd de naam tectum synoticum door haar in tectum interoccipitale gewijzigd, hoewel Guupp zelf (1906) de genetische cenheid van tectum en occipitaalboog niet voor bewezen houdt, 
Winslow (1898), die het tectum evenzeer als een voortzetting van den occipitaalboog beschouwt, zag echter bij Urodelen, noch bij Anuren hierin afzonderlijk kraakbeen optreden, hetgeen waarschijnlijk door gebrek aan desbetreffende stadia verklaard moet worden. Peeters (1910) onderzocht Triton en Necturus in dit opzicht. Bij Triton kon hij de vorming van het tectum posterius zelf niet nagaan, doch uit enkele totaalpreparaten meent hij te mogen concludeeren, dat het tectum niet zelfstandig ontstaat, maar in aansluiting bij den occipitaalboog, die zich lateraal en rostraalwaarts over den oorkapselwand voortzet, tot waar later het tectum gevormd wordt. Bij Necturus is het tectum een voortzetting van den nccipitaalboog, die zich rostraal en mediaal ombuigt en zich met het oorkapsel vereenigt.

Peeters rekent dan ook het tectum posterius tot den occipitaalboog. Het voornaamste bewijs hiervoor zoekt hij in den definitieven vorm van het tectum, dat een voortzetting van den orcipitaalboog en de crista occipitalis lateralis is, en in de wijze van verbeening, die sterk herinnert aan die van een echten wervelboog. Een verschilpunt tusschen de sluiting van den zgn. occipitaalboog en van een wervelboog blijft echter, zooals Peeters e.a. opmerkten, hierin bestaan, dat de mediale verbinding bij den eersten rostraad en bij den tweeden caudaad gericht is.

Gaupp (1906) stelde, zoolang de herkomst van het tectum niet vaststaat, den neutralen naam tectum posterius voor inplaats van tectum synoticum, daar in dezen naam noch de eenheid met de oorkapsels, noch die met den occipitaalboog wordt uitgedrukt ${ }^{1}$ ).

Bij Selachii schijnt het tectum synoticum zich eerst laat te ontwikkelen. Een tot de occipitaalstreek behoorend deel van dit dak, schijnt niet voor te komen. Bij Teleostei vindt men een groot tectum synoticum, dat zich caudaad in het dak van de occipitaalstreek voortzet (Gaupp, 1906).

1) Ook voor andere klassen is in deze geen eenstemigheid bereikt. Zoo vond Sonies (1907) bij eenden- en kippenembryo's een gepaard, zelfstandig, kraakbeenig staafje, dat eerder met het oorkapsel dan met den occipitaalboog vergroeit. Hij spreekt daarom van tectum synsticum. Noordenbos (1904) vond hij verschillende zoogdieren als varkens, konijn, rund een gepaarden aanleg, die het ecrst met den occipitaalboog vergroeit en door hem daarom tectum interoccipitale wordt genoemd. 
Het komt me voor, dat het tectum posterius bij Amphibia e.a. een dubbele herkomst zou kunnen hebben, zoodat men er inderdaad een pars occipitalis met wervelnatuur aan zou mogen onderscheiden, en een dakgedezlte, dat zich in de taenia tecti malialis voortzet of na volkomen ontwikkeling het geheele schedeldak uitmaakt. Soms treedt de occipitaalboog-component op den voorgrond (Urodelen), hetgeen mede aan verregaande reductie van het schedeldak toe te schrijven is. De occipitaalboog heeft bij Urodelen zijn wervelnatuur beter bewaard dan de gelijknamige boog bij Anuren, die, zonals vroeger werd aangetoond, met den praeoccipitaalboog der Urodelen gelijkwaardig is. Dos de caudale en vrije ligging van den occipitaalboog bij Necturus bijv. is het mogelijk, dat ook het dorsale deel van den neuraalboog tot zijn recht komt en een zuiver tectum interoccipitale gevormd wordt (v.g.l. Peeters, 1910: fig. 3, Pl. I). Bij den occipitaalboog der Anuren ontwikkelt zich naar hetgeen Alytes te zien geeft dit dorsale deel niet. Wanneer dit iverkelij! het geval was, zou dit zeker bij Alytes tot uiting moeten komen, waar de occipitaalboog reeds zóó vroegtijdig wordt aangelegd. Het dorsale kraakbeen centrum (larve $7 \mathrm{~m} . \mathrm{M}$.) ligt tegen het caudale deel van den medio-ventralen oorkapselwand op de plaats waar later de crista occipitalis lateralis optreedt. Het tectum posterius ontwikkeit zich eerst later (larve $12 \%$ m.M.) en ligt dan vrij ver rostraal, juist caudaal van den ductus endolymphaticus. Het schijnt mij toe, dat het niet wel mogelijk is hier tusschen occipitaalbooy en tectum posterius direct verband te leggen en ik meen dan ook, dat bij Alytes, en bij Anuren in het algemeen, een tectum synoticum, d.w.z. cen de oorkapsels verbindend en zich vrozglijdig ontwikkelend schede:dakgedeelte gevonden wordt. Bij Anuren zou, indien deze opvatting juist is, de occipitaalbojycompsnen: in het tectum posterins ontbreken, daarentegen hij Urodslan net dakgedeelte bijna geheel gereduceerd zijn.

De breedte van het tectum bij Alytes komt overeen met de opgave van Gaupp voor Rana, watar de achterrand in het vlak van het for. perilymphaticum sup. int. en de voorrand in dat van het for. endolymphaticum ligt. Echter is er bij Alytes in clen loop der ontwikkeling geen sprake van een caudale verschuiving 
der hersenen. In alle stadia vindt men den voorrand van het tectum samenvallen met den oorsprong van den N. VIII. Bij Rana gaat de hersenverschuiving zóover door, dat de voorrand, die eerst over de medulla oblongata ligt, tenslotte over de caudale deelen van de middenhersenen komt te liggen. l'eeters meent als tweede en schijnoorzaak van deze verschuiving een verbreeding van het tectum in sagittale richting te mogen aannemen, veroorzaakt door het uitgroeien van de taenia tecti medialis. Bij Alytes ontbreekt deze taenia en vervalt dus deze factor.

Het ontbreken der taenia tecti medialis is waarschijnlijk niet primitief maar aan reductie toe te schrijven, daar men wel mag aannemen, dat het schedidak als bij Selachii oorspronkelijk geheel kraakbeenig was. Er zijn talrijke Anuren, die evenals Rana twee achterste fontanellen bezitten, maar men vindt er ook verscheidene, die een gesloten schedeldak vertoonen (vgl. de figuren van Parker, 1882). Bij Triton is de reductie blijkbaar nog verder voortgeschreden dan bij Amblystoma, waar Winslow (1898) bij een larve van $39 \mathrm{~m}$. M. een kort mediaal uitsteeksel vond ${ }^{1}$ ).

Eén groote achterste fontanelle vindt men tij Anuren alleen bij Alytes en het is wel eigenaardig op te merken, hoe bij het volwassen dier de smalle fronto-parietalia, die alleen caudaal boven het tectum posterius samenkomen, een zeer onvolkomen dorsale afsluiting van de hersenholte geven, zoodat de voorste en achterste fontanelle, gescheiden door de taenia tecti transversalis, geheel open liggen.

De ontwikkeling van de cristae marginales geschied evenals die der taeniae tecti marginales bij Rana in aansluiting bij het tectum posterius in rostrale richting. Bij Triton treft men geen taeniae of cristae aan.

Rostro-lateraal van het oorkapsel ligt bij Rana de crista parotica, die zich met den processus oticus verbindt. Door Peeters is er terecht opgewezen, dat het ontbreken van den processus oticus bij Alytes duidelijk doet uitkomen, dat de crista parotica alleen van het oorkapsel afkomstig is.

1) Bij Teleostei komt een taenia tecti medialis voor, die zich van uit den taenia tecti transversalis c ntwikkelt en het tectum synoticum niet beic:kt. Bij Lacertaembryo's komt een duidelijke processus ascendens tecti synotici voor, door Gaupp mei de taenia tecti medialis van Rana vergeleken. 


\section{OPERCULUM EN PLECTRUM.}

\section{Stadium II.}

De fenestra ovalis wordt dorsaal door den ventro-medialen rand van het kraakbeen om het laterale boogkanaal, ventraal door den rand van den nagenoeg vlakken, horizontalen oorkapselbodem begrensd. In deze opening treft men het operculum, de pars interna plecti en een opvullend sluitweefsel aan, dat in oudere stadia door bleu de Lyon donkerblauw gekleurd wordt.

De vorm van het operculum is kort-ovaal, schelpvormig en van voren eenigszins toegespitst; de grootste lengte ervan bedraagt 0,8 m.M., de hoogte 0,7 m.M. Het strekt zich tot op $0,3 \mathrm{~m} . \mathrm{M}$. van den voorrand van de fenestra uit en bedekt voor het overige gedeelte deze opening, met welker bovenrand het in nauwe verbinding treedt, geheel. Caudaal zet het operculum zich in een verdikt gedeelte voort, dat zich over den achterrand van de fenestra uitbreidt en waaraan nog geen musculus opercularis gehecht is. Dit uitsteeksel is tegen den oorkapselwand afgeplat en wordt er door een uiterst dun bindweefselstrookje van gescheiden. Ventraal blijft tusschen operculum en vensterrand een spleet bestaan, die gevuld is met het aan elastische vezelrijke sluitweefsel van de fenestra, hetgeen men ook rondom en vóór de punt van het operculum aantreft.

In den rostralen bovenhoek van de fenestra vindt men de in dit stadium reeds gedeeltelijk kraakbeenige pars interna plectri. Even vóór de sluiting van het ovale venster zet zich dit kraakbeen in een kernverdichting voort, die zich nog een eindweegs tot onder het palatoquadratum laat vervolgen en even voorbij den processus ascendens, mediaal van den $\mathrm{N}$. hyomandibularis en tusschen den musculus pterygoïdeus en den musculus depressor mandibulae post. in het omringende weefsel verloren gaat. Het kraakbeen van de pars interna plectri ligt binnen de fenestra tegen het sluitweefsel aan.

Dorso-lateraal ligt tegen het caudale operculumdeel de nog onvertakte, ganglionair-verdikte N. IX. Na splitsing in den R. communicans cum N. VII, den R. pharyngeus en den R. lingualis, volgt eerstgenoemde het operculum op zeer korten afstand lateraal 
en komt eerst ter hoogte van diens voorrand meer vrij te liggen. Daar men het plectrum-kraakbeen dorsaal van dit deel van het operculum aantreft, is de ventrale ligging van den $R$. communicans ten aanzien van het proximale eind van het plectrum eveneens gegeven. Ter hoogte van den voorrand der fenestra buigt het plectrum-proton meer ventro-lateraal af en ligt het dientengevolge weldra mediaal tegen den $R$. communicans aan en meer naar voren zelfs ventraal van dezen zenuwtak. De R. communicans slaat zich dus lateraal en in dorsale richting om den plectrum-aanleg heen en vereenigt zich dorsaal hiervan met den $\mathrm{R}$. hyomandibularis.

De vena jugularis volgt den benedenrand van het kraakbeenig bekleedsel van het lateraalkanaal en ligt juist in den hoek, door het operculum en dezen rand gevormd. De arteria carotis int. loopt van af den voorrand van het operculum evenwijdig met den ventralen fenestrarand, zoodat het kraakbeenig deel van de pars interna plectri tusschen beide bloedvaten in ligt.

\section{Ontwikkeling.}

Een begin van kraakbeenvorming vindt men in het operculum bij een larve van $22 \mathrm{~m} . \mathrm{M}$. in den caudalen benedenhoek van het ovale venster, terwijl men bij een larve van $16 \mathrm{~m} . \mathrm{M}$. den operculumaanleg ter plaatse nog slechts als kernverdichting in het fenestrale weefsel aantreft, zoodat de allereerstekraakbeenvorming tusschen deze beide stadia moet inliggen.

In het laatstgenoemde stadium (16 m.M.) is de ventrale rand van het ovale venster niet scherp kraakbeenig begrensd en ziet men een geleidelijken overgang in het sluitweefsel, dat naar boven toe steeds dunner wordt en tenslotte nog maar enkele cellen dik in het perichondrium van het kraakbeen om het lateraal-kanaal overgaat. Bij de larve van $22 \mathrm{~m} . \mathrm{M}$. is de ventrale vensterbegrenzing caudaal scherp, rostraal daarentegen minder duidelijk. Het kraakbeen van het operculum is op dwarse doorsnede even dik als de smalle strook dichtkernig weefsel, die het met den ventralen vensterrand verbindt, in tegenstelling met het dorsaal gelegen dunne sluitweefsel, dat den vrij grooten afstand tusschen het operculum en den bovenrand van de fenestra vult. 
Uit het bovenstaande is het duidelijk, dat er zekere grond bestat het dichtkernige weefsel als voortzetting van den ventralen oorkapseiwand te beschouwen en het operculum als een daarvan afkomstige kraakbeenplaat.

Bij een larve van $25 \mathrm{~m} . \mathrm{M}$. heeft het operculum zich caudaal reeds over den achterrand van de fenestra uitgebreid.

De pars interna plectri is in ditzelfde stadium als kernverdichting tegen het sluitweefsel van den rostralen bovenhoek van de fenestra zichtbaar.

\section{LITERATUUR.}

Het eerste opireden van een kraakbeenig operculum vindt Gaupp (1893; bij cen Rana fusca-larve van 29 m.M. als een zelfstandige vorming in het sluitweefsel van de fenestra ovalis. Bij cen larve van $31 \mathrm{~m} . \mathrm{M}$. wordt de achterrand reeds bereikt. Later treedt cen voorbijgaande kraakbeenige verbinding met den bovenrand van het ovale venster op (larve $42 \mathrm{~m} . \mathrm{M}$.). De vorming van het plectrum geschiedt tijdens de metamorphose. Bij een larve van $29 \mathrm{~m} . \mathrm{M}$. begint de eerste kraakbeenvorming der pars interna plectri en kan men de voortzetting in het "ligamentum suspensorio-columellare" tot onder het palatoquadratum vervolgen. Het is een kraakbeenvorming in het sluitweefsel van den rostralen bovenhoek van de fenestra. De ventrale rand van het operculum is van den beginne door een tamelijk breede spleet van den onderrand der fenestra gescheiden.

Peeters (1910) bevestigt deze waarnemingen van Gaupp voor Rana fusca, doch kon voor Rana esculenta geen nadere opgaven geven.

Bij een Alytes-larve van 25 m.M. zag Peeters (1910) in overcensiemming met mijn waarneming het operculum dicht bij den caudalen en ven ralen vensterrand zelfstandig optreden; de eerste ontwikkeling valt, zooals pg. 87 gezegd werd, reeds vroeger.

Kothe 11910 , vond bij een Pelobates-larve van $37 \mathrm{~m} . \mathrm{M}$. in de secundaire fenestra ovalis een dun kraakbeenig operculum, waarvan hij de eerste ontwikkeling echter niet na kon gaan; eerst bij een larve van $75 \mathrm{~m} . \mathrm{M}$. trof hij in het rostrale door het 
operculum vrij gelaten deel van het ovale venster den plectrumaanleg aan.

In het algemeen gesproken kan men zeggen, dat bij Anuren het operculum het eerst en geruimen tijd voor de metamorphose ontstaat, terwijl het plectrum (pars interna plectri) eerst veel later juist voor de metamorphose kraakbeenig begint te worden en bij het volwassen dier tot volle ontwikkeling komt. Dit geldt intusschen alleen voor Anura Phaneroglossa. Bij de Aglossa treft men met zeer groote waarschijnlijkheid geen afzonderlijken operculum-aanleg aan en verschijnt het eerste kraakbeen in het ovale venster, naar mij bij een Xenopuslarve bleek, in denzelfden tijd, dat men den plectrum-aanleg zou kunnen verwachten. Ook bij een Pipalarve in de metamorphose is het kraakbeentje nog weinig ontwikkeld en treft men geen vrij operculum aan. Van veel belang is het bij beide vormen te constateeren, dat in het caudale deel van het fenestrale weefsel geen kraakbeen optreedt, maar alleen in het rostrale, gelijk men bij den aanleg van het plectrum verwachten zou $\left.{ }^{1}\right)$. De vraag of men in dit kraakbeenstukje soms een columella mag zien gelijk men die bij sommige Urodelen (Necturus, Proteus) aantreft, laat zich hier door gebrek aan onderzoekingsmateriaal nog niet met zekerheid beantwoorden. Bij Necturus bijv. vindt men volgens Reed (1913) een vroegtijdig verschijnende columella (= operculum: Miss Platt, 1897; Peeters, 1910) van extra-otischen oorsprong, waarbij zich later elementen, afkomstig van den caudalen vensterrand voegen, hetgeen de pars opercularis representeert. Een dergelijke vormingswijze der columella zou bij de Aglossa ook plaats kunnen vinden.

$\mathrm{Na}$ de onderzoekingen van Kingsbury en Reed (1909) e.a., is het wel als zeker aan te nemen, dat het operculum van labyrinthai-

1) Bij een Xenopuslarve van 67,5 m.M. (geen voorpooten) vóór de metamorphose blijft er $+3 / \%$ gedeelte van de fenestra ovalis caudaal open. Bij een Pipa-larve in de metamorphose (totale lengte 20 m.M., staart nog aanwezig, achter- en voorpooten goed ontwikkeld) neemt de kraakbeenige staaf, die zich in een kernverdichting tot aan het blinde tuba-einde voortzet, in sagittale richting ongeveer $4 / 7$ van de vensterruimte in beslag, zoodat eenzelfde ruimte van het ovale venster als bij Xenopus caudaal openblifft. Het proximale eind van het plectrum is in beide gevallen verdikt en legt zich tegen het sluitweefsel aan. Het is niet uitgesloten, dat in dit gedeelte een pars opercularis gezien moet worden. 
ten oorsprong is en bijv. met den hyoidboog niets uitstaande heeft, in tegenstelling met de columella (pars interna plectri der Anura Phanerog!ossa), die van extra-otische origine is en zeer waarschijnlijk tot dezen boog behoort. Kingsbury en Reed (1909) hebben de hyomandibulair-homologie der columella op verschillende gronden aannemelijk gemaakt en Marcus (1910a) wist den samenhang van den columella-aanleg met dien van het hyoid voor Hypogeophis (Apoden) ook inderdaad aan te toonen.

Een veel voorkomende wijze van ontstaan van het operculum bij Urodelen is door histolyse, ,uitsnijding" uit den ventralen oorkapselwand, tegen of tijdens de metamorphose (Amblystoma, Chondrotus tenebrosus: Kingsbury en Reed, 1909; Triton: Fuchs, 1907).

Er zijn echter bij sommige Urodelen door Kingsbury en Reed afwijkende vormingswijzen der gehoorkraakbeentjes aangetroffen, waarvan een tweetal in verband met Pipa 1) nader besproken dient te worden. Bij de Plethodontidae en Desmognathidae heeft de vensterplaat het karakter van columella en operculum beide aangenomen en kunnen deze ook in de ontogenie niet afzonderlijk aangetoond worden (Spelerpes bilineatus). Door uitbreiding van de vensterplaat wordt het ovale venster gesloten. Er zijn volgens Kingsbury en Reed twee redenen om bij deze twee families van een pars opercularis der columella te mogen spreken: $1^{\circ}$ vindt men aan dit deel een prominentia perilymphatica, waarbinnen de recessus perilymphaticus ligt, die men gewoonlijk aan en binnen het operculum aantreft, $2^{\circ}$ is aan deze prominentia een musculus opercularis gehecht. Daar deze beide criteria, naar mij bleek, bij Pipa ontbreken, zal het, indien blijken mocht, dat er bij Pipa en Xenopus geen afzonderlijke operculum-aanleg plaats vindt ") noch zich elementen van den caudalen vensterrand bij het plectrum voegen, zeer meeilijk zijn de aanwezigheid van cen pars

1) De lage ontwikkelingstrap van het perilymphatisch systeem en hei voorkomen van één for. perilymphaticum wijzen, wat het gehoororgaan betreft, op aansluiting van Pipa bij de Urodelen.

2) Er zijn aanwijzingen, dat dit bij Xenopus het geval is. In het rostrale decl van de fenestra ovalis is bij de door mij onderzochte Xenopuslarve slechts éen kraakbeenstukje aanwezig en geen afzonderlijk operculum. 
opercularis bij de Aglossa met zekerheid te bepalen. Behalve een vergelijking met den ontwikkelingsgang bij Plethodontidae en Desmognathidae 1, blijft nog als tweede mogelijkheid een vergclijking met den toestand, zooals men dien bij Cryptobranchus alleghaniensis en Megalobatrachus aantreft, over. Hier kan men larvaal geen afzonderlijk operculum aantoonen en ontbreken volgens genoemde onderzoekers ook de beide zooeven besproken critera.

Het voorkomen van een dergelijke columella zonder pars opercularis (eventueel ook bij Pipa en Xenopus,) behoeft nog niet aan een reductie van het operculum en den daarmede samenhangenden musculus opercularis toegeschreven te worden, maar zou ook zeer goed als primitief beschouwd kunnen worden. In dit geval zou het operculum in de ontwikkelingsgeschiedenis der Amphibia eerst later verschenen zijn. Aan deze onderstelling kunnen volgende overwegingen steun verleenen:

$1^{0}$ Cope (1888) vond bij enkele Permische Stegocephalen (Trimerorhachis Cope en Zatrachys Cope), welke tot de Temnospondyli behooren, de fenestra ovalis gesloten door een ongesegmenteerde columella auris, die naar een inkeping, gevormd door squamosum, supratemporale en tabulare, loopt, waarin waarschijnlijk een soort trommelvlies was uitgespannen. Hier ontbreekt dus het operculum.

$2^{0}$ Larvaal ontbreekt vóor de metamorphose het operculum bij bijna alle Urodelen.

$3^{1}$ Het ontbreekt geheel bij Cryptobranchus en Megalobatra. chus (ook larvaal), die tot de Ichthyoidea, een primitieve groep der Urodelen, behooren.

$4^{0}$ Het ontbreekt ook zeer waarschijnlijk bij de Apoden.

Omtrent dit laatste punt is nog geen volkomen zekerheid verkregen. Marcus (1910a) gaat bij zijn onderzoek van Hypogeophis niet nader op een scheiding in stapes (columella) en operculum in 2 ). Hij houdt echter een deelnemen van het oorkapselblasteem

1) Ook Kingsbury en Reed (1909) doelen op de mogelijkheid van deze vergelijking met verwijzing naar hetgeen Gaupp (1898) omtrent het gehoorbeentje van Pipa mededeelt, hetgeen intusschen alleen betrekking heeft op het volwassen dier.

2) Had hij het onderzoek van Kingsbury en Reed (1909) gekend, waarschijnlijk zou hij aan dit punt meer aandacht geschonken hebben, 
aan de columellavorming voor zeer onwaarschijnlijk, hetgeen in verband met het onderzock van Peter (1898) aangaande Ichthyophis van belang is. Immers deze zag bij deze soort het operculum in aanleg samenhangen met het oorkapselblasteem en de columella. Het is echter te bezien of aan deze waarneming veel waarde gehecht moet worden. Marcus 1910a) vermoedt, dat wanneer Peter over een voldoend aantal horizontale series beschikt had, deze tot soortgelijke resultaten als hij zelf gekomen zou zijn. De eenige serie, die Peter onderzocht, was daarvoor te oud. Bij Ichthyophis moet dus inderdaad nog aangetoond worden, dat er een pars opercularis aanwezig is. De tijdelijke samenhang met het oorkapselblasteem, die het niet onwaarschijnlijk maakt, kan ook secundair zijn.

Op den oorsprong der columella (pars interna plectri) hier nader in te gaan valt buiten het bestek van dit onderwerp, daar door hetgeen bij Anura Phaneroglossa gevonden wordt hoogstens tot een extra-otischen oorsprong van de pars interna plectri besloten mag worden en de belangrijke stadia van de Aglossa mij ontbraken. Goede argumenten voor een hyomandibulair-homologie, behalve het facialis-verloop, geven de Anuren niet. Gaupp (1906, pg. 726) zegt: .,Mit den Hyale hat weder das Operculum noch das Plectrum ontogenetisch etwas zu thun: dasselbe befindet sich beim Auftreten beider noch im vorderen Teil der Orbito-temporalregion in Verbinding mit dem Palato-quadratum". De onmogelijkheid een hyalen samenhang aan te treffen is bij Anuren door de sterk voorwaartsche verplaatsing van het hyoid zoo goed als uitgesloten.

De heerschende opvattingen omtrent de herkomst van operculum en columella bij Urodelen en Gymnophionen kan men met Okajima (1912) als volgt samenvatten:

$1^{10}$ Het operculum is afkomstig van het oorkapsel, de columella van den hyoidboog. (Reichert, Parker, Wiedersheim, Kingsbury en Reed e.a.).

2" Operculum en columella zijn beide afkomstig van den hyoidboog en zijn genetisch één Witebsky, Miss Platt).

3" Operculum en columella zijn beide van labyrinthairen oorsprong (Peter, Fuchs, Okajima). 
Het is wel eigenaardig zulke tegenstrijdige opvattinģen bij verschillende auteurs aan te treffen, maar het is niet mocilijk hiervoor ecn gereede verklaring te vinden. Dikwijls wordt hetgeen bij éen bepaalde species in de ontogenie gevonden wordt, voor denalgemeen grldanden phylogenetischen ontwiklelingsgang verklaard, zon der dat bedacht wordt, dat er mischien geen onderdeel der cmbryologic zooveel schijnbeelden te zien geeft als juist dit. Alleen zij, die voor veel species en genera de ontwikkeling van columelia en operculum konden nagaan, cooals Kingsbury en Reed (1909), zijn in staat zich hierover cen oorcieel te vormen. En er behoort een zekere mate van geluk toe om zooals Marcus (1910a) het verband tusschen columella en hyoidboog inderdaad ontogenetisch te kunnen aantoonen.

Het schijnt mij na de onderzokingen van Kingsbury en Reed en Marcus niet wel mogelijk de hyale herkomst der columella te loochenen.

\section{REGIO ORBITALIS.}

\section{Stadium II.}

De bodem-fontanelle, waarop de hypophyse rust, is op een zeer klein gedeclte na gesloten en de geheele overige schedelbodem kraakbeenig. Onder de hypophyse is het kraakbeen uiterst dun en slechts één cellaag dik, maar craniaal neemt het in dikte toe en gaat geleidelijk in dat van de internasaalplaat over. Slechts een tweetal openingen blijven beiderzijds in den schedelbodem uitgespaard, het foramen caroticum en het foramen cranio-palatinum, waardoor de arteria carotis interna de schedelholte binnentreedt en de ramus palatinus dier arterie den schedel ver laat. Tegen den schedelbodem legt zich het parasphenoïd.

De zijwand is geheel kraakbeenig en door een kraakbeenbrug met het oorkapsel verbonden, zoodat nu door oorkapsel, trabekel en zijwandpijler het foramen proöticum kraakbeenig begrensd wordt. Het foramen oculomotorii, waardoor de N. oculomotorius en de A. ophthalmica naar buiten treden, ligt hier voor een deel onder den processus ascendens direct boven de oorspronkelijke trabekel en is in vergelijking met jongere stadia in verhouding 
aanmerkelijk in lengte afgenomen. De craniale begrenzing van het foramen oculomotorii geschiedt door een dun kraakbeenwandje, dat naar zijn structuur te oordeelen jonger is dan het overige kraakbeen van den zijwand. Hierdoor verschilt het aanzienlijk in dikte van de trabekel en het middengedeelte van den zijwand, die beide reeds langen tijd goed ontwikkeld zijn. De zijwand tusschen for. N. II en III is dientengevolge concaaf. met de uitholling naar buiten gekeerd. Ter hoogte van den voorrand van de taenia tecti transversalis vindt men rechts het for. $N$. IV, dorso-lateraal in den zijwand gelegen juist onder het frontoparietale; links ligt de opening meer caudaal en valt hier met den achterrand dezer taenia samen. In den caudalen hoek van het for. opticum kruist de $\mathrm{N}$. opticus de oorspronkelijke trabekel en neemt slechts een derde gedeelte van de opening in, zoodat er rostraal een groote ruimte overblijft. De zijwand is steeds op de plaats waar ze in de trabekels overgaat zeer veel dunner dan deze, maar voorbij het for. opticum komt hierin verandering en ziet men een geleidelijken overgang tusschen beide. Terhoogte van de commissura quadrato-cranialis ant. eindigt het fronto-parietale, dat den eenigszins naar binnen gebogen bovenrand van den zijwand volgt.

Het dak is door de taenia tecti transversalis vertegenwoordigd, die waarschijnlijk uit de vergroeiing van een ongepaard middenstuk met twee laterale stukken, die zich vanuit den omgebogen zijwand ontwikkeld hebben, ontstaan is. In deze serie heeft deze vereeniging aan de rechterzijde blijkbaar juist plaats gevonden; links is de versmelting reeds volkomen. De achterrand der taenia is vlak, de voorrand convex en valt met den oorsprong van den N. opticus samen. Rostraal van de taenia is de zijwand bijna verticaal en slechts weinig naar binnen gebogen, maar terhoogte van den voorrand der hersenen neemt de buiging meer toe, om tenslotte over te gaan in het dak, dat de schedelholte rostraal begrenst. Het cavum cranii is in verhouding tot de hersenen zeer ruim te noemen. 


\section{Ontwikkeling.}

De vorming van den schedelbodem begint niet lang na de vorming van hee planum internasale, dat als een kraakbeenige verbindingsplaat tusschen de naar elkander toegebogen trabekels, craniaal van de commissura quadrato-cranialis ant. ontstaat en bij een larve van $12^{1}: 2 \mathrm{~m} . \mathrm{M}$. voor het eerst wordt aangetroffen. Het strekt zich rostraal uit, tot waar de N. ollactorii de trabekels kruisen en zet zich voort in een strook kraakbeen, die de nu parallel loopende trabekelhoorns over een korten afstand ventraal verbindt.

De kraakbeenige sluiting van de in dit stadium gevormde fenestra basicranialis anterior vindt plaats in caudale richting, als voortzetting van het planum internasale; tegelijkertijd vindt eveneens kraakbeenvorming plaats in aansluiting bij de mediale zijde der trabeculae, beginnend juist caudaal van het toekomstig for. caroticum (larve $16 \mathrm{~m} . \mathrm{M}$. . Het eerst worden de openingen der art. carotica en later ook de foramina cranio-palatina zichtbaar, daar rondom deze foramina het kraakbeen vroeger aangelegd wordt dan in het overige deel van den schedelbodem. Het for. cranio palatinum is aanvankelijk lang gerekt (fig. 3 en 4, Pl. I) en verkrijgt eerst later den ronden vorm. Ook vóór het planum trabeculare breidt zich het kraakbeen uit, doch slechts in geringe mate, daar de aanwezigheid der hypophyse de kraakbeenvorming langen tijd tegenhoudt.

De chondrificatie van den schedelbodem ventraal van de hersenen vindt op onregelmatige en niet steeds dezelfde wijze plaats. In twee totalpreparaten vind ik nog vór de vorming van het for. cranio-palatinum een breeden transversalen kraakbeen band, ventraal van het diencephalon en juist vóór de reeds gevormde for. carotica; hierdoor wordt de fenestra basicranialis in twee fontanellen gedeeld: de hypophyse-fontanelle en een tweede, daarvoor gelegen.

In een ander totaal-preparaat (32 m.M.l vindt men dezen dwarsband niet, maar is het bodemkraakbeen juist rostraal van het for. cranio palatinum sterk verdikt, terwijl het caudale bodem kraakbeen nog slechts zwak ontwikkeld is. Dat toevallige plaatse- 
lijke druk, door bepaalde hersengedeelten uitgeoefend, op de wijze van kraakbeenvorming in den schedelbodem van invloed is, mag wel aangenomen worden. Zoo vond ik in een totaalpreparaat de aanrakingsvlakken der hemispheren van het telencephalon met den bodem nog niet in kraakbeen overgegaan, maar het tusschen beide in gelegen gedeelte wel. Het deel van den bodem onder de hypophyse gelegen, dat het langst open blijft, illustreert dit eveneens.

In het eerste stadium was de zijwand voor het grootste deel nog vliezig met ruime openingen voor den $N$. II en III. De kraakbeenvorming geschiedde, gelijk gezegd werd, in aansluiting bij den zijwandpijler in rostrale richting. Het kraakbeen van deze laterale zijwandlijst was tot voorbij den $\mathrm{N}$. opticus te vervolgen, waar het zich langzaam in het vliezige deel van den zijwand verloor. Bij een larve van $9^{1} / 2$ m.M. treft men er nog tot juist vóór de commissura quadrato-cranialis ant. kraakbeen in aan. Het trabekel-krakbeen is hier op dwarse doorsnede in de lengte gerekt en naar een aantal boven elkander gelegen deelingswandjes te oordeelen opwaarts gegroeid. Toch blijft er tusschen de zijwandlijst en dit omhoog gegroeide kraakbeen een nog niet gechrondificeerd deel van den zijwand over, dat op het punt staat in kraakbeen over te gaan. Bij cen larve van $12^{1} \geq \mathrm{m} . \mathbf{M}$. is de versmelting van beide volkomen, zoodat het niet mogelijk is na te gaan, welk aandeel de trabekel en welk de zijwandlijst aan deze vorming genomen heeft. De overgang tusschen beide is vooral ter hoogte van de commissura quadrato-cranialis ant. zeer geleidelijk en het mag wel aangenomen worden, dat hier de chondrificatie van de trabekel af naar boven tne plaats gevonden heeft.

Bij een larve van $9 \frac{1}{2} \mathrm{~m} . \mathrm{M}$. zijn de for. N. II en III nog niet aan alle zijden kraakbeenig begrensd. Het scheidingswandje tusschen beide foramina en het wandgedeelte vór het for. opticum gelegen staan op het punt in kraakbeen over te gaan, hetgeen dan ook bij cen larve van $121 / 2 \mathrm{~m} . \mathrm{M}$. geschied is. Het is niet met zekerheid uit te maken of zich dit kraakbeen van uit de trabekel of van uit de zijwandlijst ontwikkelt, maar naar serie 13, 14 en 15 te oordeelen zou men zeggen, dat dit wanddeel in aansluiting bij beide in kraakbeen overgaat. Het for. opticum, waarvan de diameter door de opening in den vliezigen zijwand reeds van te voren 
gegeven was, wordt nu spoedig evenals het tor. oculomotorii door kraakbeen omgeven. Het for. opticum heeft bij een larve van 25 m.M. dezelfde lengtedoorsnede als bij een larve van 53 m.M.; het for. oculomotorii daarentegen wordt door het caudaal uitgroeien van den wand, die het van het for. opticum scheidt, verkort en verkrijgt dus eerst later zijn definitieve grootte. Het rostrale begrenzingswandje van het for. oculomotorii makt bij een larve van 53 m.M. den indruk nog sinds korten tijd aanwezig te zijn.

De verhooging van den zijwand, die doorgat tot de hersenen ook dorso-lateraal kraakbeenig begrensd worden en de zijwand naar binnen toe omgebogen is (fig. 3, Pl. I), vindt plaats van uit de laterale zijwandlijst en is bij een larve van $22 \mathrm{~m} . \mathrm{M}$. reeds zeer goed ontwikkeld.

Resumeerend kan men zeggen, dat de zijwand-ontwikkeling van uit twee hoofdcentra plaats vindt, de trabekel en de zijwandlijst. Beide zijn bij Alytes reeds vroegtijdig aanwezig, de trabekel natuurlijk het eerst. Door de rostrale ontwikkeling van de zijwandlijst, beginnend bij den reeds vroegtijdig aangelegden zijwandpijler, vindt ter hoogte van de commisura quadrato-cranialis ant. vereeniging met het trabekelkraakbeen plaats. Bijna gelijktijdig gaan ook de door beide omsloten deelen van den vliezigen zijwand in kraakbeen over, waardoor de foramina N. II en III kraakbeenig begrensd worden, hetgeen bij het eerste spoedig, bij het laatste eerst later definitief geschiedt. Door het uitgrocien van kraakbeen van uit de zijwandijist in dorsale richting en ter hoogte van de commissura quadrato-cranialis ant. van uit de trabekel neemt de zijwand in hoogte toe.

Het foramen proöticum mist bij een larve van $121 / 2 \mathrm{~m} . \mathrm{M}$. nog zijn dorsale kraakbeenige begrenzing en verkrijgt dit eerst bij een larve van 16 m.M., waar men duidelijk kan waariemen, dat dit kraakbeenbrugje een voortzetting is van het binnenwaarts gebogen deel van den zijwand, dat zich met het oorkapsel verbindt.

De zijwand is, zooals gezegd werd, aanvankelijk laag en begrenst de hersenholte meer ventro-lateraal, doch neemt in den loop der ontwikkeling in hoogte toe. Dit is waarschijnlijk de oorzaak, dat in jonge stadia door mij geen foramen trochleare 
werd aangetroffen, daar de doorboring van den vliezigen zijwand, mede in verband met de fijnheid der zenuw, zich gemakkelijk aan het oog onttrekt. Doch ook in oudere stadia (22 m.M.) was het niet mogelijk een foramen trochleare te vinden; wel ziet men bij een larve van $22 \mathrm{~m}$.M. even rostraal en dorsaal van het for. opticum een doorboring, waardoor een takje van de vena jugularis de schedelholte betreedt.

Daar de ontwikkeling van de taenia tecti transversalis bij larven van meer dan $30 \mathrm{~m} . \mathrm{M}$. gevonden wordt, kan ik door het ontbreken van series en in dit opzicht betrouwbare totaalpreparaten geen nadere opgaven hieromtrent doen. Door het wegprepareeren der hersenen is het niet met zekerheid te zeggen of bij het in fig. 3, Pl. 1, afgabeelde chondrocranium de taenia ook in het middengedeelte reeds kraakbeen-ontwikkeling vertoonde.

\section{LITERATULIR.}

Omtrent de sluiting van den bodem van de fenestra basicranialis komen mijne waarnemingen met die van Peeters (1910) voor Rana fusca en esculenta en Alytes overeen. Het for. caroticum wordt aangelegd vóór het for. cranio-palatinum en de sluiting van de hypophysen-fontanelle is vóor de metamorphose bijna geheel of geheel voltooid, al is ook het kraakbeen ter plaatse uiterst dun. Ook totaalpreparaten van Rana fusca bevestigden dit en stellen Peeters, wiens waarnemingen op deze punten van Gaupp's bevindingen bij Rana fusca ') verschillen, in het gelijk. Daar Peeters (1910, pg. 129) dit uitvoerig bespreekt, kan hier met een verwijzing naar zijn verhandeling volstaan worden. Een transversale bandvorming, die ik één enkele maal waarnam en die de fenestra basicranialis in twee fontancllen declt, vond ik voor andere vormen niet beschreven.

De vorming van het planum internasale geschiedt bij Rana vroeger dan bij Alytes; bij Rana (Stöhr, 1882) schijnt tegelijk met het kraakbeenig worden der trabekels ook de vereeniging

1) Gaupp (1893) vond: le het for. caroticum wordt eerst na het for. cranio-palatinum gevormd, 2c de hypoplyyse fontanelle is ecrst na de metamorphose gesloten. 3e het deel van den bodem, dat het laatst in kraakbeen overgaat, ligt niet direct onder de hypophyse, maar meer rostrial. Dil laatste kon ik bij Alvtes niet nagaan. 
van deze beide plaats te vinden. $B i j$ een larve van $7,5 \mathrm{~m} . \mathrm{M}$. (Stöhr, fig. 18, Taf. III) is de verbinding reeds tot stand gekomen. In een totaalpreparaat van Rana fusca nam ik waar, hoe reeds vóor de vorming van het planum trabeculare de beide trabekels rostraal samentreffen en het planum internasale in aanleg is. Bij Alytes daarentegen ontstaat het planum trabeculare vóor het planum internasale. Bombinator schijnt zich in dit opzicht bij Rana aan te sluiten (vgl. Goette, 1875, Taf. XVIII, fig. 324).

Bij Rana begint volgens Gaupp en Peeters de zijwandontwikkeling op twee plaatsen, n.l. bij den zijwandpijler ter hoogte van den processus ascendens en ter hoogte van de commissura quadrato-cranialis ant. Nadat de $N$. trigeminus kraakbeenig nauw omsloten is, worden de beide kraakbeenige verhevenheden door een dorsale kraakbeenige lijst (,dorsale Randspange") verbonden, waarbinnen de nog vliezige zijwand als in een raam is uitgespannen ; $d \geq$ kraakbeenvorming binnen dit raam geschiedt deels uitgaande van de trabekel, deels van de "dorsale Randspange", waarbij het for. opticum wordt uitgespaard. Alvorens deze spang zich nog ontwikkeld heeft, vindt de verbinding van den zijwandpijler met de taenia tecti marginalis plaats en wordt het for. proöticum dorsaal kraakbeenig begrensd.

Peeters (1910) uitte het vermoeden, dat de ontwikkeling van den zijwand bij Alytes een andere zou zijn dan die van Rana en bij de vorming de trabekels als uitgangspunten zouden dienen. Hoewel er in de zijwandontwikkeling bij Alytes verschilpunten met Rana zijn, kan men toch niet zeggen, dat de onderstelling van Peeters bewaarheid is geworden. Een zijwandontwikkeling van uit de trabekel kan waarschijnlijk alleen voor het gedeelte ter hoogte van de commissura quadrato-cranialis ant. aangenomen worden. Voor het overige vindt men bij Alytes een lateraal gelegen, vroegtijdig kraakbeenige zijwandlijst, van waaruit de zijwand verhooging plaats vindt. Van een "dorsale Ranáspange" te spreken lijkt mij door de laterale ligging van deze lijst niet gewenscht. Ook bij Alytes vindt men een hoewel minder scherp begrensd raam, waarvan het daarbinnen gelegen vliezige zijwanddeel op overeenkomstige wijze als bij Rana chondrificeert.

Een verschilpunt met Rana bestaat echter hierin, dat men 
een nauwe omsluiting van den $N$. III bij de ecrste ontwikkeling van den zijwand van Alytes niet aantreft, maar eerst zeer vecl later de sagitiale diameter van de opening kleiner wordt. Reeds vroeger werd erop gewezen, dat vergeleken met Rana, waar de "dorsale Randspange" bij een larve van $30 \mathrm{~m}$.M. ontwikkeld is, de zijwand bij Alytes vroegtijdig chondrificeert.

De verbinding van den orbito-temporalen schedelwand met het oorkapsel tot vorming van het for. proöticum toont bij Alytes groote overeenkomst met hetgeen men bij UIrodelen, met name bij Triton Gaupp, 1906 aantref. Bij Rana, waar zelfstandige taeniae tecti marginales vooikomen, gaan deze in den zijwand over en komt de directe verbinding met de orkansels eerst na hun versmelting met de taeniae tot stand. Chronologisch geschiedt de verbinding van den zijwandpijler met de tonna tecti marginalis bij Rana, vóórdat de ,dorsale Randspange" nog annwezig is; bij Alytes daarentegen wordt eerst de zijwand kraakbennig larve $7 \mathrm{~m}$. M. en volgt eerst later de verbinding van zijwand en oorkapsel (larve $16 \mathrm{~m} . \mathrm{M}$.)

De ligging van het foramen trochleare, dat zich bij larven tot $25 \mathrm{~m} . \mathrm{M}$. door de fijnlieid der zenuw aan de waarneming onttrok, komt overeen met die bij ?ana (vg!. Gaupp, 1893, fig. 24, Pl. XIV). In genoemde figuur treft men nog cen tweeds opening aan, dorsaal en rostraal van het for. opticum, die door Gaupp niet nader omschreven wordt; ook Pecters vond bij Nites soms geen, soms twee openingen, de een boven het for. octlomotorii, de ander boven het for. opticum, doch kon niet met zekerheid uitmaken, welk van beide roor den N. IV moest dienen. Bij cen larve van 25 m.M. b.v. blijkt, dat de caudale het for. trochleare vertegenwoordigt, terwij! dion het rostrale cen takje van de vena jugularis de schedethole beirecti. Later slutitich latstgenoemd foramen, dat dus slechts tijdelijk bestaat, zoodat men in stadium Il links nog slechts een rest van de opening met pigment gevuld aantreft en rechts het foramen verdwenen is.

Merkwandig i*, dat bij oudere larven de N. trochlearis behalve den kraukbenigen zijwand ook het fronto-parietale doorboort. In stad. II is dit niet het geval, maar wel bij een larve van 62 m.M. en bij cen van $55 \mathrm{~m} . \mathrm{M}$. in de metamorphose (bij deze laatste 
alleen rechts). Dit hangt ongetwijfeld samen met de laterale uitbreiding van het fronto-parictale, dat nu en dan tot voorbij de opening voor den N. IV reikt en een foramen voor deze zenuw moet openlaten.

Door Drüner (1900) werd voor Salamandra maculosa en voor Triton taeniatus (somtijds) aangegeven, dat de N. IV het parietale doorboort. Coghill (1902) vond hetzelfd z bij Amblystoma tigrinum en Gaupp (1911) trof het behalve bij Triton taeniatus ook bij Spelerpes bilineatus en Desmognathus fuscus aan. Bij Triton e.a. loopt de zentw soms in den naad tusschen parietale en orbitosphenoïd, soms ook wordt het parietale doorboord.

Dezen wisselenden loop van den N. IV bij Urodelen schrijft Gaupp toe aan de geringe ontwikkeling van het primordiaalcranium bij deze groep, die tengevolge heeft, dat het dekbeen sterk ontwikkeld is en cen groot aandeel aan de vorming van den schedelzijwand heeft. Zoo zegt hij pg. 406; "In dieser Hinsicht haben die Ânuren ein primitiveres Verhalten bewahrt; bei ihnen ist die primoidiale Schädelseitenwand vollständiger, und so tritt dann bei ihnen (Rana, Bombinator, Pelobates, Alytes), der Trochlearis durch ein kleines, selbstständiges Foramen in dieser Schädelseitenwand, damit an das Verhalten bei Selachiern und Knorpelganoïden erinnerend."

Alytes doet ons zien, dat, zooals reeds meer gebleken is, inderdaad ook in dit opzicht geen scherpe grens tusschen Urodelen en Anuren te trekken valt. Terwijl men hier bij Alytes een zeer goed ontwikkelden schedelzijwand met een foramen vindt, treft men somtijds bovendien nog een doorboord fronto-parietale aan. Een zelfstandig foramen in den schedelzijwand schijnt ook bij Urodelen somtijds voor te komen, gelijk Osawa (1902) voor Cryptobranchus japonicus aangeeft.

De verklaring van Gaupp omtrent het ontstaan van het foramen in het parietale is in dien vorm dus niet wel houdbaar. Immers Alytes doet zien, dat het parietale zich wel degelijk ventrolateraal kan uitbreiden, ondanks een goed ontwikkelden, kraakbeenigen zijwand. De geringe ontwikkeling van dezen wand bij Urodelen kan dus niet de eenige oorzaak zijn. Bovendien geeft Siredon, (zie Gaupp, 1911, pag. 406, fig. 4) cen duidelijk voorbeeld, 'ioe 
een plat parietale, dat zich weinig of niet ventrolateraal uitstrekt, door den N. IV doorboord wordt.

Als algemeene regel zou men dit kunnen zeggen: het parietale strekt zich met zijn lateralen rand tot in de onmiddelijke nabijheid van de trochlearis-doorboring uit. Dit foramen kan in een vliezigen of een kraakbeenigen zijwand gevonden worden. Nu schijnt door welke oorzaak ook het parietale neiging te vertoonen zich over dit foramen uit te breiden en moet in dat geval natuurlijk een opening voor de zenuw vrijlaten.

Normaal is derhalve, dat het for. trochleare bij Urodelen in den naad tusschen parietale en orbitosphenoid gevonden wordt en bij Anuren juist tegen den rand van het fronto-parietale aan ligt. Als variatie vindt men somtijds bij sommige exemplaren hetzij onder Urodelen of Anuren een doorboord parietale. Bij enkele Urodelen schijnt dit constant voor te komen.

De onderstelling van Peeters, dat ook bij zijn jongste larve 125 m.M.) de taenia tecti transversalis aanwezig zou zijn, wordt door mijn preparaten niet bevestigd. Bij een larve van 25 m.M. is er van deze taenia nog geen spoor te vinden. In een totaalpreparaat van een larve van $32 \mathrm{~m} . \mathrm{M}$. ziet men den aanleg ervan, lateraal bij den zijwand aansluitend; of het middenstuk reeds in dit stadium aanwezig is, valt door het wegprepareeren der hersenen niet met zekerheid te zeggen (fig. 3, Pl. I). Bij Rana fusca kon Peeters reeds bij een larve van $22 \mathrm{~m}$. M. de taenia aantreffen, die bij een larve van 29 m.M. voltooid is.

De ligging van de taenia tecti transversalis herinnert aan die der Teleostei Salmo). Ze ligt bij Alytes dicht boven de epiphyse en vertoont ook bij Salmo een betrekking tot het corpus pineale, al ligt ze hier juist caudaal ervan (Epiphysarleiste, Gaupp, 1906). $\mathrm{Z}_{\mathrm{ij}}$ vormt de caudale begrenzing van de voorste dakfontanelle, die zich bij Salmo sluit; bij Selachii vindt men hier de praefrontale opening. De voorste dakfontanelle kan bij sommige Anuren blijkens de afbeeldingen van Parker 11881) groote afmetingen aan nemen. 


\section{E. REGIO ETHMOIDALIS, SUPRAROSTRALIA.}

\section{Stadium II.}

Ter hoogte van de commissura quadrato-cranialis ant. maken de $\mathrm{N}$. olfactorii zich van het telencephalon vrij en begeven ze zich nagenoeg parallel voorwaarts, tot ze juist caudaal van de praecerebraalplaat de lateraal gelegen foramina olfactorii bereiken. De zijwand is ter hoogte van genoemde commissuur vrij sterk binnenwaarts gebogen (fig. 22, Pl. IV), hetgeen meer rostraal tot een mediale vereeniging leidt, waardoor een dak gevormd wordt en de reukzenuwen dus in een alzijdig begrensde en met slijmweefsel gevulde ruimte loopen, die rostraal door de praecerebraalplaat wordt afgesloten. Deze plaat, waarin men vorm en ligging der trabekelhoorns nog duidelijk herkennen kan, heeft een vrij groote dikte bereikt en sluit het cavum internasale caudaal af. De begrenzing van dit op dwarse doorsnede in verticale richting lang gerekte cavum internasale geschiedt door een viertal wanden, waarvan de herkomst door vorm en grootte der kraakbeencellen niet moeilijk nagegaan kan worden. De zijwanden worden door de trabekelhoorns gevormd, die juist voor de praecerebraalplaat dorsaa! door later gevormd kraakbeen sterk verhoogd zijn 1). Deze verhooging gaat rostraal geleidelijk in de cornua over. Dorsaal zijn deze verhoogde trabekelhoorns en ook nog over een korten afstand de cornua zelf door een dun kraakbeenbandje verbonden, dat zich tot ter hoogte van de aanhechting van het ligamentum quadrato-ethmoïdale voortzet. Dit kraakbeenstrookje vormt de dorsale begrenzing van het cavum, terwijl als ventrale wand een vrij stevige kraakbeenband optreedt, die in aansluiting bij de internasaalplaat de cornua verbindt en rostraal in een ligament overgaat, dat zich na splitsing aan de beide cornua-einden hecht

Op de aanhechtingsplaats van het ligamentum quadrato-ethmoidale is de trabekelhoorn zijdelings verbreed (processus lateralis). Juist vóór den processus lateralis eindigt de ventrale kraakbeenige verbinding der cornua en komen de hoorns dus geheel vrij te liggen. De cornua worden distaal, waar ze zich bijna rechthoekig naar beneden buigen, door een dorsaal ligament verbonden, dat

1) Vgl. voor een jonger stadium fig. 24 a, Pl. IV. 
zich over de mediale uitsteeksels der suprarostralia uitbreidt en beide ook lateraal verbindt. De suprarostralia zijn door een smalle strook niet kraakbeenig weefsel, dat zich met bleu de Lyon blauw kleurt, bewegelijk aan de cornua trabeculae gehecht.

Dorsaal van de commissura quadrato-cranialis anterior, ter halver hoogte van den zijwand, vindt men een laterale verdikking, die als processus antorbitalis zelfstandig wordt, welke kraakbeenspang het reukorgaan caudaal en dorso-lateraal begrenst en rostraal tot ter hoogte van het foramen olfactorii vervolgd kan worden. De musculi obliqui sup. en inf. hechten zich aan de caudale zijde van den processus antorbitalis. De ramus internus narium (tak van den $R$. orbito-nasalis s, ophthalmicus $V$ ) begeeft zich juist ciorsaal van deze zijwandverdikking naar voren en wordi spoedig met de gelijknamige arterie in een kort kanaal ingesloien. Miediaal wordt dit kanaal begrensd door den zijwand, lateraal door den processus antorbitalis, ventraal door beide en dorsaal door een voor het grootste deel nog vliezig dak (fig. 22, Pl. IV) ${ }^{1}$ ). Daar, waar de processus antorbitalis zich van den zijwand losmaakt, zendt het rechts een kraakbeenbandje schuins naar voren, dat zich over den $\mathrm{R}$. internus narium met den zijwand verbinden zal, hetgeen thans nog niet geschied is. Links is daarentegen deze vereeniging reeds tot stand gekomen, maar is er nog geen kraakbeenige, wel vliezige, verbinding met den processus antorbitalis.

Het dak van de neusholte is als een dorso-laterale kraakbeenlijst terweerszijden van de praecerebraalplaat en het dorsale verbindingskraakbeen der cornua aanwezig. Het is rostraal tot aan den processus lateralis der cornua te vervolgen, caudaal eindigt het ter hoogte van de achterzijde der praecerebraalplaat en der foramina olfactoria en gaat hier over in een voorkraakbeenige weelselstrook, die bij den bovenrand van den zijwand aansluit. Meer naar achteren ziet men links weldra weer kraakbeen optreden, het boven genoemde kraakbeenbandje, dat aansluiting zoekt bij den processus antorbitalis.

De deelen van het neusskelet, die hier nog slechts als kern-

1) De kraakbeenvorming in dit dak geschiedt zelfstandig, hetgeen rechts in het caudale deel in beginsel te zien is en door serie 20 bevestigd wordt. 
verdichting aangeduid zijn en tijdens en na de metamorphose hun volle ontwikkeling verkrijgen, blijven hier buiten bespreking.

Aan de suprarostralia kan men onderscheiden: een ongepaard middenstuk, dat de mondopening rostraal begrenst, twee goed ontwikkelde vleugels en een paar dorsale, mediale uitsteeksels, die met de cornua trabeculae bewegelijk verbonden zijn (fig. 3 en 4 . P1. 1). De vleugels zijn lateraal verbreed en van twee uitstecksels voorzien, een dorso-lateraal, waaraan een twcetal spieren insereeren (vgl. stadium II. Palatoquadratum). Juist achter het middenstuk ligt in de mediaanlijn een bloedvat, waarvan de herkomst in verband met de vergelijking der suprarostralia met die van andere Anuren belangrijk is. De rami palatini van de beide art. car. int., die zich binnen de schedelholte naar voren begeven en door de fora mina cranio palatina deze ruimte verlaten, loopen daarna ventraal van den schedelbodem en juist mediaal van de oorspronkelijke trabekels. Van deze beide takken is de rechter rostraal zwakker ontwikkeld dan de linker en deelt zich terhoogte van de uitwendige neusopening in een aantal fijne takjes ${ }^{1}$ ). De linker tak doet dit niet, maar verplaatst zich, ongeveer terhoogte van het punt, waar het ventrale verbindingskraakbeen der cornua in het ligament overgaat, naar het midden. Meer naar voren ligi het bloedvat weldra boven genoemd ligament en buigt zich tenslotte terplaatse, waar de cornua met de suprarostralia verbonden zijn, ventraal om. In de mediaanlijn der beide dorsale, mediale uitsteeksels der suprarostralia loopend, begeeft de arterie zich juist achter den achterrand van het middenstuk naar beneden en bereikt terhoogte van de eerste rij mediale palatinum-tandjes de huid, waar zij zich verdeelt.

De rami interni narium $\mathrm{V}$ volgen na het verlaten van het orbitonasaalkanaal en het kruisen van de $\mathrm{N}$. olfactorii de trabekelhoorns steeds dorso-lateraal (fig. 23, Pl. IV), buigen zich bij den overgang van de cornua in de mediale uitsteeksels der suprarostralia mede ventraal naar beneden om en verdeelen zich in de huid.

1) Vgl. fig. 23 en 24, Pl. IV, voor jongere stadia. 


\section{Ontwikkeling.}

De ligging der hersenen ten opzichte der cornua trabeculae in het eerste stadium is zoodanig, dat de voorrand van het telencephalon zich tot even voorbij het einde der cornua uitstrekt. De zenuwvezels van den $\mathrm{N}$. olfactorius gaan direct in het epitheel van het reukorgaan, dat ter weerszijden tegen de hersenen aan gelegen is, over. De cornua dragen hier dus voor een deel het telencephalon. Bij een larve van $121 \% \mathrm{~m} . \mathrm{M}$. strekt de hersenvoorrand zich tot voorbij de juist gevormde internasaalplaat uit, terwijl de trabekelhoorns over een afstand van $0,3 \mathrm{~m} . \mathrm{M}$. vóór de hersenen te vervolgen zijn. Bij een larve van $16 \mathrm{~m} . \mathrm{M}$. neemt de lengte der cornua toe en bedraagt deze afstand $0,65 \mathrm{~m} . \mathrm{M}$; bij een larve van $22 \mathrm{~m} . \mathrm{M}$. is deze reeds $1.3 \mathrm{~m} . \mathrm{M}$. enz. Er valt dus in den loop der ontwikkeling een uitgroeien der cornua, die nagenoeg evenwijdig loopen, waar te nemen.

Door de vorming van de internasaalplaat tusschen het gedeelte, waar de trabekels het sterkst naar elkander toe gebogen zijn, wordt een rostrale begrenzing van de fenestra basicranialis ant. verkregen. In aanleg ziet men deze plaat reeds bij een larve van $91 / 2 \mathrm{~m} . \mathrm{M}$., terwijl ze bij een larve van $12^{1} \mathrm{~m} . \mathrm{M}$. in kraakbeen is overgegaan. Rostraal zet ze zich bij een larve van 16 m.M. in de kraakbeenstrook, die de cornua ventraal verbindt, voort.

De trabekelhoorns en de internasaalplaat vormen de basis voor de toekomstige praecerebraalplaat. Bij een larve van $16 \mathrm{~m}$.M. ziet men den kraakbeenigen aanleg van deze plaat als een op de internasaalplaat tusschen de cornua gelegen verhevenheid, die zich rostraal links en rechts op de trabekelhoorns voortzet (fig. 24 c, b, a, Pl. IV). De kraakbeenvorming vindt blijkens kleur en grootte der cellen van uit de internasaalplaat en van uit de kraakbeenverhevenheden, die zich juist vóór de $\mathrm{N}$. olfactorii op den rug van de trabekelhoorns bevinden, en in aansluiting bij deze plaats. Men zou in verband hiermede wellicht van een internasaalplaatcomponent en van hoorncomponenten kunnen spreken, die door vereeniging de praecerebraalplaat vormen. Er wordt ook in het voorkraakbeenige stadium larve $121 \%$ m.M.) geen fenestra ethmoïdalis aangetroffen. 
De verhevenheiden op de cornua (fig. 24, T.V.) overgroeien de $\mathrm{N}$. olfactorii in caudale richting en verbinden zich met den zijwand; de foramina olfactoria worden bij een larve van $22 \mathrm{~m}$.M. aangetroffen.

Den aanleg van den processus antorbitalis treft men bij een larve van $22 \mathrm{~m} . \mathrm{M}$. dorsaal van de commissura quadrato-cranialis ant. ter halver hoogte van den zijwand als een laterale verdikking aan, die zich als een rostraal gericht spangetje hiervan vrij maakt. De musculi obliqui oculorum hechten zich caudaal aan dezen pro cessus.

Van de suprarostralia is het mediane deel bij een larve van $12 \%$ m.M. nog niet kraakbeenig, wel de vleugels en de verbindingsstukken met de cornua. Bij een larve van $16 \mathrm{~m}$. M. vindt men een uiterst dun kraakbeenig middenstuk zonder naad.

\section{LITERATUUR.}

Born (1876) zag de praecerebraalplaat bij Pelobates ontstaan door de ontwikkeling van twee pijlers, door hem "Produkte der Trabekel" genoemd, die een aanvankelijk met slijmweefsel gevuld venster omsluiten, dat later door kraakbeen gevuld wordt.

Gaupp (1893) heeft een soortgelijke ontwikkeling bij Rana fusca waargenomen, waar de praecerebraalplaat uit drie componenten bestaat, n.l. de twee ethmoïdaalpijlers (larve $21 \mathrm{~m}$. M.), die zich op de internasaalplaat verheffen en een mediale fenestra ethmoïdalis (praecerebralis) omsluiten, en een mediaal sluitstuk, dat door het kraakbeenig worden van het fenestrale slijmweefsel bij een larve van $31 \mathrm{~m} . \mathrm{M}$. aangetroffen wordt:

Peeters (1910) kon de opgaven van Gaupp omtrent Rana fusca bevestigen en preciseeren. De ethmoïdaalpijlers ziet hij reeds bij larven van $17 \mathrm{~m} . \mathrm{M}$. De vorming van het for. olfactorium schrifft hij toe aan het uitgroeien van den zijwand over den N. olfactorius den ethmoïdaalpijler tegemoet.

Rana esculenta wijkt, zooals Born het eerst beschreef en Peeters bevestigde, van Pelobates en Ran 1 fusca in de praecerebraalplaatvorming af. Hier komt in de ontwikkeling geen fenestra praecerebralis voor en wordt het eerst een kraakbeenige verhevenheid 
op de internasaalplaat aangetroffen. Of de vorming der foramina olfactoria als bij Alytes plaats vindt, moet ik in het midden laten. Alytes schijnt zich wat beide eerstgenoemde punten aangaat nauwer bij Rana esculenta dan bij Rana fusca aan te sluiten.

Bij Urodelen wordt de fenestra praecerebralis niet gesloten.

De aanleg van het planum antorbitale ') wordt bij Rana fusca en esculenta in den hoek tusschen de commissura quadrato-cranialis ant. en den zijwand aangetroffen. Bij Alytes ligt dit punt meer dorsaal ter halver hoogte van den zijwand.

De insluiting van den ramus internus narium in een kanaal vindt men bij Rana niet; men treft hier een foramen orbitonasale aan, waardoor de $\mathrm{N}$. orbito nasalis $\mathrm{V}$ zich van uit de orbita naar de neusholte begeeft.

De processus laterales der cornua, die door ligamenten met de processus quadrato-ethmoïdales verbonden zijn, vond ik in totaalpreparaten van Rana fusca niet. Ook Gaupp beeldt ze in zijn reconstructies niet af. Bij Rana esculenta komen volgens figuur 6 , Pl. 1 (Peeters, 1910) dergelijke uitwassen aan de trabekelhoorns voor en volgens Parker's figuren zijn ze vooral goed ontwikkeld bij Pseudis parodoxa, Calyptocephalus gayi, Cycloramphus culeus, Hyla spec. en Bufo chilensis.

Het kraakbeen, dat bij Alytes de cornua ventraal verbindt, is door Peeters terecht met het ligamentum intertrabeculare inferius van Rana vergeleken. Of er inderdaad bij Rana een ligamentum intertrabeculare superius voorkomt, mag in twijfel getrokken worden. Gaupp (1893, pg. 417) zegt ervan, dat het ,,aber weniger ein dichterer Strang, wie das Ligamentum intertrabeculare inferius, als vielmehr ein Pigmentzellen-Zug ist". Men kan dit, dunkt me, bezwaarlijk een ligament noemen. Bij Alytes vindt men wel een dorsaal ligament, dat de distale cornua-einden verbindt, maar niet in de streek der neusholten.

Wanneer men de suprarostralia van Rana fusca van voren beziet, vallen volgens Peeters (1910) twee foramina in het oog,

1) In jongere stadia voor de metamorphose komt de naam processus antorbitalis meer met de werkelijkheid overeen. 
dic bloedvaten doorlaten 1). In totaalpreparaten zijn deze door boringen duidelijk, daarentegen, naar mij zelf bleck, in coups niet zoo in het oog vallend, hetgeen verklaart, dat Gaupp ze niet vermeldt en waarschijnlijk over het hoofd zag \%). Intusschen kon $\mathrm{ik}$ in de drie door mij onderzochte series alleen rechts de door boring waarnemen, hetgeen Peeters een enkele maal evenzeer aantrof.

Bij Rana esculenta komen er volgens Peeters nog twee groote, laterale, door een vlies gesloten vensters bij en een mediaal, dat een overblijfsel schijnt van den grooten inham, die bij Rana fusca de beide suprarostralia scheidt (Peeters, 1910, fig. 11, P1. 1). Nu zijn volgens Peeters (pg. 154) ,deze laterale open plekken en de foramina om de bloedvaten evenzeer resten van tijdens de phylogenese verloren gegane scheidingen, als de mediale open plek bij Rana esculenta cen overblijfsel is van den medialen inham bij Rana fusca". Peeters leidt nu van den toestand bij Alytes, waar de vleugels door een grooten inham van de mediale uitsteeksels gescheiden zijn, de suprarostralia der Ranidae af ,door kraakbeenige vereeniging der verschillende deelen in meerdere of mindere mate". Het spreekt van zelf, dat er voor de bloedvaten openingen moesten blijven. Dit laatste nu is in strijd met de feiten. Bij de beschrijving van het tweede stadium van Alytes heb ik erop gewezen, dat alleen de linkertak van den $R$. palatinus zich tot aan het middenstuk der suprarostralia vervolgen laat en het rechterbloedvat zich reeds eerder in een aantal fijne takjes verdeelt. De linker palatinustak ligt in de mediaanlijn tusschen de beide dorso-mediale uitsteeksels der suprarostralia en niet lateraal. Bij Rana fusca en esculenta en blijkens Parker (1881) ook bij andere Raniden (R. pipiens, R. clamata) treft men beide doorboringen mediaal of juist vóór de aanhechtingsplaats der suprarostrali a an de cornua aan, die hier zooals bij de meeste Anuren divergeeren. Het zal door een vergelijking der figuren 21 a en d duidelijk zijn, dat men den toestand bij Alytes van dien van Rana af kan leiden, door den afstand tusschen

1) Vgl. fig. 21a, Pl. III, waar de suprarostralia van Rana fusca naar een figuur van Peeters afgebeeld zijn.

2) Het bloedvat vult de geheele opening, waarvan de doorsnede in afmeting overeenkomt met die van één kraakbeencel. 
de aanhechtingsplaatsen der suprarostralia sterk verkort te denken. Hiertoe geven de bij Alytes nagenoeg parallel loopende cornua alle recht. Het lijkt mij niet onmogelijk, dat ook het atrophieeren van het distale deel van het rechter bloedvat hiermede verband zou kunnen holden, daar door de geringe divergentie der beide rami palatini het mogeiijk werd, dat een van beide de functie der bloedverzorging van het betrokken huidgedeelte overnam. De tcestand, zooals Alytes dien te zien geeft, mag men dus zeker $\mathrm{riet}$ primitief noemen.

Is dus het intertrabeculaire deel van $h \geq t$ middenstuk sterk verkort, het vleugeldeel is bij Alytes veel starker ontwikkeld en gespecialiseerd dan bij Rana. Tengevolge van de vergrcoting van dezen vleugel ontstaat de groote inham, die slijkens Parker's fig 2. en 3. PI. 22 (1881) bij Calyptocephalvs Gayi ') eveneens te vinden is. Ja zelfs bestaat er mogelijkheid, dat dit deel een zekere zelfstandigheid verkrijgt ten aanzien van het middenstuk \%). Indien Parker's waarnemingen juist zijn, vindt men lit bij Cyclorhamphus culeus, Bufo lentiginosus en zeer sterk bij Cystignathus (Leptodactylus. ocellatus(?). Uit de beschrijving en afbeeldingen van Dugès (1834) en Schulze (1892) moet men wel aannemen, dat ook bij Pelobates het gedeelte (adrostrale, Dugès), waaraan het ligament, dat zich met het Meckel's kraakbeen verbindt, insercert, een zekere zelfstandigheid bezit "). Dugès noemt het een "appendice" van het suprarostrale, het bezit een "mobilité assez consédirable" t:ie Dugès, ng. 85, 86 en Pl. XIII, fig. 71 en 73!. Schulze (1892. pg. 7) noemt het adrostrale cen klein kegelvorming kraakbeenstukje, dat ,mit der querabgestutztea Basis auf dem erwähnten Vorsprung des Suprarostrale beweglich aufsitzt".

In verband met her zelfstandig kraakbeencentrum in het vleugel-

1) Vgl. fig. 21 c, PI. III, waar cen afbeelding naar Parker's figuur ontworpen werd.

2) Vgl. hiervoor fig. 21, Pl. III, waar van de hierna te noemen vormen de suprarostralia afgebecld zijn.

3. De anhechting van het ligamentum mandibulo-suprarostrale (Schulze) aan het adrostrale, laat zich vergelijken met de aanhechting van genoemd ligament bij Alytes aan het dorsale deel van de "leugelvork. 
deel, dat bij Alytes en andere Anuren het eerst verschijnt ${ }^{1}$ ), zou het niet onmogelijk zijn, dat de meerdere of mindere zelfstandigheid der laterale kraakbeenstukjes bij genoemde vormen voor primitief gehouden mag worden. Men zou dan den toestand bij Rana, wat het vleugelgedeelte betreft, door reductie van dien van Alytes kunnen afleiden. Een nader onderzoek, waarbij de aanhechting van spieren en ligamenten van belang kan zijn, is met het oog op de onbetrouwbaarheid van Parker's gegevens gewenscht en zal moeten uitmaken in welke richting het ontwikkelingsproces verloopen is. Want behalve de genoemde mogelijkheid der versmelting van een oorspronkelijk zelfstandig vleugeldeel en reductie is ook omgekeerd een specialisatie als typische aanpassing aan de eischen van den larvalen zuigmond even goed mogelijk.

\section{F. PALATOQUADRATUM, CARTILAGO MECKELI, INFRAROSTRALIA.}

\section{Stadium II.}

Er is geen kraakbeenige verbinding tusschen palatoquadratum en oorkapsel, daar een processus oticus in eigenlijken zin ontbreekt Het caudale palatoquadratum-einde legt zicht naast het reeds een weinig als crista parotica verdikte deel van den oorkapselwand ter hoogte van de ampulle van den canalis semicircularis lat. en blijft er door cen smalle bindweefselstrook van gescheiden terwijl de raakvlakken wederkeerig cenigszins afgeplat zijn. Lateraal ligt tegen dit deel van het palatoquadratum de thymus.

De verbinding van het palatoquadratum door middel van den processus ascendens met den zijwand ligt voor een deel onder het allervoorste deel van de cupula anterior. De commissura quadrato-cranialis ant. is breed en draagt een caudaal gerichten processus pseudo-pterygoïdeus, die beiderzijds doorboord is.

De processus quadratomethmoidalis zet zich in het ligamentum quadrato-ethmoïdale voort, dat zich vóór de neusholte met den processus lateralis van den trabekelhoorn verbindt.

1) Spemann (1898) onderstelt, dat het vroegtijdig verschijnen van deze laterale deelen, waaraan zich de spieren hechten, een bizondere aanpassing is. 
Aan het caudale cind van het palatoquadratum en aan den goed ontwikkelden processus muscularis ontspringen de verschillende spieren van het hyobranchiaalskelet en van het kauwtoestel 1 .

Ventraal van het palatoqutadratum vindt men den musculus perygö̈deus en den musculus depressor mandibulae posterior naast eikander gelegen. De musculus pterygoïdeis ligi mediaal en ontspringt ventraal van den processus ascendens; een deel zet zich nog sen weinig caudaal voort tot onder het oorkapsel, waaraan hij zich na de metamorphose zal hechten. De insertie geschiedt aar den rostro-lateralen bovenhoek van het Meckel's kraakbeen. De musculus depressor mandibulae post. ligt lateraal van bovengenoemde spier, ontspringt aan het deel van het palatoquadratum, dat caudaal van den processus ascendens gelegen is, en inseree:t aan den rostro-lateralen benedenhoek van het Meckel's kraakbeen. In verband met de berweging van dit skeletstuk kan men beide spieren als antagonisten beschouwen.

De musculus pierygo:̈deus verheft zich in de fenestra subocularis boven het niveaiı van het palatoquadratum en komt in éen vlak met en mediaal van den musculus temporalis te liggen; ter hoogte van den processus muscularis kruist hij deze spier ventraal en gaat over in het peesgedeelte, dat dorsaal van de pars articularis van het palatoqtadratum verloopt en zich aan het kraakbeen van Meckel hecht.

De musculus depressor mandibulae post. ligt tegen de ventrale zijde van het paiatoguadratum en wordt dorsaal door den $N$. hyomandibularis, die cen eindweegs tusschen beide ingesloten ligt, gekruist. Mediaal an den musculus depressor cartilaginis hyoideae gelegen, gaat hij terhoogte van de commisstra quadratocranialis ant. in een pees over, die juist langs het articulatiepunt van het hyoid net het palatoquadratum loopt en lateraal van den musculus depressor mandibulae ant. aan het Meckel's kraakbeen insereert. De musculus depressor mandibulae post. ondersteunt de werking van den musculus depressor mandibulac, gelijk men dien bij Ranalarven aantrelt en werd hicr in verband met zijn

1) Voor de relatieve ligging der spieren vergelijke men fig. 25 en fig. 15, Pl.IV 
functie en ligging aldus genoemd. Hij ontbreekt bij Rana en Bombinator 1:

De musculus depressor mandibulae (Rana), hier dus musculus depressor mandibulae anterior, ontspringt deels ventraal van het palatoquadratum ter hoogte van den voorrand van den processus muscularis, deels ventraal van het hyoid. Eerstgenoemd gedeelte loopt aanvankelijk dorsaal van het aan het hyoid ontspringend deel, doch spoedig vereenigen zich beide en hechten ze zich ventraal aan een klein caudo-lateraal uitsteeksel van het Meckel's kraakbeen, dat onder den voorrand van het palatoquadratum gelegen is. Het insertiepunt van den musculus depressor mandibulae post. ligt juist rostraal van dit punt.

Van het dorsale gedeelte van het palatoquadratum ontspringen de musculus temporalis en de musculus masseter.

Aan den musculus temporalis kan men rostraal twee groepen van spiervezels onderscheiden, waarvan de ventrale door Schulze (1892) bij Pelobates musculus subtemporalis genoend is. Ze ontspringen bij Alytes gezamenlijk als één spiergroep aan het caudale, naast het oorkapsel en den processus ascendens gelegen deel van het palatoquadratum, Alvorens de insertiepunten van deze beide spierbundels na te gaan, moeten hier nog twee spieren vermeld worden, die bij Alytes aan de binnenzyde van den processus muscularis afzonderlijk ontspringen en bij Rana beide den naam van musculus masseter dragen (fig. 24, pl. IV). De dorsaal gelegen spier *) vereenigt zich voor het grootste deel met den musculus subtemporalis, terwijl enkele dorsale spiervezels spoedig in pees overgaan en zich met den musculus temporalis, juist dorsaal van de aanhechtingsplaats van het paramandibulare, aan het Meckel's

1) Bij Pelobates beschrijft Schulze (1892) drie spicren, welke hẹ Meckel's kraakbeen omlaag trekken en dus den mond openen. Het meest lateraal ligt de musculus ceratohyo-angularis, vergelijkbaar met het dee! van den musculus depressor mandibulac, dat aan het hyoid ontspringt. Mediaal van dezen ligt de musculus suspensorio-angularis, ontspringend aan de onderzijde van het corpus suspensorii, onmiddellijk onder den oorsprong van den processus muscularis. Nog weer mediaal van dezen ligt de musculus quadrato-angularis, ontspringend aan de pars quadrata. Alle drie insereeren aan den angulus van de onderkaak.

2) Deze ontbreekt bij Pelobates. 
kraakbeen hechten. Van af dit punt zet zich cen deel van de pees als ligamentum mandibulo-suprarostrale (Schulze) tot aan het dorsolaterale vleugeluitsteeksel van het suprarostrale voort. Het grootste deel der vezels van de dorsaal gelegen spier vereenigt zich, zooals gezegd, met den musculus subtemporalis; ze vormen beide één enkele pees, die zich aan het ventro-laterale vleugeluitsteeksel hecht. Het schijnt me niet aanbevelenswaardig de spier, tot nu toe met dorsaal deel van den musculus masseter aangeduid, aldus te blijven noemen. Deze spier, die met het deel van den processus muscularis, waraan hij ontspringt, bijde metamorphose verdwijnen zal, is warschijnlijk een typische larvale spier, die, wat oorsprong en insertie betreft, van den ventraal gelegen eigenlijken masseter gescheiden moet worden ${ }^{1}$ ).

Deze musculus masseter ontspringt even rostraal en ventraal van bovengenoemde spier en hecht zich aan de dorsale zijde van het Meckel's kraakbeen, caudaal van den musculus pterygoïdeus.

Lateraal van den processus muscularis ontspringt de musculus depressor cartilaginis hyoideae.

De kieuwkorf is door een breede spiergroep (musculi levatores arcuum branchialium) aan den zijrand van het palatoquadratum bevestigd. Craniaal strekt de groep zich evenzoover uit als de oorsprong van den musculus temporalis, derhalve op dwarse doorsneden tot ter hoogte van het for. cranio-palatinum; caudaal yaan ze op het oorkapsel over.

Het kraakbeen van Meckel heeft de bekende transversale ligging ten opzichte van het palatoquadratum; behalve de reeds genoemde spieren hecht zich mediaal in de nabijheid van het articulatiepunt der infrarostralia de musculus submaxillaris, die niet aan een skeletstuk, maar vrij aan den lichaamswand ontspringt. Een musculus submentalis heeft zich niet (nog niet?) ontwikkeld.

Aan het kraakbeen van Meckel kan men een nagenoeg transversaal deel onderscheiden, dat met het palatoquadratum articuleert, en een onder een stompen hoek schuin naar voren gericht deel,

1) Het lijkt mij echter niet gewenscht, voor en aleer een vergelijkend onderzoek naar de larvale kauwspicren is ingesteld, deze spier reeds een definitieven naam te geven. 
waarmede de infrarostralia samenhangen. Ongeveer evenwijdig met dit laatste gedeelte loopen de admandibularia, dunne eenigszins naar beneden gerichte en verticaal geplaatste kraakbeenplaatjes, die caudaal samenhangen met het Meckel's kraakbeen, waar dit juist ventraal van de insertie van den musculus temporalis naar voren buigt 1). Het perichondrium gaat van het Meckel's kraakbeen op den dorsalen rug der admandibularia over, die derhalve genoodzaakt zijn diens bewegingen te volgen. Het distale deel der admandibularia ligt onder het epitheel van een naar binnen geslagen huidplooi.

Tusschen de admandibularia en het Meckel's kraakbeen is een lymphruimte, een voortzetting van de groote ventrale lymphruimte, gelegen en treft men den $N$. mandibularis $V$ aan, die den voor rand van het Meckel's kraakbeen volgend en er zich nauw bij aansluitend, tusschen dit en het distale deel der admandibularia naar beneden daalt en zich in takken voor de huid en den musculus submaxillaris verdeelt.

De verbinding der infratostralia met het kraakbeen van Meckel geschiedt door een eigenaardig bindweefsel, zonder dat er van een gewrichtsspleet sprake is. In de mediaan!ijn vindt men de infrarostralia. door een typisch, door bleu de Lyon donkerblauw gekleurd kraakbeenachtig weefsel, waarvan de aard later besproken zal worden, vereenigd.

Er is een zeer gering ontwikkelde copula, die juist ventraal van dit verbindingsweefsel gelegen is lengte $0,075 \mathrm{~m} . \mathrm{M}$.).

Aan de infrarostralia insereeren ventromediaal de musculigeniohyoideï, die aan de mediale zijde van ceratobranchiale IV ontspringen.

\section{Ontwikkeling.}

Het caudale einde van het palatoquadratum is niet door een processus oticus met het oorkapsel verbonden; in den loop der ontwikkeling komt het er wel in nauwe aanraking mede, zonder dat er echter kraakbeenige versmelting tusschen beide plaats vindt.

Bij de larve van het eerste stadium ligt de achterwand van het palatoquadratum in hetzelfde transversaalvlak als de voorrand

2) Vgl, voor een jonger stadium fig, 23, Pl. IV en fig. 3, PI. I. 
van de cupula anterior. Langzamerhand groeit echter het oorkapsel naar voren over den processus ascendens uit en komt het palatoquadratum ter hoogte van de ampulle van den canalis semicircularis lateralis tegen het oorkapsel te liggen. Een dunne strook kernrijk weefsel scheidt het onrkapsel van het palatoguadratum, dat caudaal in dikte toeneemt en dorsaal, ter plaatse waar de musculus temporalis ontspringt, eenigszins is uitgehold. Bij ecn larve van $25 \mathrm{~m}, \mathrm{M}$. ligt het palatoquadratum zeer dicht tegen het oorkapsel aan; later (tweede stadium) ligt het meer lateraal tegen het oorkapsel, zich aansluitend bij de crista parotica, dic zich dan gaat ontwikkelen. Tegen de metamorphose komt het caudale palatoquadratum-deel meer vrij van het oorkapsel te liggen. In totaal-preparaten, dorsaal of ventraal bezien, valt de nauwe aansluiting van palatoquadratum en oor kapsel bijzonder goed in het oog (fig. 3 en 4, Pl. I) en ziet men hoe de dorso-laterale begrenzingslijn van het corkapsel zich voortzet in de laterale grens van het palatoquadratum.

$D=$ processus quadrato-ethmoïdalis is evenals de processus pseudo-pterygoideus bij een larve van $121 ., \mathrm{m}$.M. reeds kraakbeenig. Het ligamentum quadrato-ethmoidale laat zich cerst bij een larve van $16 \mathrm{~m} . \mathrm{M}$. tot aan den processus lateralis, die blijkens vorm en kleur der kraakbeencellen nog slechts kort bestaat, vervolgen.

Meckels kraakbeen en infrarostralia ondergaan tot aan de metamorphose weinig verandering. Reeds bij een larve van $71 / 2 \mathrm{~m} . \mathrm{M}$. zijn beide kraakbeenig.

Van den aanvang af zijn de infrarostralia door een eigenaardig verbindingsweefsal verbonden, die men ook tusschen de hyoiden aantreft en daar ,pars reuniens" genoemd wordt. Het is gekenmerkt door dichte groepeering der kernen en weinig intercellulaire stof, die zich in oudere stadia met bleu de Lyon intensief blauw laat kleuren. Hierin verschilt het van het gewone kraakbeen, dat door bleu de Lyon niet gekleurd wordt. Orceine kleurt de intercellulaire stof van het verbindingsweefsel donkerbruin 1).

1) Hierdoor is het bijv. mogelijk het pars reuniens-weefsel der hyoiden electief te kleuren. De donkerbruine kleur van de intercellulaire stof van het pars reuniensweefsel steckt op doorsneden helder ai tegen het ongekleurde kraakbeen der hyoiden. 
In dit verbindingsweefsel werd voor het cerst bij een larve van $25 \mathrm{~m}$. M. caudaal en ventraal een stukje kraakbeen aangetroffen, in ligging overeenkomend met de copula II der hyoiden, die op gelijke wijze caudaal en ventraal in het pars reunicns-weefsel ligt ingeschoven. De copula tusschen de infrarostralia is op dwarse doorsnede cirkelvormig.

De kraakbeenvorming in de admandibularia vindt plaats bij larven tusschen $12 \frac{1}{2}$ en 16 m.M.

\section{LITERATUUR.}

De processus oticus ontstaat bij Rana fusca (Gaupp, 1893) als een weefselverdichting, die het achtereind van het palatoquadratum in de streek van de macula aucustica der ampulla lat. methet oorkapsel verbindt. Het kraakbeenig worden geschiedt zoowel van uit het palatoquadratum als van uit het oorkapsel zelf. Bij een larve van $23 \mathrm{~m}$.M. vindt men den processus oticus als een ronde kraakbeenige spang, die in den loop der ontwikkeling door de vorming van de crista parotica nog sterker met het oorkapsel verbonden wordt. Deze crista parotica is een product van het oorkapsel, hetgeen volgens Peeters vooral bij Rana esculenta duidelijk aan het licht treedt, waar ze ontstaat als een driehoekige uitwas tegenover het septum laterale met den top naar buiten gekeerd; ze groeit langs het oorkapsel voort en gaat ten slotte over in den processus oticus palatoquadrati. Het sterkste bewijs, dat de crista onafhankelijk van den processus oticus ontstaat, levert Alytes, daar hier geen kraakbeenige verbinding tusschen palatoquadratum en oorkapsel plaats vindt en de crista reeds bijlarven van $30 \mathrm{~m} . \mathrm{M}$. voorkomt. Met deze opvatting van Peeters kan ik mij volkomen vereenigen. Volgens Stöhr, Gaupp en Winslow komt ook bij Urodelen als Triton, Siredon, Necturus een kraakbeenige verbinding van den processus oticus met het oorkapsel tot stand, hetgeen echter door Peeters ontkend wordt.

Hoewel men bij Alytes geen processus oticus in eigenlijken zin kan onderscheiden, die zooals bij Rana met het oorkapsel vergroeit, mag men het caudo-laterale tegen het oorkapsel gelegen deei van het palatoquadratum toch wel dezen naam geven en vergelijken met 
den processus oticus der Urodelen, die zich volgens Peeters ook niet kraakbeenig met het oorkapsel verbindt. Alytes is intusschen niet de eenige vorm onder de Anuren, waarbij de processus oticus niet of zwak ontwikkeld is. Men vergelijke bijv. Parker's figuren op Pl. 22 en 30 (1881). In sommige gevallen, waar de processus oticus zwak ontwikkeld is, heeft de crista parotica groote afmetingen aangenomen en komt een vereeniging van beide toch tot stand (i'arker, P1. 17, fig. 1, 2, 5 en 6, Leptodactylus ocellatus?). Bij Alytes is de crista parotica daarentegen zwak ontwikkeld.

Het ligamentum quadrato-ethmoidale ontwikkelt zich bij Rana fusca vroegtijdig (larve $14 \mathrm{~m} . \mathrm{M}$.) en gaat aan de vorming van den processus quadrato-ethmoidalis vooraf (larve $25-30$ m.M.), in tegenstelling met Alytes, waar deze laatste het eerst verschijnt. Bij Pseudis schijnt volgens Parker dit ligament kraakbeenig te worden en met den processus lateralis van de cornu trabeculae een ovale opening te omsluiten.

De processus pseudopterygoïdeus treedt bij Rana eerst laat op, volgens Gaupp bij larven tusschen 29 m.M. en de metamorphose, volgens Peeters reeds bij een larve van $29 \mathrm{~m}$.M. Dit is bij Alyteslarven van $16 \mathrm{~m} . \mathrm{M}$. reeds het geval. De ontwikkeling van den processus pseudopterygoïdeus kan soms zeer sterk zijn (Pseudis paradoxa, Calyptocephalus gayi), soms ook ontbreken (Leptodactylus, Hyla, Nototrema, Acris e.a., Parker, 1881).

Het is hier de plaats niet om in vergelijkingen te treden omtrent de spieren, die aan het palatoquadratum ontspringen en het larvale kauwtoestel bewegen. Evenals voor de kauwspieren van het volwassen dier is een herziening der nomenclatuur zeer noodig. Door Gaupp (18931 is er reeds op gewezen, hoe het gebruik van namen, aan de menschelijke anatomie ontleend, hier slechts verwarring kan stichten ${ }^{1}$ ).

Voor Rana fusca vindt men bij Gaupp (1898) aangegeven, dat de beide infrarostralia door een uit hyalienkraakbeen bestaand copulare verbonden zijn. Bij een larve van $14 \mathrm{~m} . \mathrm{M}$. (volgens

1) Voor literatuur omtrent de larvale kauwspieren van eenige Auuren maghier verwezen worden naar Dugès (1834, Pelobates), Reichert (1838, Ranal, Götte 11575. Bombinatori, Schulze (1892, Pelobates) en Gaupp (1898. Rana). 
Peeters reeds vroeger) vindt men een verbindende weefselstrook, die spoedig in kraakbeen zal overgaan. Bij Rana esculenta vindt men dit kraakbeen reeds bij een larve van 6.5 m.M. (Peeters, 1910). Men krijgt uit de beschrijving van Gaupp niet den indruk, dat hij bij Rana fusca het kraakbeen van de copula in het verbindingsweefsel zag ontstaan en derhalve beide onderscheidt. Peeters daarentegen beschrijft de latere vorming van de copula, die beiderzijds door "zwakker" kraakbeen met de infrarostralia verbonden is. Dat Peeters hier hetzelfde eigenaardige kraakbeen op het oog heeft, dat ook bij Alytes gevonden wordt, blijkt, wanneer hij zegt (pg. 157): „door zijne kleinere overlangs gestrekte cellen en later bovendien door zijn donkerder kleur, blijft het tot na de metamorphose scherp onderscheiden van het kraakbeen der infrarostralia zelf'. Het karakter van dit kraakbeen wordt eerst recht duidelijk door de vroeger beschreven kleurmethoden met bleu de Lyon en orceïne (vgl. pg. 14). Het gedraagt zich tegenover deze kleuringen op dezelfde wijze als het pars reuniens-weefsel der hyoiden, terwijl beide in opvallend licht een geelachtige tint hebben, in tegenstelling met het witte kraakbeen der hyoiden en infrarostralia zelf.

In verband met bovenstaande reacties en de gele kleur van het weefsel is het niet onmogelijk, dat de tusschenschotten der cellen een elastine-achtige stof bevatten. Elastisch kraakbeen in den gewonen zin des woords is het niet, daar men dan in de intercellulaire stof een fijn netwerk van elastische vezels zou moeten aantreffen, hetgeen hier niet het geval is ${ }^{1}$ ).

In hoeverre de copula der infrarostralia vergeleken mag worden

1) De meeningen omtrent den aard van het pars reuniens-weefsel der hyoiden zijn verdeeld. Stöhr (1882) heeft dit het eerst beschreven en voor kraakbeen fehouden. Gaupp (1893 en 1906) hield het voor jong, niet uitgegroeid kraakbeen. Ridewood (1898) spreekt van "a dense mass of whitish fibrous tusstie"; bij Microhyla ornata maakt het op hem werkelijk den indruk van kraakbeen.

Dat het inderdaad ook kraakbeen is, al is het ook van een bizondere soort, is na het boven gezegde duidelijk. In verband met de bewegingen, die de hyoiden door de contractie van den musculus subhyoideus maken, is een dergeijike sívige en tegelijk bewegelijke verbinding zeer begrijpelijk. 
met het ongepaarde kraakbeenstukje, dat bij Xenopus de beide cartilagines Meckeli verbindt, zolt de ontwikkelingsgeschiedenis bij dezen vorm moeten uitmaken. Ridewood (1898), die ditkraakbeentje bij Xenopus met den naam van basimandibulare bestempelt, vergelijkt het met het basihyale en beschouwt het als een primitieve toestand, waarvan de gepaarde infrarostralia door deeling af te leiden zijn. Wanneer dus Gaupp (1906) de copula met het basimandibulare van Xenopus vergelijkt, volgt hij hierbij niet den gedachtengang van Ridewood, want dan rijst de vraag, waarmee de infrarostralia zelf vergeleken moeten worden. Parker (1876) beeldt bij Xenopus in verschillende stadia steeds twee infrarostralia af en spreekt (pg. 630) van ,the interposition of a pair of short, terete, inferior labials". Waarschijnlijk is deze opgave van Parker niet juist ${ }^{1}$ ). Ik zelf vond bij cen Xenopus-larve (vóor de metamorphose, $67 \% \mathrm{~m} . \mathrm{M}$. lang, achterpooten $5 \mathrm{~m} . \mathrm{M}$.) een ongepaard transversaal liggend, gebogin kraakbeenstukje, dat m. i., naar den vorm te oordeelen, de beide infrarostralia en niet de copula van Rana en Alytes vertegenwoordigt.

Wanneer men bij Anuren als Rana, Alytes e. a. in het geheel geen copula aantrof, zou de hypothese van Ridewood aan waarschijnlijkheid winnen. $\mathrm{Nu}$ dit wel het geval is, lijkt mij de veronderstelling, dat de infrarostralia als afgesnoerde deelen van het Meckel's kraakbeen te beschouwen zijn en de copula vergeleken mag worden met het basihyale, gelijk Gaupp (1893, reeds deed, het meest voor de hand liggende.

Bij Pipa komt volgens Parker (1876) geen copula voor en ontbreken de infrarostralia. Hetzelfde geldt voor Urodelen. Dat de aanwezigheid der inírarostralia verband houdt met het larvale leven, speciaal met den zuigmond der Anuren, mag wel aangenomen worden.

1) Het kan ook zijn, dat in jonge stadia bij Xenopus de infrarostralia gescheiden aangelegd worden en later vergroeien, 


\section{Overzicht der verkregen uitkomsten.}

De uitkomsten, waartoe het onderzoek naar de ontwikkeling van het chondrocranium van Alytes obstetricans geleid heeft, kunnen als volgt samengevat worden :

1. De kop der Anuren omvat een segment minder dan die der Urodelen. In verband hiermede is het zeer waarschijnlijk, dat de basaalplaat slechts uit twee componenten is samengesteld: de trabekelplaat en de occipitaalplaat. Het feit, dat bij Anuren, in tegenstelling met Urodelen, het mesotisch kraakbeen nooit is aangetoond en zich niet laat omschrijven, geeft aan deze opvatting steun.

Bij Alytes gaan beide componenten gelijktijdig in kraakbeen over, zoodat het niet als bij Rana (''eeters, 1910) mogelijk is een afzonderlijke basis van den occipitaalboog aan te toonen.

2. De basaalplaat laat zich van het oorkapselkraakbeen afgrenzen en neemt geen deel aan de vorming van den medialen rand van het primaire ovale venster.

3. In verband met de ligging ten opzichte der segmenten is het zeer waarschijnlijk, dat de occipitaalboog der Anuren gelijkwaardig is met den praeoccipitaalboog der Urodelen en bij gevolg de atlas der Anuren homoloog met den occipitaalboog der Urodelen.

4. De ontwikkeling van den occipitaalboog geschiedt, in tegenstelling met Rana fusca, vóór die van den eersten wervel.

5. De occipitaalboog ontwikkelt zich gedeeltelijk in aansluiting bij de basaalplaat, gedeeltelijk van uit het tegen het oorkapsel gelegen deel.

6. De crista occipitalis lateralis ontbreekt in jonge stadia aanvankelijk, doch ontwikkelt zich ten slotte evenzeer als bij Rana. 
7. De chorda dorsalis strekt zich door zeer vroegtijdige reductie niet tot het infundibulum uit. Er blijft een groote ruimte tusschen beide, die zich in den loop der ontwikkeling verkort, maar niet verdwijnt. Tengevolge hiervan wordt het planum trabeculare terstond ook vóór de chordapunt aangelegd en kan de kraakbeenvorming aldaar plaats vinden, zonder dat er in de alleruiterste chordapunt reductieverschijnselen behoeven op te treden.

8. De reductie van de chorda geschiedt in drie gedeelten, waarbij het proces der samenvouwing van het voorste stuk en dat der dorsale en ventrale overgroeiing als bij Rana fusca vóór de metamorphose verloopen.

9. Het eerste kraakbeen in het oorkapsel wordt niet als gewoonlijk om het laterale boogkanaal aangetroffen, maar ontwikkelt zich van uit twee punten: de cupula anterior en de cupula posterior. Van uit het eerste punt zet het kraakbeen zich in caudale richting om den canalis semicircularis lat. voort; van uit het tweede punt wordt het gehoororgaan medio-ventraal overgroeid en vindt de versmelting met de basaalplaat plaats.

10. Van den medialen oorkapselwand ontwikkelt zich het gedeelte caudaal van het for. acusticum het eerst.

11. Het for. acusticum wordt secundair in een for. acusticum ant. en post. gedeeld door een tusschenschot, dat niet in hetzelfde vlak als de mediale oorkapselwand ligt, maar meer binnenwaarts uit het oorkapsel zelf oprijst.

12. Er bestaat verband tusschen de ontwikkeling van den recessus partis basilaris en het al of niet aanwezig zijn van een for. perilymphaticum externum. Bij Urodelen en onder de Anuren bij Pipa (en Xenopus?) is deze recessus zeer weinig of niet ontwikkeld en treft men alleen het for. perilymphaticum int. aan; bij Anura Phaneroglossa als Rana, Alytes e. a. is hij larvaal terstond goed ontwikkeld en wordt de externe opening in den oorkapselwand uitgespaard.

Het for. perilyphaticum int. is het phylogenetisch oudere.

De beide for. perilymphatica zijn gepraeformeerde openingen en niet als het for. perilymphaticum ant. en post. bij Hynobius door deeling van een in den medialen oorkapselwand gelegen opening ontstaan. 
13. Een for. perilymphaticum accessorium ontbreekt bij Alytes.

14. De nervus facialis betreedt met den nervus acusticus ant. het oorkapsel en doorboort den medio-ventralen oorkapselwand. Secundair wordt deze zenuw in een kanaal ingesloten, waarvan het allervoorste, extra-capsulaire deel door basaalplaat en oorkapselwand gevormd wordt en het grootste, intra-capsulaire deel door overgroeiing binnen het oorkapsel ontstaat.

15. De canalis semicircularis posterior wordt het laatst door een kraakbeenig septum van de oorkapselruimte gescheiden. Dat dit septum in de phylogenie het laatst opgetreden is, wordt behalve door dit late ontstaan ook waarschijnlijk gemaakt door het feit, dat het bij enkele Urodelen individueel of constant kan ontbreken en het vliezige achterste boogkanaal zich in de ontogenie het laatst afzondert.

16. Vóór de metamorphose komt er geen kraakbeenige vereeniging van palatoquadratum en oorkapsel door middel van een processus oticus tot stand. Hoewel het caudale eind van het palatoquadratum zich zeer nauw tegen het oorkapsel aanlegt, blijft het er steeds door een zeer dunne weefselstrook van gescheiden.

17. De crista parotica is vóór de metamorphose slechts zwak ontwikkeld.

18. Het tectum posterius is bij Anuren waarschijnlijkeen tectum synoticum, aan welks vorming de occipitaalboog niet deelneemt in tegenstelling met Urodelen, waar het als tectum interoccipitale beschouwd mag worden.

19. Een taenia tecti medialis ontbreekt.

20. Vrije taeniae tecti marginales worden bij Alytes niet aangetroffen; hetgeen daaraan beantwoordt ontving daarom den naam ván cristae marginales.

21. Het eerste kraakbeen van het operculum wordt in den caudalen benedenhoek van het ovale venster aangetroffen. Er zijn redenen om aan te nemen, dat het operculum een deel is van den oorkapselwand en in de phylogenie later optrad dan de columella (pars interna plectri), die in verband met de onderzoekingen van Kingsbury en Reed en Marcus zeer waarschijnlijk van den hyoidboog afgeleid mag worden.

22. Het operculum der Anura Phaneroglossa wordt in tegen- 
stelling met het operculum (pars opercularis) der Urodelen vóór het plectrum kraakbeenig. Bij de Anura Aglossa (Pipa en Xenopus) is dit niet het geval en ontbreekt een vrij operculum ook larvaal. Het is evenwel mogelijk, dat bij nader onderzoek blijken zal, dat een pars opercularis aan het gehoorbeentje der Aglossa onderscheiden mag worden.

23. De chondrificatie en waarschijnlijk ook de aanleg der trabeculae wordt in tegenstelling met Rana van achteren naar voren duidelijken, naar vrij zeker aan te nemen is, in aanshiting bij de parachordaalplaat.

24. De zijwand ontwikkelt zich vroegtijdig als een vrij breede, laterale wandlijst in rostrale richting in aansluiting bij den zijwandpijler. Deze laterale kraakbeenstrook, die men bezwaarlijk als bij Rana „dorsale Randspange” noemen kan, verbindt zich met het opwaarts groeiend deel van de trabekel ter hoogte van de commissura quadrato-cranialis anterior.

25. In tegenstelling met Rana wordt het for. N. oculomotorii niet terstond, vóór de verdere ontwikkeling van het zijwandkraakbeen, nauw omgrensd, maar eerst veel later, tegen de metamorphose. Het scheidingswandje, dat zich tusschen het for. N. II en III waarschijnlijk van uit de laterale wandlijst èn de trabekel ontwikkelt, groeit hiertoe in caudale richting voort.

26. Van uit de laterale wandlijst groeit het kraakbeen omhoog en wordt de hersenholte ook dorso-lateraal begrensd.

27. Vóór het foramen $\mathbf{N}$. trochlearis is in den kraakbeenigen zijwand een opening gelegen, waardoor een takje van de vena jugularis de hersenholte betreedt. Deze opening verdwijnt met de metamorphose.

28. Het foramen $N$. trochlearis kan bij larven in de metamorphose behalve in den kraakbeenigen zijwand ook in het fronto-parietale aangetroffen worden.

29. De bodemvorming geschiedt in aansluiting bij het planum internasale, dat in tegenstelling met Rana eerst na het kraakbeenig worden van het planum trabecularc ontstaat, in caudale richting en ook in mediale richting in ansluiting bij de trabekels. Het for. caroticum wordt vóór het for. cranio-palatinum kraakbeenig omsloten; het gedeelte onder de hypophyse gaat het laatst, doch vóór de metamorphose in kraakbeen over. 


\section{De bodemvorming vertoont somtijds variaties.}

30. De vorming van het for. proöticum geschiedt door de kraakbeenige verbinding van den zijwand met het oorkapsel. Deze kraakbeenbrug zet zich in de cristae marginales voort en is eerst na de kraakbeenontwikkeling in den zijwand aanwezig.

31. De praecerebraalplaat bezit geen fenestra praecerebralis en ontwikkelt zich dee!s van uit de internasaalplaat, deels van uit de kraakbeenruggen op de cornua.

32. De canalis pro R. interno narium $V$ wordt door zijwand en processus antorbitalis begrensd, terwijl het dak zelfstandig in kraakbeen overgaat.

33. De cornua trabeculae groeien in den loop der ontwikkeling naar voren uit en zijn nagenoeg parallel. Ze zijn zijdelings in cen processus lateralis verbreed, die bij Rana fusca ontbreekt, doch bij talrijke Anuren eveneens voorkomt cn waaraan zich het ligamentum quadrato-ethmoïdale hecht.

34. Ventraal zijn de hoorns voor een deel door een stevigen kraakbeenband (het homologon van het ligamentum intertrabeculare inf. van Rana) verbonden; dit verbindingskraakbeen zet zich rostraal in een ligament voort, dat zich na splitsing aan de cornua einden hecht. Ook dorsaal worden de hoorns over een korten afstand kraakbeenig verbonden.

Een ligamentum intertrabeculare sup. treft men aan de cornuaeinden aan; het zet zich lateraal over de suprarostralia voort.

35. De aanleg der suprarostralia wordt, in tegenstelling met Rana, eerst nà dien van de trabekels zichtbaar en sluit bij den cornua-aanleg aan. Later worden de suprarostralia door een met bleu de Lyon blauw te kleuren weefselstrookje van de cornua gescheiden.

36. De suprarostralia zijn in aanleg niet gescheiden. De kraakbeenvorming vindt van uit een lateraal gelegen centrum en van uit het bij de cornua aansluitend deel plaats, terwijl het middenstuk het laatst in kraakbeen overgaat.

37. Op grond van de mediane ligging van den alleen rechts tot aan het middenstuk der suprarostralia te vervolgen ramus palatinus der arteria carotis, laten zich de suprarostralia van Rana fusca niet op de door Peeters aangegeven wijze van die van 
Alytes afleiden. De toestand bij Alytes dankt zijn ontstaan aan het weinig of niet divergeeren der cornua en als gevolg daarvan de sterke verkorting van het middengedeelte der suprarostralia.

38. Het groote vleugeldeel van Alytes is of aan sterke specialisatie toe te schrijven en heeft zich dan uit het kleine overeenkomstige stuk bij Rana ontwikkeld, of dankt zijn ontstaan aan de versmelting van het al of niet gepaarde middenstuk, dat van den trabekelhoorn af te leiden is, met een vrij lateraal kraakbeenstuk, zooals bij sommige Anuren door Parker gevonden werd. In dit laatste geval is de toestand bij Rana door reductie van den vleugel van Alytes ontstaan te denken. Voor deze tweedehypothese pleit het eerst kraakbeenig worden van 't laterale kraakbeen der suprarostralia.

39. Het palatoquadratum gaat in rostrale richting in kraakbeen over en bezit geen goed ontwikkelden processus oticus, die het met het oorkapsel verbindt.

40. De processus pseudo-pterygoïdeus vertoont in oudere stadia een doorboring.

41. Het ligamentum quadrato-ethmoïdale ontwikkelt zich na den processus quadrato-ethmoïdalis.

42. Bij Alytes wordt, behalve de bij Rana eveneens voorkomende musculus depressor mandibulae, een aan het caudale deel van het palatoquadratum ontspringende spier aangetroffen, die hier in verband met functie en ligging musculus depressor mandibulae posterior genoemd werd. De rostraal gelegen spiergroep draagt bijgevolg den naam van musculus depressor mandibulae anterior.

43. Aan de binnenzijde van den processus muscularis ontspringt dorsaal van den musculus masseter een zelfstandige spier, die een eigen insertiepunt aan het kraakbeen van Meckel en het suprarostrale heeft. Een vergelijkend onderzoek moet uitmaken of deze spier tot den musculus masseter gerekend mag worden.

44. Aan het kraakbeen van Meckel hechten zich, behalve de genoende spier en de musculus masseter, de musculus pterygoïdeus, de beide deelen van den musculus temporalis en het ligamentum mandibulo-suprarostrale.

45. De admandibularia (paramandibularia, Peeters) liggen, ook in aanleg, tegen het kraakbeen van Meckel aan en zijn er later door perichondrium mede verbonden. 
46. De infrarostralia, in aanleg met het Meckel's kraakbeen één, zijn door een verbindingsweefsel verbonden, dat dezelfde eigen schappen vertoont als het pars reuniensweefsel der hyoiden. Bleu de Lyon kleurt het intensief blauw, orceine donkerbruin, terwijl het kraakbeen ongekleurd blijft. Op grond van deze kleurreacties, die ook geschikt zijn om elastische vezels aan te toonen en op grond van den bouw en het uiterlijk van dit weefsel (geel, tegenover het witte kraakbeen) mag men aannemen, dat dit verbindingsweefsel een eigenaardig soort kraakbeen is, waarvan de intercellulaire tusschenschotten een elastine-achtige stof bevatten.

47. Bij oudere larven treedt in dit verbindingsweefsel een normaal kraakbeenige copula op, die waarschijnlijk niet met het ongepaarde kraakbeenstuk, dat bij Xenopus de mandibulae verbindt, vergeleken mag worden. De copula der Anura Phaneroglossa komt in ligging overeen met het basihyale, dat de hyoiden verbindt.

Het onderzoek naar de ontwikkeling van het chondrocranium van Alytes obstetricans heeft naast vele punten van overeenkomst ook meer of minder belangrijke verschillen met Rana fusca, dieals best onderzochte. vorm hier in de eerste plaats genoemd mag worden, naar voren gebracht. Vele van deze afwijkingen hangen met de snelle ontwikkeling van het caudale of den vertraagden aanleg van het rostrale schedeldeel samen. Als zoodanig kunnen genoemd worden: het gelijktijdig kraakbeenig worden van de beide componenten van de basaalplaat, de ontwikkeling van den occipitaal boog vóór den eersten wervel en in verband hiermede het aanvankelijk ontbreken van de crista occipitalis lat., de chondrificatie der trabeculae van achteren naar voren, de vorming van het planum internasale na die van het ongepaard planum trabeculare, de snelle ontwikkeling van de laterale wandlijst vóór de omgrenzing van het for. $N$. oculomotorii en het for.proöticum en de late en ongepaarde aanleg der suprarostralia ${ }^{1}$ ). De kraakbeenontwikkeling bij Alytes verloopt dus in het algemeen in tegenstelling met Rana in rostrale richting.

Naast enkele kenmerken, die op hooger specialisatie wijzen,

1) De vroegtijdige reductie van de uiterste chordapunt kan ook als het gevolg van een versnelden ontwikkelingsgang beschouwd worden. 
zooals het gevorkte vleugeldeel der suprarostralia en het voorkomen van een grooter aantal spieren 1), vindt men afwijkingen, die haar oorzaak vinden in de reductie van den kraakbeenschedel en als gevolg daarvan aansluiten bij hetgeen de chondrocrania der Urodelen te zien geven, zonder daarom nog primitief te zijn. Immers Gaupp heeft er reeds op gewezen, dat het Anurenchondrocranium door zijn rijker kraakbeenontwikkeling in sommige opzichten primitiever is dan dat der Urodelen. Bij Alytes treft in dit verband het ontbreken van een taenia tecti medialis; en waarschijnlijk mag hierbij ook het gemis van den processus oticus gerekend worden.

Er zijn echter een tweetal punten, waarin Alytes zich primitiever toont dan Rana. Het feit, dat de N. facialis met de gehoorzenuw het oorkapsel betreedt, een toestand, dien men ook bij vele Urodelen aantreft, is in verband met de nauwe betrekking, die oorspronkelijk tusschen beide zenuwen bestond en den overeenkomstigen loop bij Petromyzon als zoodanig op te vatten. Ook het voorkomen van admandibularia, die aan de lipkraakbeentjes der Selachii of de paramandibularia der Dipnoi herinneren, is aldus te beschouwen.

Twee kenmerken, die tot nu toe als typisch voor Urodelen golden, blijken ook bij Anuren te kunnen voorkomen: het facialisverloop binnen het oorkapel en het doorboren der fronto-parietalia door den $\mathrm{N}$. trochlearis.

Omgekeerd blijken twee typische Anuren-kenmerken : het voorkomen van twee foramina perilymphatica en het verschijnen van het operculum vóór de pars interna plectri, onder de Anura Aglossa bij Pipa, niet aanwezig te zijn; deze sluit zich in dit opzicht nauwer de Urodelen aan dan bij de Anura Phaneroglossa.

1) Behalve de musculus depressor mandibulac post. kan de door Pecters (1910) voor het eerst beschreven musculus infrabranchialis van het hyobranchiaalskelet worden genoemd. 


\section{Literatuur.}

1897 B ergfeldt, A. Chordascheiden und Hypochorda bei Alytes obstetricans. Anatomische Hefte. 1e Abt., Bd. 7.

1876 Born, G. Ueber die Nasenhöhlen und den Thränennasengang der Amphibien. Morphol. Jahrb. Bd. II.

1901 Buchs, G. Uleber den Ursprung des Kopfskeletes bei Necturus. Morph. Jahrb. Bd. XXIX.

1891 Chiarugi, G. Sur les myotomes et sur les nerfs de la tête postérieure et de la région proximale du tronc dans les embryons des Amphibiens anoures. Archives italiennes de biologie. Tome XV.

1902 Coghill, G. E. The cranial nerves of Amblystoma tigrinum. The Journal of comp. Neurology. Vol. 12.

1888 Cope, E. D. On the relations of the hyoid and otic elements of the skeleton in the Batrachia. Journal of Morphology. Vol. II.

1917 Delsman, H. C. Korte Geschiedenis van den kop der gewervelde dieren. Verslag van de Gewone Vergadering der Wis en Natuurkundige Afd. der Kon. Academie van Wetenschappen. DI. XXVI.

1900 Drüner, L. Ueber Mikrostereoskopie und eine neue vergrössernde Stereoskopcamera. Zeitschrift für Wiss. Mikroskopie und für Mikr. Technik. Bd. 17.

1834 Dugès, A. Recherches sur l'ostéologie et la myologie des Batraciens à leurs differens ages. Paris.

1910 Eycleshymer, A. C. and J. M. Wilson. Normal plates of the Development of Necturus maculosus. Normentafeln zur Entwickelungsgeschichte der Wirbeltiere. Herausgegeben von Prof. Dr. F. Keibel. 
1907 Fuchs, H. Ueber die Entwickelung des Operculums der Urodelen. Anat. Anzeiger. Ergänzungsheft zum XXX Bd. 1904 F ürbringer, K. Beiträge zur Morphologie des Skeletts der Dipnoer nebst Bemerkungen über Pleuracanthiden, Holocephalen und Squaliden. Jenaische Denkschr. Bd. IV.

1. Teil. (Semon, Zoöl. Forschungsreise in Australien I).

1918 Gaay Fortman, J. P. de, Die Entwicklung der Wirbelsäule von Megalobatrachus maximus und einiger anderen Amphibien. Tijdschrift der Ned. Dierk. Ver. (2). DI. XVI.

1893 Gaupp. E. Beiträge zur Morphologie des Schädels. I. Primordialcranium und Kieferbogen von Rana fusca. Morph. Arbeiten G. Schwalbe. Bd. II.

1898 - Ontogenese und Phylogenese des schalleitenden Apparates bei den Wirbeltieren. Ergebnisse der Anatomie und Entwickelungsgeschichte. Bd. VIII.

1906 - Die Entwickelung des Kopfskelettes. Handbuch der vergleichenden und experimentellen Entwickelungslehre der Wirbeltiere. Bd. III.

1911 - Ueber den N. trochlearis der Urodelen und über die Austrittsstellen der Gehirnnerven aus dem Schädelraum im allgemeinen. Anat. Anzeiger. Bd. XXXVIII.

1875 Goette, A. Die Entwickelungsgeschichte der Unke (Bombinator igneus) mit Atlas. Leipzig.

1911 Goodrich, E. S. On the occipital region of the head in the Batrachia urodela. Proceedings of the Zoöl. Society of London.

$1902 \mathrm{H}$ arrison, H. S. On the Perilymphatic Spaces of the Amphibian Ear. Internationale Monatschrift für Anat. und Phys. Bd. 19.

$1873 \mathrm{H}$ asse, C. Die Lymphbanen des inneren Ohres der Wirbeltiere. Anatomische Studien, herausgeg. von C. Hasse. Leipzig.

1889 Heron-Royer et van Bambeke. La vestibule de la bouche chez les têtards Batraciens Anoures d'Europe etc. Archives de biologie. Tome IX.

1893 Howes, G. B. Notes on Variation and Development of 
the vertebral and Limbskeleton of the Amphibia. Proceedings of the Zooll. Society of London.

1880 I h e r in g. H. v. Ueber die Wirbelsäule von Pipa. Morphol. Jahrb. Bd. VI.

1901 Kallius, E. Beiträge zur Entwickelung der Zunge. Anatomische Hefte. Bd. XVI.

$1873 \mathrm{Ket}$ e 1, H. Ueber das Gehörorgan der Cyclostomen. Anatomische Studien, herausgegeben von C. Hasse. Leipzig. $1909 \mathrm{~K}$ ings bury, B. F. and H. Reed. The columella auris in Amphibia. Journal of Morphology. Vol. 20.

1910 Kothe, K. Entwickelungsgeschichtliche Untersuchungen über das Zungenbein und die Ohrknöchelchen der Anuren. Archiv für Naturgeschichte. 76. Jhrg. Bd. 1. Heft 1.

1910a Marcus, H. Beiträge zur Kenntnis der Gymnophionen, III. Morphol. Jahrb. Bd. XL.

1910 b - Beiträge zur Kenntnis der Gymnophionen, IV. Festschrift Richard Hertwig. Jena.

1904 Noordenbos. W. Over de ontwikkeling van het chondrocranium van Zoogdieren. Diss. Groningen.

1906 Okajima, K. Zur Anatomie des inneren Gehörorgans von Cryptobranchus japonicus. Anatomische Hefte. Bd. XXXII.

1911 a - Beiträge zur Kenntnis der knorpeligen und knöchernen halbzirkelförmigen Kanäle bei Urodelen. Anat. Anzeiger. Bd. XXXVIII.

1911 b - Ueber das Vorkommen von zwei Foramina perilymphatica beim Urodelenohr. Anat. Anzeiger. Bd. XXXVIII.

1912 - Die Entwickelung des Gehörorgans von Hynobius. Anat. Hefte. 1. Abt. Bd. XLV.

1902 Osawa, G. Beiträge zur Anatomie des japanischen Riesensalamanders. Mitteilungen aus der medizinischen Fakultät der Kais. Japan. Univ, zu Tokio. Bd. V.

1871 Parker, W. K. On the structure and development of the skull of the common Frog (Rana temporaria). Part I. Philosophical Transactions of the Royal Society of London. Vol. CLXI.

1876 - On the structure and development of the skull in the 
Batrachia, Part II. Philosophical Transactions of the Royal Society of London. Vol. CLXVI.

1881 - On the structure and development of the skull in the Batrachia. Part III. Ibidem. Vol. CLXXII.

1910 Peeters, J. L. E. Over de ontwikkeling van het chondrocranium en de kraakbeenige wervelkolom van eenige Urodela en Anura. Diss. Leiden.

1898 Peter, K. Die Entwickelung und funktionalle Gestaltung des Schädels von Ichtyophis glutinosus. Morphol. Jahrb. Bd. XXV.

1897 Platt, J. B. The development of the cartilaginous s'cull and of the branchial and hypoglossal musculature in Necturus. Morphol. Jahrb. Bd. XXV,

1832 Rathke, H. Anatomisch-philosophische Untersuchungen über den Kiemenapparat und das Zungenbein der Wirbeltiere. Riga und Dorpat.

1913 Reed. H. D. The sound-transmission apparatus in Necturus. Anat. Record. Vol. IX.

1838 Reichert, C. B. Vergleichende Entwickelungsgeschichte des Kopfes der nackten Amphibien, etc. Königsberg.

1897 Ridewood. W. G. On the development of the vertebral column in Pipa and Xenopus. Anat. Anzeiger. Bd. XIII.

$1898 \mathrm{a}$ - On the development of the hyobranchial skeleton of the midwife-toad (Alytes obstetricans). Proceedings of the Zoöl. Society of London.

$1898 \mathrm{~b}$ - On the structure and development of the hyobranchial skeleton and larynx in Xenopus and Pipa, with remarks on the affinities of the Aglossa. The Journal of the Linnean Society. Vol. XXVI.

1892 Schulze, F. E. Ueber die inneren Kiemen der Batrachierlarven. Abhandlungen der Königl. Akademie der Wissenschaften zu Berlin.

1895 Sewertzofl, A. Die Entwickelung der Occipitalregion der niederen Vertebraten in Zusammenhang mit der Frage über die Metamerie des Koptes. Bulletin de la Société impériale des Naturalistes de Moscou. No. 2.

1907 Sonies, F. Ueber die Entwickelung des Chondrocraniums 
und der knorpeligen Wirbelsäule bei den Vögeln. Petrus Camper. Dl. IV.

$1898 \mathrm{Spem}$ ann. H. Ueber die erste Entwickelung der Tuba Eustachii und des Kopfskelets von Rana temporaria. Zoöl. Jahrb., Abt. für Anatomie und Ontogenie der Tiere. Pd. XI. $1880 \mathrm{St}$ öhr, Ph. Zur Entwickelungsgeschichte des Urodelenschädels. Zeitschrift für Wiss. Zoölogie. Bd. XXXIII.

1882 - Zur Entwickelungsgeschichte des Anurenschädels. Ibidem. Bd. XXXVI.

$1842 \mathrm{~V} \circ \mathrm{gt}, \mathrm{C}$. Untersuchungen über die Entwickelunsgeschichte der Geburtshelferkröte.

1877 W i e ders he i m. R. Das Kopískelett der Urodelen. Morph. Jahrb. Bd. III.

$1898 \mathrm{~W}$ in s lo w, G. M. The chondrocranium in the Ichthyopsida. Tuft's College Studies. No. 5.

1896 Witebsky. M. Die Entwickelungsgeschichte des schallleitenden Apparates des Axolotl (Siredon pisciformis). Inaug. Diss. Berlin. 


\title{
Verklaring der figuren. $\left.{ }^{1}\right)$
}

\author{
PLAAT I.
}

Fig. 1. Chondrocranium van een larve van 7 m.M. (serie 9). Naar een wasmodel. Van de dorsale zijde gezien. Vergrooting $50 \times$.

Rechts is het zijwandkraakbeen niet afgebeeld. De suprarostralia en een deel van den occipitaalboog zijn nog voorkraakbeenig en door een lichtere kleur aangegeven. De grens tusschen oorkapsel en basaalplaat is gestippeld. N. $V_{1}$ en $V_{2}$ werden niet aangegeven. * Het mediane, niet duidelijk afgegrensde verbindingsweefsel tusschen de suprarostralia. ${ }^{\star \star}$ Niet kraakbeenig verbindingsweefsel tusschen de infrarostralia. $\star \star \star$ Voorkraakbeenig weefsel dorsaal van de chorda.

Fig. 2. Hetzelfde chondrocranium van de ventrale zijde gezien. Vergrooting $50 \times$. De admandibularia zijn nog voorkraakbeenig en niet aangegeven.

Fig. 3. Chondocranium van een larve van $32 \mathrm{~m} . \mathrm{M}$. totale lengte: achterpootlengte $3 \mathrm{~m} . \mathrm{M}$. Naar een totaalpreparaat (fixatie: pikrine-zwavelzuur: kleuring: methyleenblauw). Van de dorsale zijde gezien. Vergrooting $16 \times$.

Door het wegprepareeren der hersenen was het niet mogelijk na te gaan hoever het middengedeelte van de taenia tecti transversalis ontwikkeld was. Het licht gekleurde deel van den schedelbodem is nog zeer jong

1) Alle figuren hebben betrekking op Alytes obstetricans, behalve schema 2 en fig. 16. 
kraakbeen. Het kraakbeen van Meckel, de infrarostralia en de admandibularia zijn duidelijkheidshalve weggelaten.

Fig. 4. Hetzelfde chondrocranium van de ventrale zijde gezien. Vergrooting $16 \times$.

Het ovale venster en het for. perilymphaticum ext. zijn niet aangegeven, daar deze zich door de sterke kleuring van het norkapsel aan de waarneming onttrokken. * Plaats, waar de $\mathrm{N}$. facialis uit het oorkapsel te voorschijn treedt.

Door een retouche-fout is de ligging van den proc. pseudo-pterygoïdeus in de figuur rechts minder juist aangegeven.

\section{PLAAT II.}

Fig. 5 en 6. Horizontale doorsneden door een larve ${ }^{1)}$ van 4.5 m.M. (serie 2). Vergrooting $35 \times$. Halfschematisch.

Ligging van het laatste, gedeeltelijk ontwikkelde kopmyotoom -) en eerste rompmyotoom ten aanzien van het gehoorblaasje, den N. X en de arteria occipito-vertebralis.

Fig. 7 en 8. Horizontale doorsneden door een larve van 5 m.M. (serie 3). Vergrooting $35 \times$. Halfschematisch.

Ligging der kop- en rompmyotomen als in figuur 5 en 6.

Fig. 9. Horizontale doorsnede door een larve van 5 m.M. (serie 5), Vergrooting $35 \times$. Halfschematisch.

Ligging van het occipitaalboogproton ten opzichte van het eerste rompmyotoom, dat in reductie is. Het ganglion bij het tweede rompmyotoom is goed ontwikkeld.

1) Daar het materiaal mij gefixeerd ter hand werd gesteld en voor de fixatie het eihulsel verwijderd werd, is het mij niet mogelijk aan te geven bij welke lichaamslengte het eihulsel verlaten wordt en dus de onderscheiding tusschen embryo en larve vol te houden. Er wordt hier dus steeds van larve gesproken, ook al zou embryo soms juister zijn.

2) In de figuren 5-14 zijn met K. S. II en R. S. 1, 2, 3 niet het laatste kopsegment en de drie eerste rompsegmenten bedoeld, maar de daarmede correspondeerende gedeeltelijk of geheel ontwikkelde myotomen. Kortheidshalve werd deze notatie, die ook in de beschrijving gebruikt werd, ingevoerd. 
Fig. 10. Horizontale doorsnede door dezelfde larve meer ventraal getroffen. Vergrooting $35 \times$. Halfschematisch.

Ligging van het parachordaalplaat-proton, waarvan slechts het caudale deel in deze coupe te zien is, vóór het eerste rompmyotoom, dat voor een deel gereduceerd is. De oorsprong der art. occipito-vertebralis ligt meer caudaal dan in vorige series.

Fig. 11. Horizontale doorsnede door een larve van $6 \%$ m.M.(serie 7). Vergrooting $35 \times$. Halfschematisch.

Ligging van het gereduceerde rompmyotoom ten aanzien van het oorkapselproton. Verhouding zijwand en zijwandpijler.

Fig. 12. Horizontale doorsnede door dezelfde larve. Vergrooting $35 \times$. Halfschematisch.

Het planum basale is kraakbeenig en vóór de chordapunt tot het ongepaarde planum trabeculare vereenigd. Reductie van het eerste rompmyotoom. Aanhechting der oogspieren aan de trabekelverhevenheid. Kraakbeen fijn, zenuwweefsel wijd gestippeld.

Fig. 13. Horizontale doorsnede door een larve van $81 / 2 \mathrm{~m}$.M. (serie 12). Vergrooting $35 \times$. Halfschematisch.

Enkele spiervezels van het eerste rompmyotoom hechten zich aan het oorkapselkraakbeen.

Schema 1. Dit schema werd in aansluiting bij den tekst op pag. 22 seq. ontworpen ter verduidelijking van de ligging van de basaalplaat en den occipitaalboog ten aanzien van kop-en rompsegmenten en de reductie der bijbehoorende myotomen en ganglia.

Door rechthoeken zijn de somieten aangegeven, die al of niet myotomen ontwikkelen. In het eerste geval zijn ze gearceerd. De gedeeltelijke stippeling der rechthoeken in schema a en b duidt op een rangschikking der mesenchymkernen. De reductie van het myotoom, bij het eerste rompsegment (R. S. 1) behoorend, is door het weglaten der horizontale streping duidelijk gemaakt.

Ganglia zijn door verticaal gearceerde cirkels, dorsale en ventrale zenuwwortels door boven elkaar geplaatste 
stippen aangeduid. Occpitaalboog en wervelbogen worden door verticale lijnen tusschen de segmenten voorgesteld en evenzoo de basaalplaat door een horizontale lijn. Voorkraakbeen is gestippeld. In schema b, waar het mesenchym der toekomstige parachordaalplaat nog onduidelijk gerangschikt is, is dit door een stippellijn uitgedrukt.

Schema 2. Vergelijklng der ligging van den occipitaalboog der Urodelen met dien der Anuren (volwassen toestand).

Het schema der Urodelen werd gecombineerd uit hetgeen bij Necturus (Miss Platt, 1897) en Amblystoma (Goodrich, 1911, wordt gevonden. Voor Necturus late men in segment 5 den dorsalen wortel van den $\mathrm{N}$. spinalis 2 weg; voor Amblystoma denke men myotoom 3 ventraal gereduceerd. De korte verticale lijn tusschen segment 2 en 3 stelt den praeoccipitaalboog voor. De aanduiding der zenuwen geschicdde, zooals die voor Urodelen geldt; $\mathrm{X}_{1}$ is de occipitale zenuw.

Het schema der Anuren is hetzelfde als schema if van Alytes: voor de aanduiding der zenuwen zie schema 1.

\section{PLAAT III.}

Fig. 14. Horizontale doorsnede door een larve van $29 \mathrm{~m} . \mathrm{M}$. (serie 18) ter hoogte van de occipito-vertebraalstreek. Vergrooting $38 \times$.

Ligging van den tweeden wervel tegenover het myoseptum tusschen het tweede en derde rompmyotoom. De N.-spinalis 2 begeeft zich tusschen den eersten en tweeden wervel naar buiten.

Fig. $16 \mathrm{a}-\mathrm{h}$. Dwarse doorsneden door een larve van 53 m.M. (serie 19), beginnend ter hoogte van het tectum synoticum en in rostrale richting elkander opvolgend. Vergrooting $13 \times$.

Geschematiseerde figuren ter verduidelijking van het facialisverloop. Voor verklaring zie pg. 70 en 71.

Fig. 17 a en b. Dwarse doorsnede door het oorkapsel van een larve van 25 m.M. (serie 17) en van een larve van 53 m.M.; 
deze laatste komt overeen met fig. 16f. Vergrooting $28 X$ resp. 15

Vorming van het facialis-kanaal binnen het oorkapsel. Het nieuwgevormde kraakbeenwandje is in fig. $17 \mathrm{~b}$ niet gelijk het overige kraakbeen gestippeld. Eenigszins schematisch.

Fig. 18. Dwarse doorsnede ter hoogte van de cupula anterior en de basaalplaat van een larve van $16 \mathrm{~m} . \mathrm{M}$. (serie 15). Geschematiseerd. Vergrooting $45 X$.

Ligging van den ganglionair-verdikten $\mathrm{N}$. facialis tusschen basaalplaat en oorkapsel. Door vereeniging van deze beide volgens de stippellijnen kan men zich de vorming van het extracapsulaire kanaaldeel denken.

Fig. 19 a en b. Dwarse doorsnede door het oorkapsel van een larve van $16 \mathrm{~m} . \mathrm{M}$. (serie 15). Vergrooting $50 \times$.

Aanleg van den wand, die het for. perilymphaticum int. caudaal begrenst. In $\mathrm{b}$ is de ligging van het toekomstig for. perilymphaticum ext. gegeven.

Fig. 20 a en b. Dwarse doorsneden door het oorkapsel van een larve van $22 \mathrm{~m} . \mathrm{M}$. (serie 16), ongeveer terzelfder hoogte als fig. 19 a en $b$ genomen. Vergrooting $95 \times$.

De wand, caudaal van het for. perilymphaticum internum, is nu kraakbeenig. Het jonge kraakbeen is aan de geringe afmeting der kraakbeencellen herkenbaar. In $b$ is de ligging van het for. perilymphaticum ext. met den saccus perilymphaticus duidelijk.

Fig. $21 \mathrm{a}-\mathrm{h}$. Schematische afbeeldingen tot vergelijking van de suprarostralia der volgende Anuren:

a. Rana fusca; b. Nototrema marsupiatum; c. Calyptocephalus Gayi; d. Alytes obstetricans; e. Pelobates fuscus; f. Bufo lentiginosus; g. Cyclorhamphus culeus; h. Leptodactylus (ocellatus?).

De tweede rij geeft de suprarostralia met bewegelijk vleugeldeel. De trabekelhoorns zijn gearceerd en de vergelijkbare vleugeldeelen gestippeld. In a is het foramen pro art. palatina aangegeven; in d de ligging van de ongepaarde, mediane art. palatina. Fig. a en $d$ naar Peeters 
(1910); fig. b, c, f, $g$ en $h$ naar Parker (1881); fig. e naar Dugès (1834) en Schulze (1892).

\section{PLAAT IV.}

Fig. 15. Dwarse doorsnede door een larve van $7 \mathrm{~m} . M$. (serie 8) ter hoogte van de aanhechting van den processus ascendens aan den zijwand. Vergrooting $100 \times$.

Fig. 22. Dwarse doorsnede door een larve van 53 m.M. (serie 19) ter hoogte van de commissura quadrato-cranialis anterior. Vergrooting $30 \times$.

Begin der kanaalvorming voor den $\mathrm{R}$. internus narium. Het dak is nog vliezig. Door de dichtere stippe'ing is de ligging van den oorspronkelijken zijwand aangegeven.

Fig. 23. Dwarse doorsnede door een larve van $25 \mathrm{~m}$. M. (serie 17) ter hoogte van den processus lateralis van den trabekelhoorn. Vergrooting $40 \times$.

Aanhechting der admandibularia aan het kraakbeen van Meckel. Rechts vindt men den goed ontwikkelden R. palatinus der arteria carotis, links een uiterst dun takje van den linker' R. palatinus. * Aanhechting van den musculus temporalis en den musculus masseter (dorsale spiergroep) aan het Meckel's kraakbeen. **' Juist aangesneden infrarostralia.

Fig. 24 a-c. Dwarse doorsneden door een larve van 16 m.M. (serie 15; a ligt het meest rostraal, c ter hoogte van den voorrand der hersenen, $\mathrm{b}$ tusschen beide in. Vergrooting $45 X$.

Aanleg praecerebraalplaat; het kraakbeen is in b nog slechts zeer $z$ wak ontwikkeld, in a en c in aansluiting bij den trabekelhoorn en de internasaalplaat goed waar te nemen. De linker R. palatinus der art. carotis is in c nog duidelijk, doch geringer ontwikkeld dan de rechtertak en heeft zich in a in een aantal fijne takjes opgelost. Het reukorgaan is gearceerd.

Fig. 25. Dwarse doorsnede door een larve van $25 \mathrm{~m} . \mathrm{M}$. (serie 17) ter hoogte van den processus muscularis. Geschematiseerd. Vergrooting $30 \mathrm{X}$.

Relatieve ligging der spieren van het kauwtoestel en het hyoid. 


\section{Afkortingen.}

A. car. i. = Arteria carotis interna.

A. occ.-v. = Arteria occipito-vertebralis.

Adm. $\quad=$ Admandibulare.

Arc. occ. = Arcus occipitalis.

C. aud. = Capsula auditiva.

C. M. = Cartilago Meckeli.

C. N. = Cavum nasi.

C. occ. - Crista occipitalis lateralis.

C.qu.cr.a. = Commissura quadrato-cranialis anterior.

Ch. d. - Chorda dorsalis.

Co. Tr. - Cornu trabeculae.

Cr. ma. = Crista marginalis.

F. ac. a. = Foramen acusticum anterius.

F. ac. p. = Foramen acusticum posterius.

F. car. = Foramen caroticum.

F. cr. pal. = Foramen cranio palatinum.

F. jug. = Foramen jugulare.

F. ov. = Fenestra ovalis.

F. ov. pr. = Fenestra ovalis primaria.

F. pr. $\quad$ Foramen proöticum.

G. V, X. = Ganglion V, X.

G. B. = Gehoorblaasje.

G. pr. = Ganglion proöticum

G. R.S. 2 = Ganglion behoorend bij het tweede rompsegment.

G.Sp. 2,3,4- Ganglion spinale 2, 3, 4.

Hy. $\quad$ Hyoid.

I. A. = Intersegmentaalarterie.

Infrar. $=$ Infrarostrale.

K. S. II. = Kopsegment II (resp. myotoomaanleg behoorend bij kopsegment II).

L. q.-e. - Ligamentum quadrato-ethmoidale. 
L. W. = Laterale wandlijst.

Lag. = Lagena.

M. d. c. h. = Musculus depressor cartilaginis hyoideae.

M.d.m. $a_{1}=$ Musculus depressor mandibulae anterior (origo quadratum).

M.d. m. $a_{2}=$ Musculus depressor mandibulae anterior (origo hyoid).

M.d.m.p. = Musculus depressor mandibulae posterior.

M. g.-h. = Musculus genio-hyoideus.

M. $\mathrm{m}_{1}=$ Musculus masseter? (origo dorsaal aan de binnenzijde van den processus muscularis!

M. $\mathrm{m}_{2}=$ Musculus masseter (origo ventraal aan de binnenzijde van den processus muscularis).

M. o. = Musculi oculi.

M. pt. = Musculus pterygoïdeus.

M. st. $=$ Musculus subtemporalis.

M. t. = Musculus temporalis.

N. IX, X. = Nervus IX, X.

N. a.-f. = Nervus acustico-facialis.

N. sp. 2. = Nervus spinalis 2 .

O. K. = Oorkapselkraakbeen.

O. P. = Oorkapselproton.

Oc. $=$ Oculus.

Occ. P. $=$ Occipitaalboog-proton.

P. bas. = Pars basilaris.

P. K. = Parachordaalkraakbeen,

P. P. = Parachordaalplaat-proton.

P. q. = Palatoquadratum.

Pl. bas. = Planum basale.

P1. T. = Planum trabeculare.

Pr. a. $=$ Processus antorbitalis

Pr. asc. $=$ Processus ascendens.

Pr. cp. = Praecerebraalplaat.

Pr. lat. = Processus lateralis.

Pr. musc. $=$ Processus muscularis.

Pr.ps.-pt. $=$ Processus pseudo-pterygoïdeus.

Pr.q.ethm. $=$ Processus quadrato-ethmoïdalis.

R.int. nar. = Ramus internus narium der arteria orbito-nasalis. 
R. pal. = Ramus palatinus der arteria carotis interna.

R.S. 1, 2, $3=$ Rompsegment 1, 2, 3. (resp. myotomen, behoorend bij genoemde rompsegmenten).

Rec. p. $b .=$ Recessus partis basilaris.

S. per. $=$ Saccus perilymphaticus.

Sp. $1,2,3=$ Spinale zenuw 1, 2, 3 .

Sp. m. = Spatium meningeale.

Supr. $=$ Suprarostrale.

T. syn. = Tectum synoticum.

T. V. = Trabelhoornverhevenheid.

Tel. $=$ Telencephalon.

Tr. $=$ Trabecula.

V. J. = Vena jugularis.

V. K. = Ventraal kraakbeen, dat de cornua verbindt.

W. = Wand, caudaal van het for. perilymphaticum int.

W. $1,2,3=$ Wervel 1, 2, 3 .

W. a. = Wandaanleg, caudaal van het for. perilymphaticum int.

Zw. $=$ Zijwand.

$Z_{w} . K .=Z_{i j w a n d k r a a k b e e n}$

$Z_{w}$. P. $=Z_{\text {ijwandpijler. }}$

I. $\quad=$ Nervus olfactorius.

II. $\quad=$ Nervus opticus.

V. $\quad=$ Nervus trigeminus.

$\mathrm{V}_{1} \quad=$ Ramus orbito-nasalis $\mathrm{V}$.

$\mathrm{V}_{1 \mathrm{a}} \quad=$ Ramus internus narium $\mathrm{V}$.

$\mathrm{V}_{1 \mathrm{~b}} \quad=$ Ramus externus narium $\mathrm{V}$.

$\mathrm{V}_{2} \quad=$ Ramus maxillo-mandibularis $\mathrm{V}$.

$\mathrm{V}_{2 \mathrm{a}}=$ Ramus maxillaris superior.

$\mathrm{V}_{\text {gh }}=$ Ramus maxillaris inferior (mandibularis) $\mathrm{V}$.

VII. $=$ Nervus facialis,

VII $=$ Ramus palatinus VII.

$\mathrm{VII}_{2 .}=$ Ramus hyomandibularis VII.

VII $\mathrm{d}=$ Dorsale wortel van den N. facialis.

VIII. $=$ Nervus octavus.

IX. $=$ Nervus glossopharyngeus.

$\mathrm{X} . \quad$ Nervus vagus. 


\section{Inhoud.}

pg.

I. Inleiding . . . . . . . . , . . 9

II. Materiaal en Techniek . . . , , . . . . . . 13

III. De eerste ontwikkeling van het Chondrocranium tot en met stadium I. . . . . , . . 18

A. Planum basale, Occipitaalboog, Chorda dorsalis . 18

B. Capsula auditiva . . . . . . . . , . . 48

C. Regio orbitalis. . . . . . . . . . . . 52

D. Regio ethmoïdalis, Suprarostralia . . . . 57

E. Palatoquadratum, Cartilago Meckeli, Infrarostralia 60

IV. De verdere ontwikkeling van het Chondrocranium vóór de metamorphose tot en met stadium II . . . 65

A. Planum basale, Occipitaalboog. Chorda dorsalis . 65

B. Capsula auditiva, Tectum posterius. . . . . 69

C. Operculum en Plectrum . . , . . . . . 86

D. Regio orbitalis. . . . . . . . . . . 93

E. Regio ethmoïdalis, Suprarostralia . . . . . . 103

F. Palatoquadratum, Cartilago Meckeli, Infrarostralia 111

V. Overzicht der verkregen uitkomsten . . . . . . 121

Literatuur. . . . . . . . . . . . 129

Verklaring der figuren . . . . . . . . . . . 134

Lijst van afkortingen. . . . . . . . . 140 


\section{Addendum.}

Aan noot ${ }^{1}$ ) pag. 22 voege men toe: Kortheidshalve worden in de seriebeschrijving en elders de geheel of gedeeltelijk ontwikkelde myotomen, bij genoemde segmenten behoorend, eveneens met K. S. II en R. S. 1, 2 en 3 aangeduid.

\section{Corrigenda}

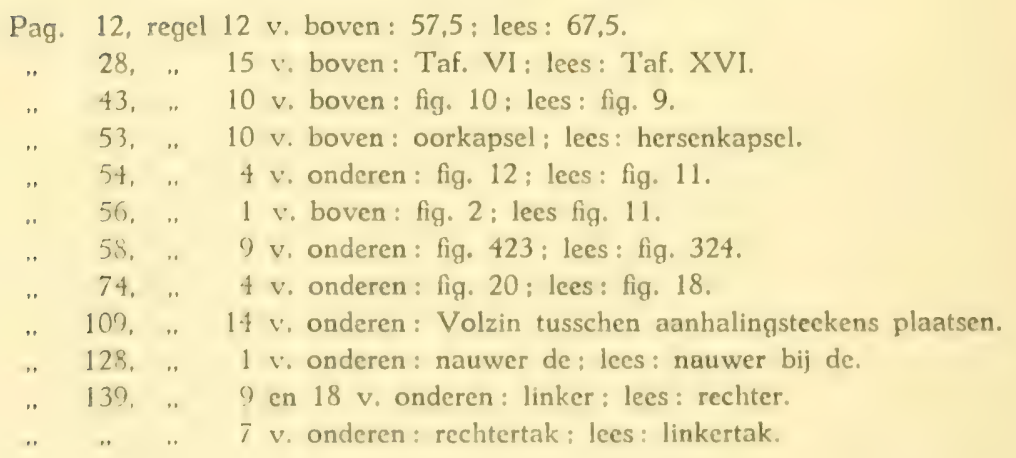


STELLINGEN 


\section{I}

De basaalplaat der Anuren bestaat uit twee componenten: trabekelplaat en occipitaalplaat.

\section{II}

De suprarostralia van Rana fusca laten zich niet op de door Peeters aangegeven wijze van die van Alytes obstetricans afleiden.

III

De „columella" der Amphibiën is een derivaat van den hyoidboog.

IV

De voortbeweging der zoogdiereieren in den eileider is nier aan het wimperepitheal, maar aan spiercontracties der tuba te danken.

(Sobotta, Anat. Hefte, 1916.)

\section{$\mathrm{V}$}

De eerste wervel van Pipa americana is een dubbelwervel.

\section{VI}

Haren zijn organen sui generis.

(Botezat, Anat. Anz., 1914.)

\section{VIl}

Men mag bij vele homoiotherme dieren lichaamsvergrooting (-verkleining), gepaard gaancie met relatieve oppervlakverkleining (-vergrooting), als aanpassing aan het leven in koude (warme) streken beschouwen.

(Theorie van Bergmann: v. Boatticher, Zoöl. Jahrb. 1917.) 


\section{VIII}

Weismann's principe der parallelinduktie laat zich niet vereenigen met zijn hypothese der geinduceerde "Germinal-Selektion".

\section{IX}

Ten onrechte meent Hartmann, dat het schema der generatiewis seling "nur mit $Z$ wang und in voller Verdrehung des Ausdrucks Generation und Generationswechsel auf die meisten Algen und Pilze übertragen werden kann".

(Die Kultur der Gzgenwart, Alg. Biologie, 1915 ; pag. 293.)

$$
\mathrm{X}
$$

De Coniferen zijn van de Cordaïtales, niet van de Lycopodiales af te leiden.

(Scott, Studies in Fossil Botany, 1909.)

\section{XI}

Phototropische prikkelgeleiding is als een diffusieverschijnsel op te vatten.

(Paál, Jahrb. f. Wiss. Bot., 1918.)

\section{XII}

De breede en smalle kelkvorm, die bij Calceola sandalina Lam. in den Eifel optreden, worden door Richter ten onrechte als mutaties (Calceola Sandalina Lam. n. mut. lata en alta) onderscheiden.

(Richter, Neues Jahrb. f. Mineralogie etc. 1916.)

\section{XIII}

De vlieghuidvinger der Pterosauriërs is met den vierden, niet met den vijfden vinger der Reptielenhand gelijk te stellen. 

PI. I.

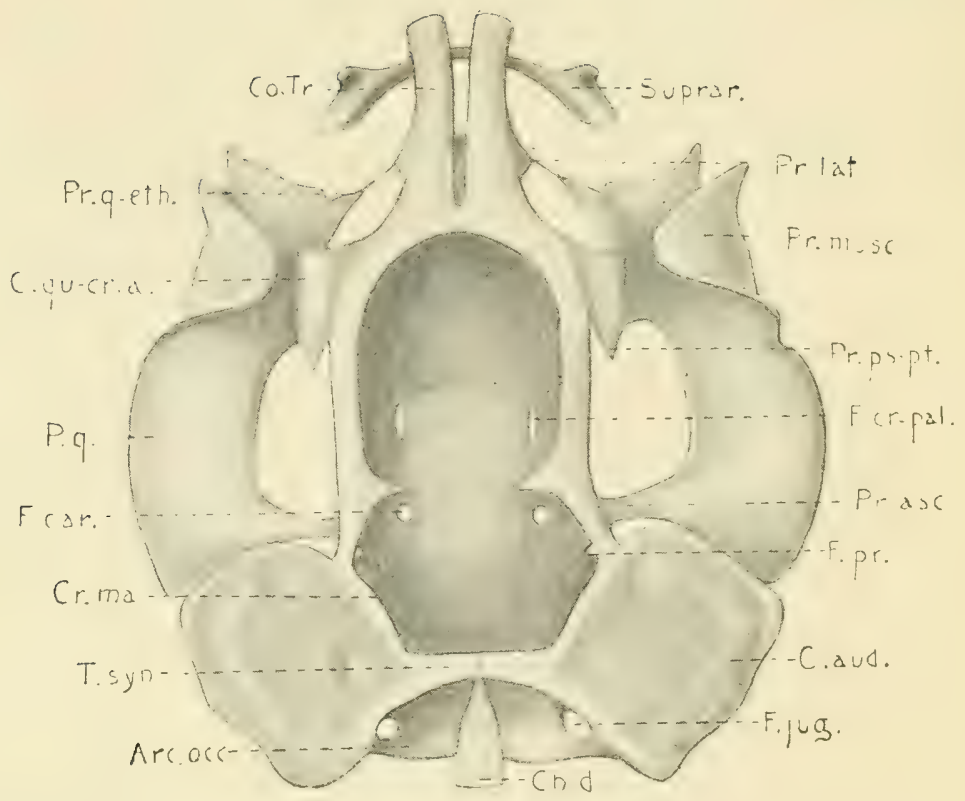

Fig. 3.

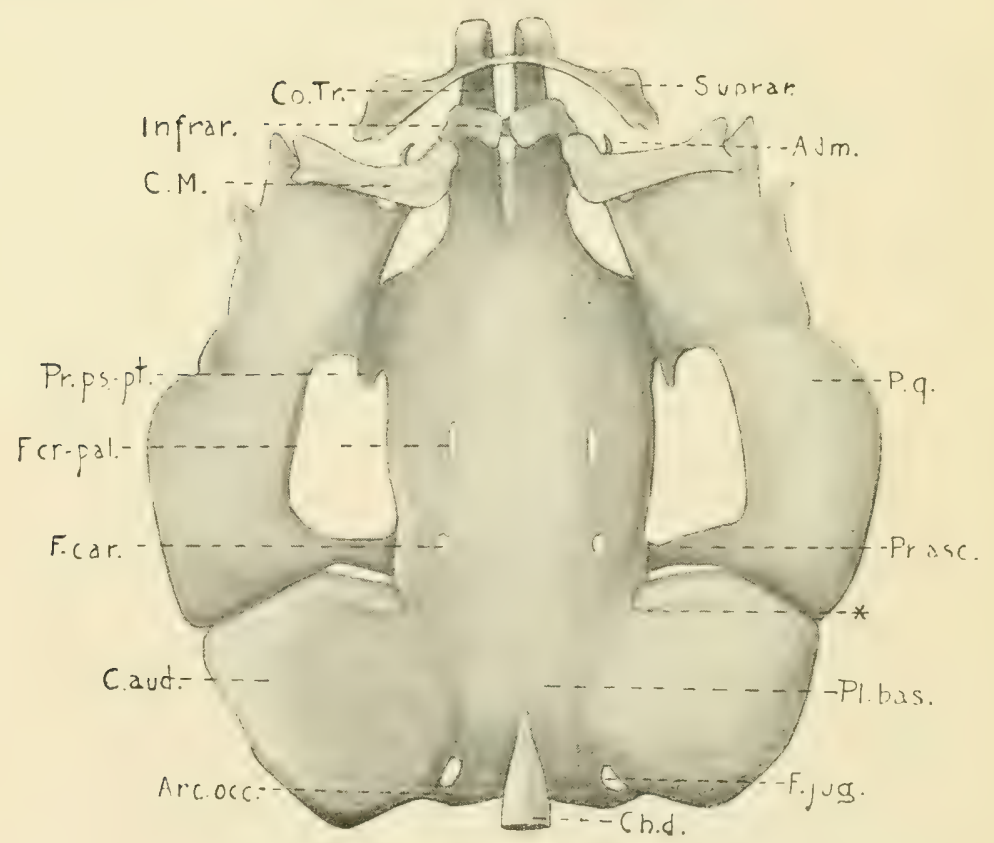

Fig. 4 . 


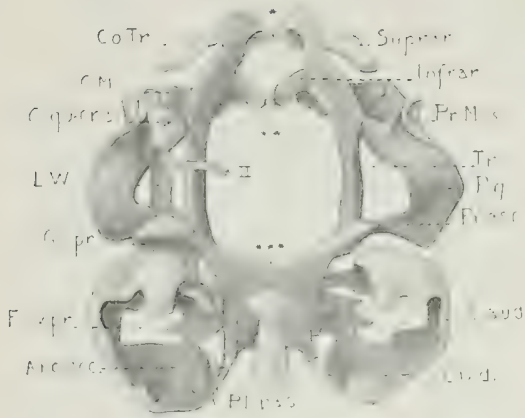

Fig. 1

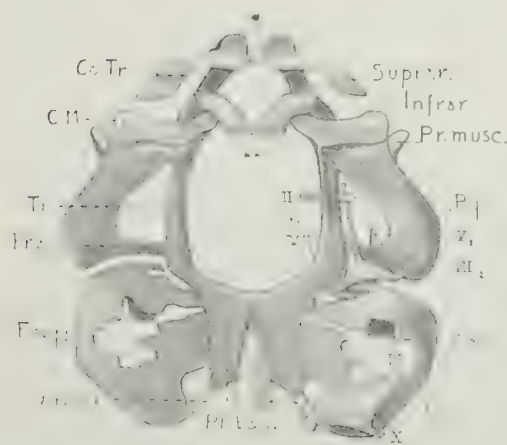

Van Seters del.
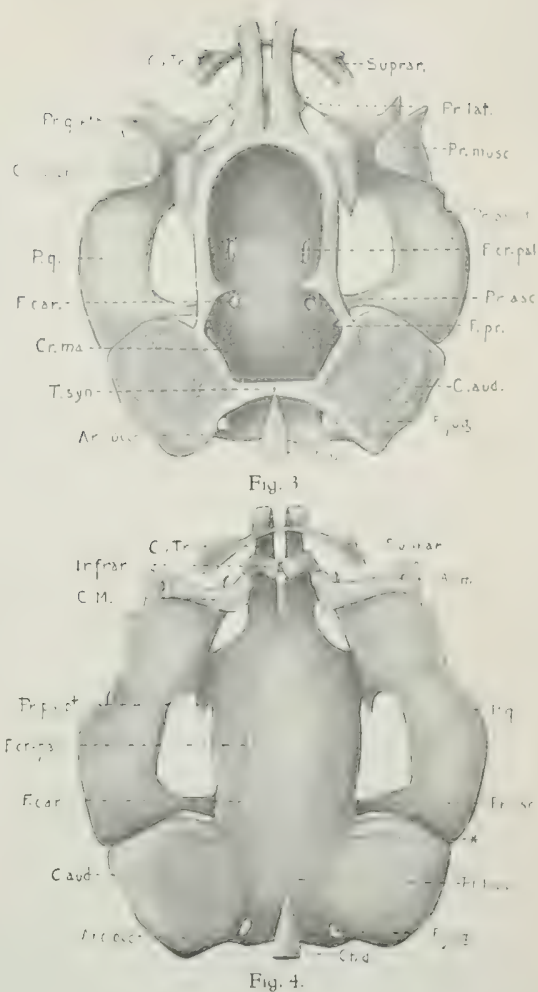
Pl. II.

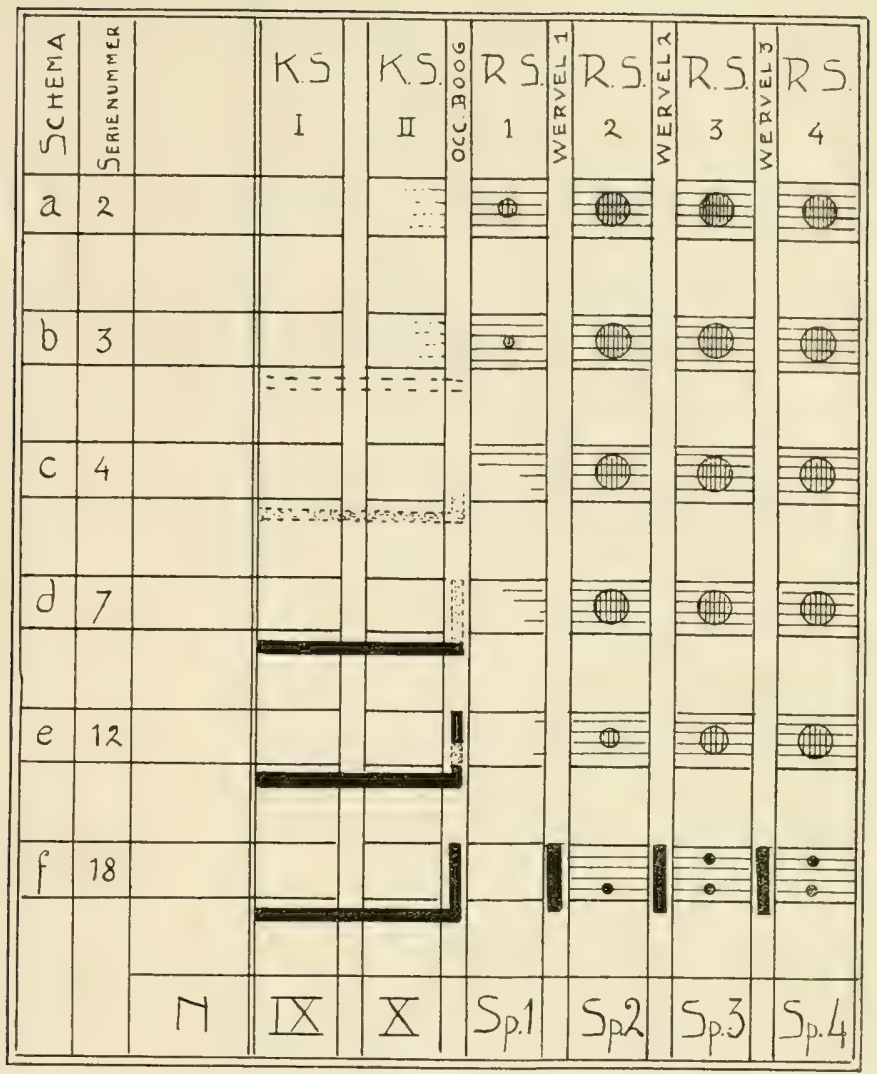

Schema 1.

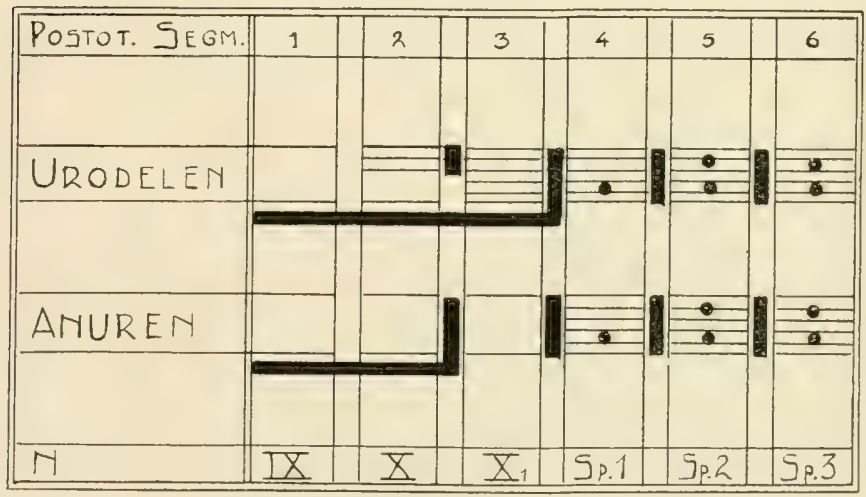

Schema 2. 

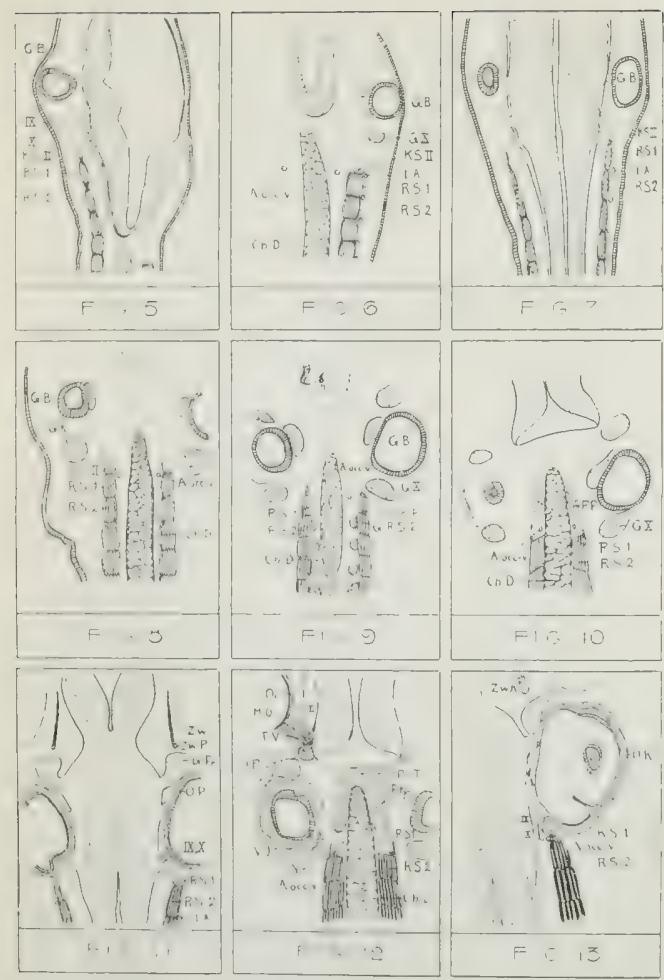

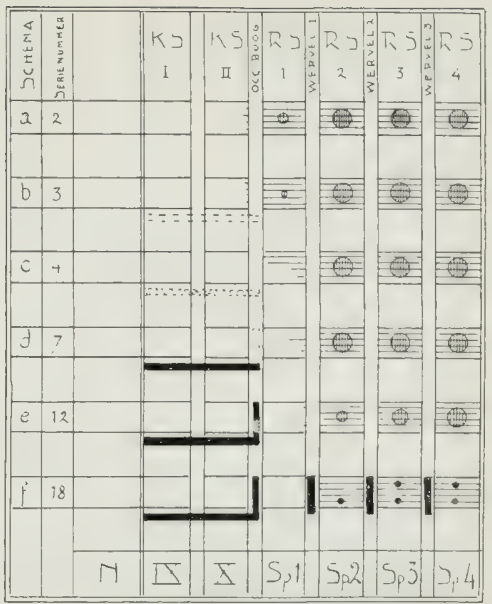

Schema 1.

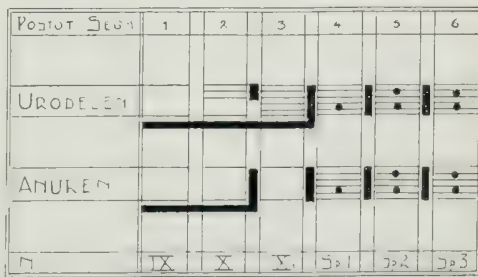

Schema 2. 

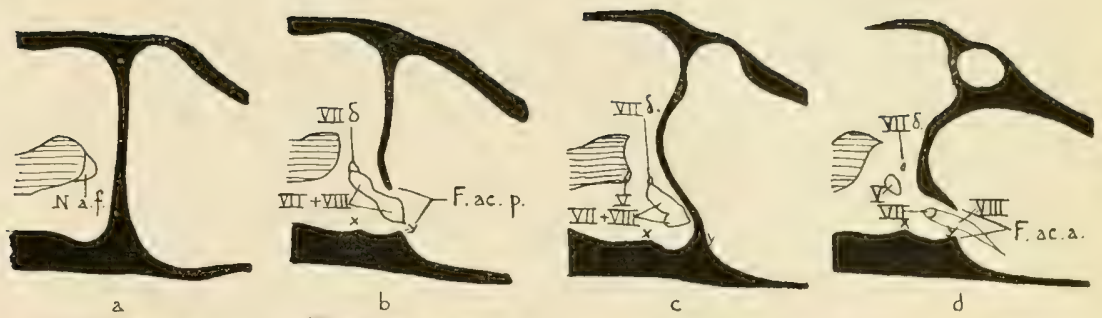

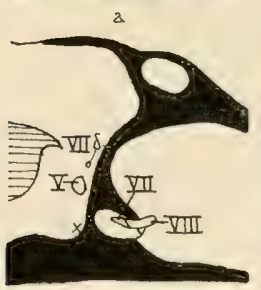

e

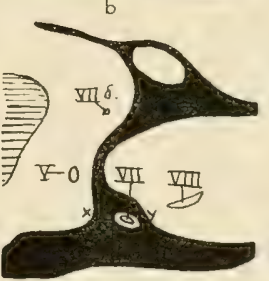

f

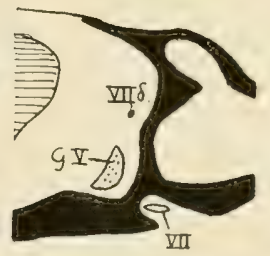

g

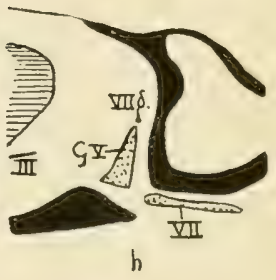

Fig. 16.

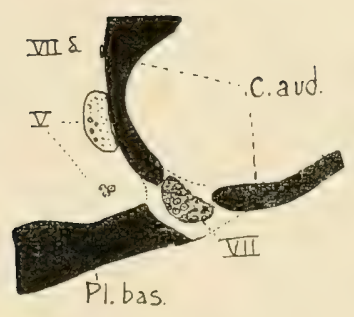

Fig. 18.

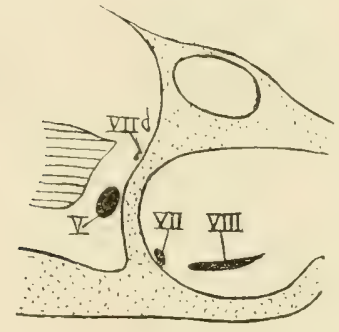

Fig. 17a.

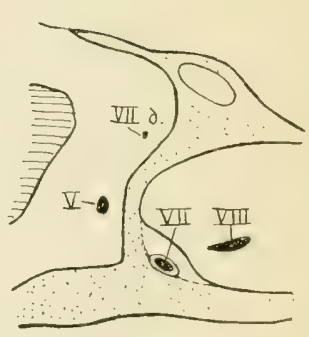

Fig. 17b.

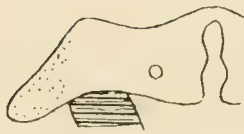

a

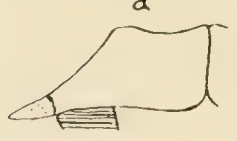

e

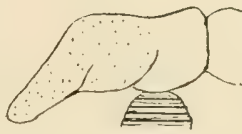

$b$

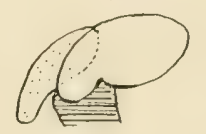

f

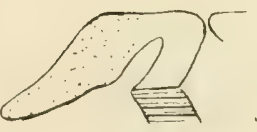

c.

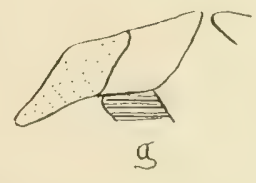

Fig. 21.
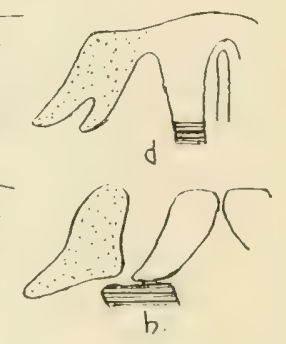


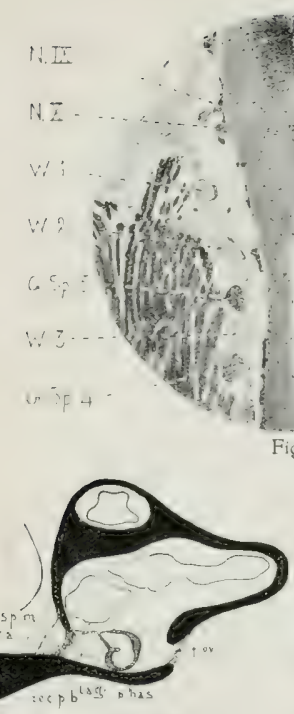

Fig. 19a

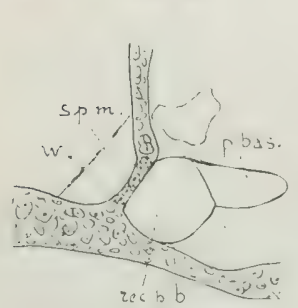

Fig. 20a
Van Seters del. $c$ aud

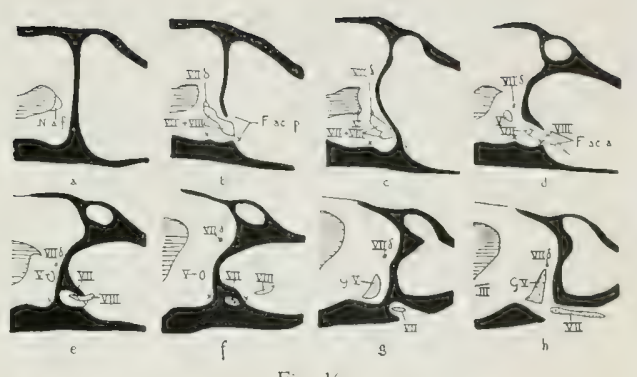

Fig. 10.

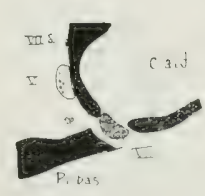

Fig. 18

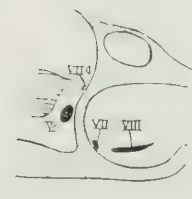

Fig̣. 17a

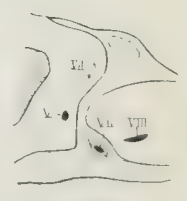

Fic. $17 \mathrm{~b}$
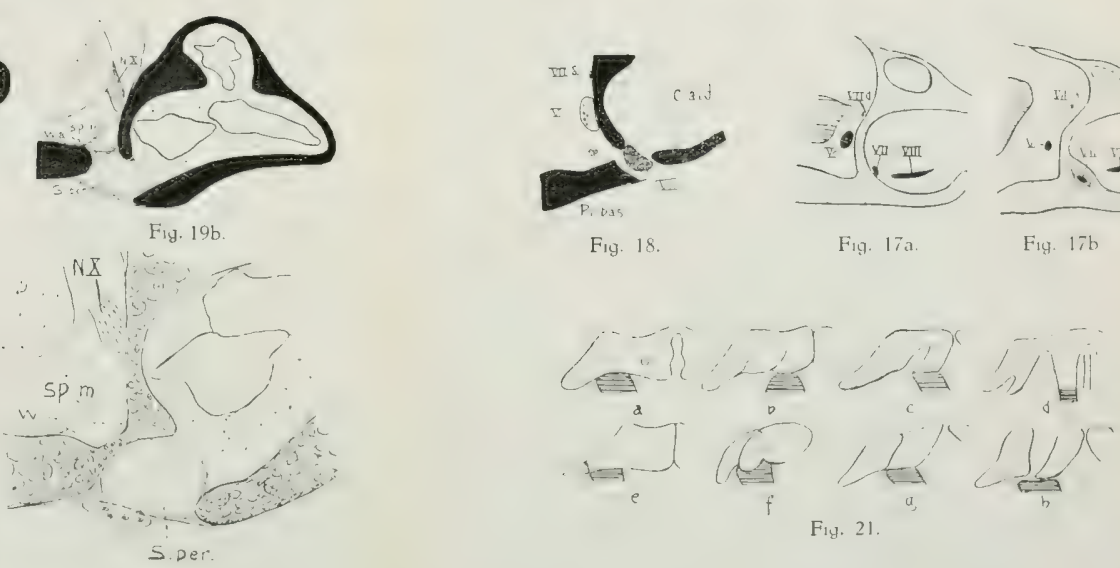

[ity. 20 b. 



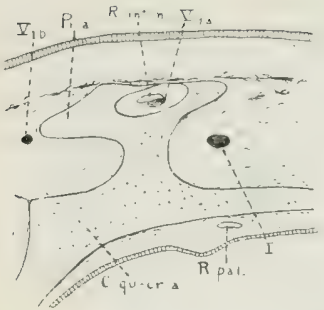

Fig. 22

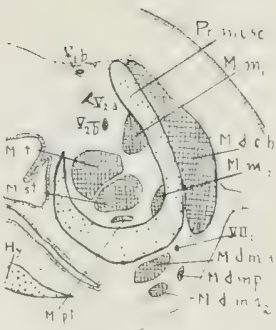

F. 25

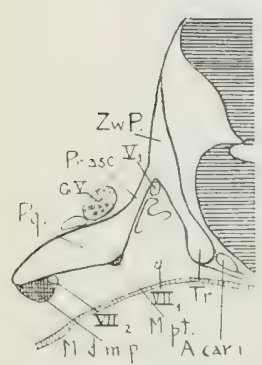

Fiy. 15

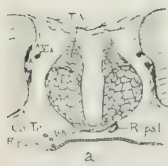

Van Seters del.

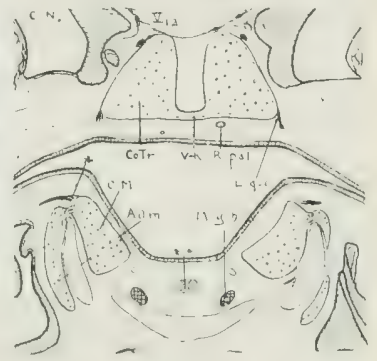

$\mathrm{F}: 23$

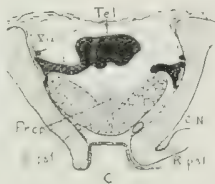

Fiy. 24 . 





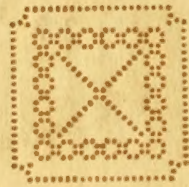

